\title{
GROUND-WATER QUALITY AND GEOCHEMISTRY IN DAYTON, STAGECOACH, AND CHURCHILL VALLEYS, WESTERN NEVADA
}

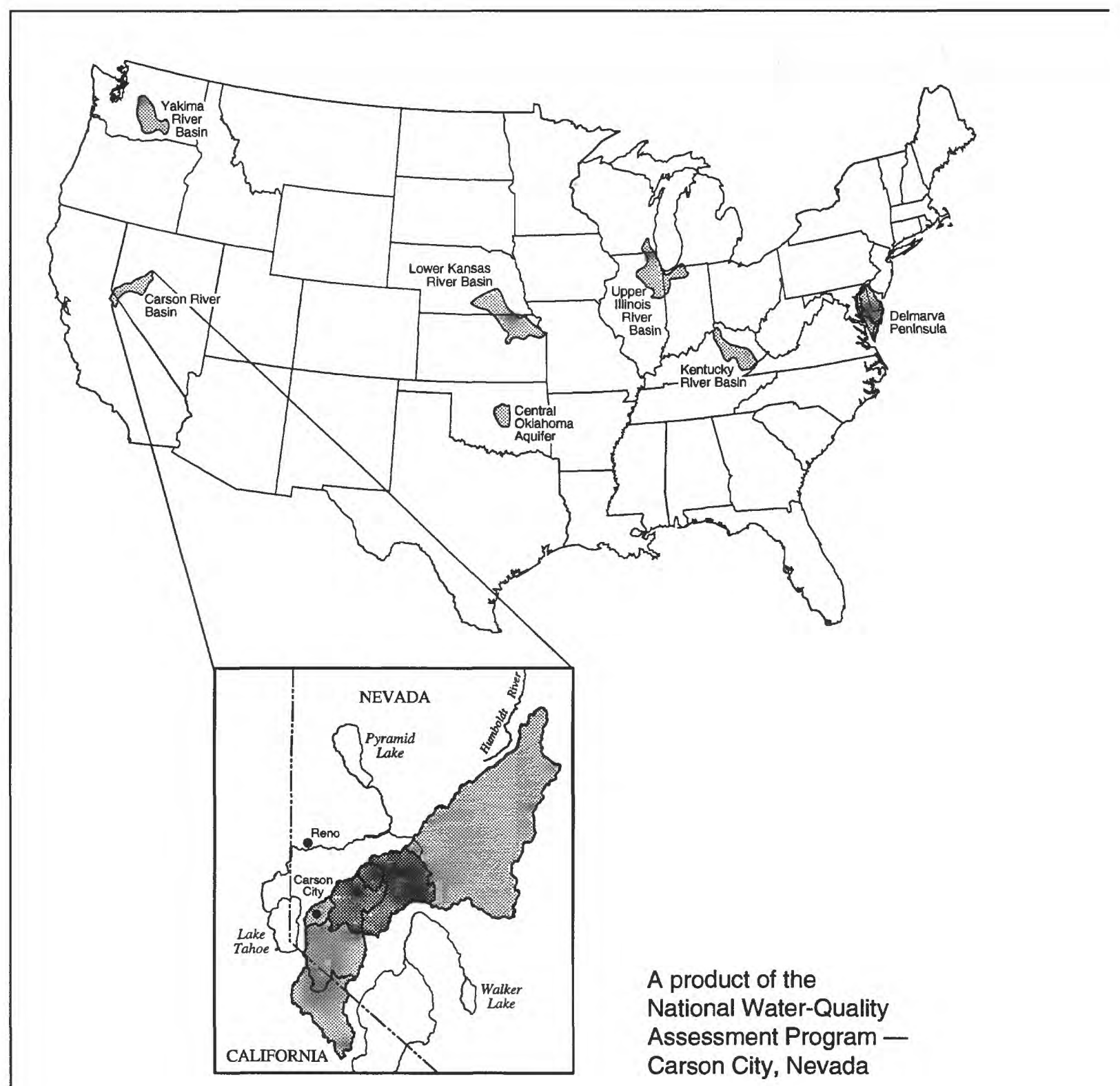

UNITED STATES GEOLOGICAL SURVEY

Open-File Report 93-356 


\section{FOREWORD}

One of the great challenges faced by water-resources scientists is providing reliable water-quality information to guide the management and protection of the Nation's water resources. That challenge is being addressed by Federal, State, interstate, and local water-resources agencies and by academic institutions. Many of these organizations are collecting water-quality data for a host of purposes, including compliance with permits and water-supply standards; development of remediation plans for specific contamination problems; operational decisions on industrial, wastewater, or water-supply facilities; and research to advance our understanding of water-quality processes. In fact, during the past two decades, tens of billions of dollars have been spent on water-quality data-collection programs. Unfortunately, the utility of these data for present and future regional and national assessments is limited by such factors as the areal extent of the sampling network, the frequency of sample collection, the varied collection and analytical procedures, and the types of water-quality characteristics determined.

To address this deficiency, the Congress appropriated funds for the U.S. Geological Survey, beginning in 1986, to test and refine concepts for a National Water-Quality Assessment (NAWQA) Program that, if fully implemented, would:

1. Provide a nationally consistent description of water-quality conditions for a large part of the Nation's water resources;

2. Define long-term trends (or lack of trends) in water quality; and

3. Identify, describe, and explain, as possible, the major factors that affect observed water-quality conditions and trends.

As presently envisioned, a full-scale NAWQA Program would be accomplished through investigations of a large set of major river basins and aquifer systems that are distributed throughout the Nation and that account for a large percentage of the Nation's population and freshwater use. Each investigation would be conducted by a small team that is familiar with the river basin or aquifer system. Thus, the investigations would take full advantage of the region-specific knowledge of persons in the areas under study.

Four surface-water projects and three ground-water projects are being conducted as part of the pilot program to test and refine the assessment methods and to help determine the need for and the feasibility of a full-scale program. An initial activity of each pilot project is to compile, screen, and interpret available data to provide an initial description of water-quality conditions and trends in the study area. The results of this analysis of available data are presented in individual reports for each project.

The pilot studies depend heavily on cooperation and information from naany Federal, State, interstate, and local agencies. The assistance and suggestions of all are gratefully acknowledged.

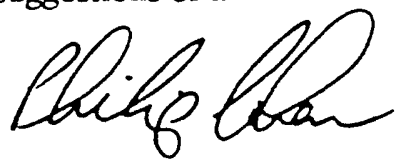

Philip Cohen Chief Hydrologist 


\title{
Ground-Water Quality and Geochemistry in Dayton, Stagecoach, and Churchill Valleys, Western Nevada
}

\author{
By James M. Thomas and Stephen J. Lawrence
}

U.S. GEOLOGICAL SURVEY

Open-File Report 93-356

A product of the

National Water-Quality

Assessment Program-

Carson River Basin, Nevada

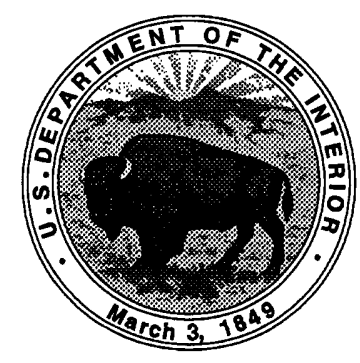

Carson City, Nevada 1994 


\title{
U.S. DEPARTMENT OF THE INTERIOR BRUCE BABBITT, Secretary
}

\author{
U.S. GEOLOGICAL SURVEY \\ GORDON P. EATON, Director
}

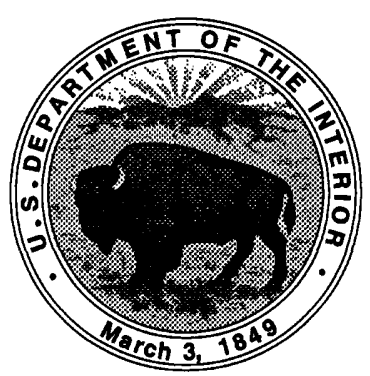

Any use of trade names in this publication is for descriptive purposes only and does not imply endorsement by the U.S. Government.

For additional information write to:

District Chief

U.S. Geological Survey 333 West Nye Lane, Room 203 Carson City, NV 89706-0866
Copies of this report can be purchased from:

U.S. Geological Survey Earth Science Information Center Open-File Reports Section Box 25286, MS 517 Denver Federal Center Denver, CO 80225-0046 


\section{CONTENTS}

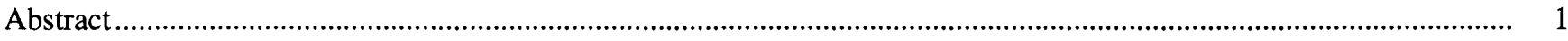

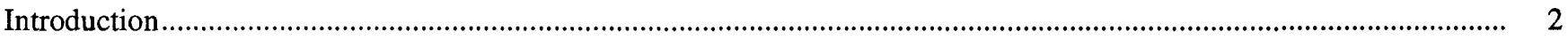

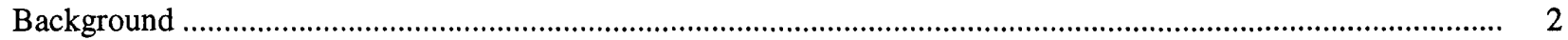

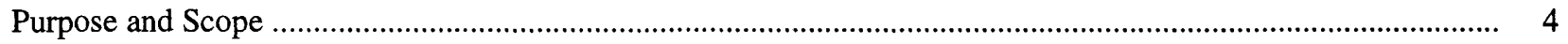

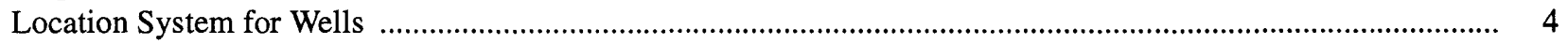

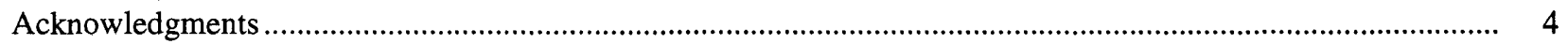

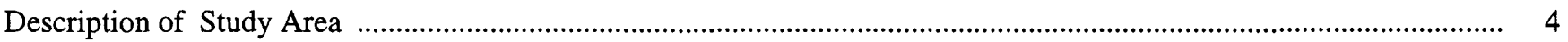

Location and Physiography .......................................................................................................................... 4

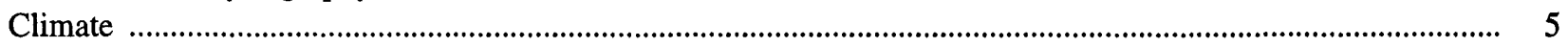

Land and Water Use ………………………………………………………………………………… 5

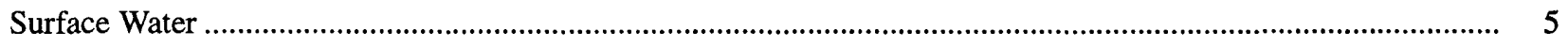

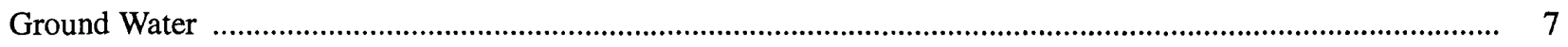

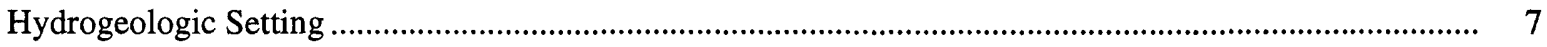

Mineralogic Composition of the Basin-Fill Sediments ................................................................... 10

Occurrence and Movement of Ground Water and Isotope Hydrology............................................. 11

Water Quality and Aqueous Geochemistry ……………………………………………………………………….... 18

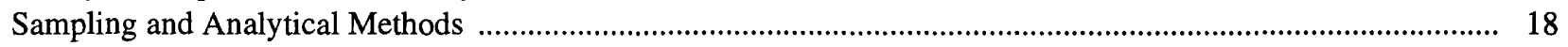

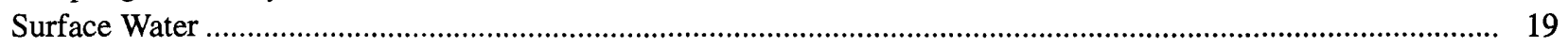

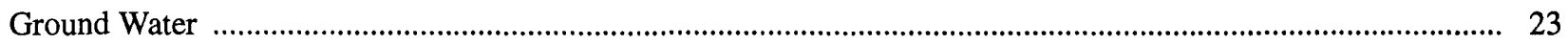

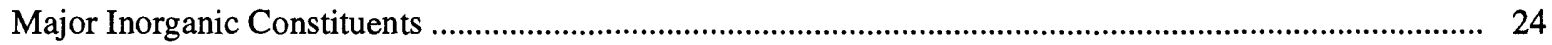

Modeling of Geochemical Reactions ......................................................................................... 24

Evaluation of Geochemical Models Using Sulfur and Carbon Isotopes............................................. 33

Age Dating of Ground Water by Using Carbon Isotopes .................................................................... 44

Minor Inorganic Constituents .............................................................................................................. 47

Radionuclides ……………………………………………………………………………….. 54

Synthetic Organic Compounds ……………………………………………………………………….... 56

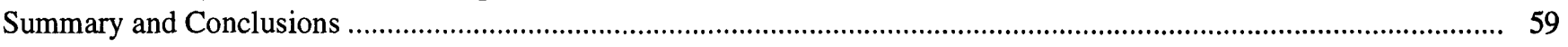

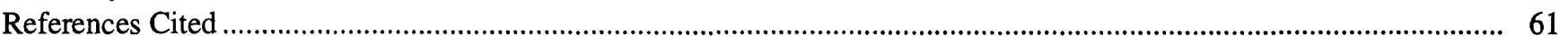

Appendix -Summary Statistics for the Ground-Water Quality of Dayton, Stagecoach, and Churchill Valleys .................. 65

\section{FIGURES}

1-3. Maps showing:

1. Location of the Dayton Valley and Churchill Valley hydrographic areas within the Carson River

Basin Pilot NAWQA study area.

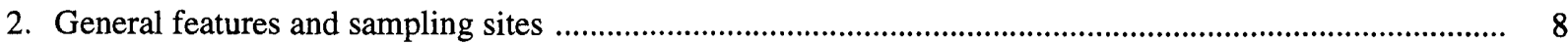

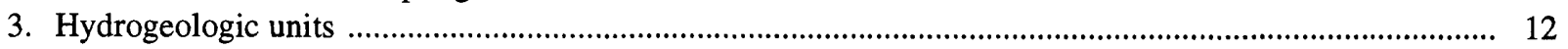

4. Graph showing relation of deuterium and oxygen-18 in water samples......................................................... 15

5-6. Maps showing isotope values for ground-water samples:

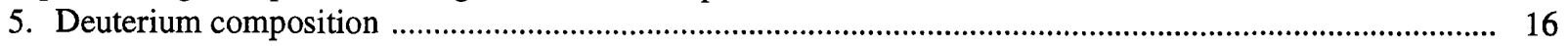

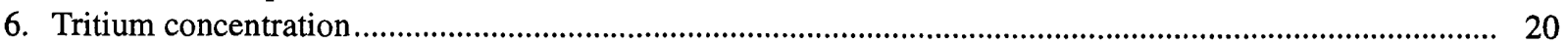

7. Boxplots showing major-ion and nutrient concentrations for water samples collected during low, medium, and high flows of the Carson River at Fort Churchill for calendar years 1980-90..................... 22

8. Plot showing the chemical composition of ground-water samples ................................................................. 25

9-10. Graphs showing median amounts of mass transfer for ground-water samples calculated by geochemical models:

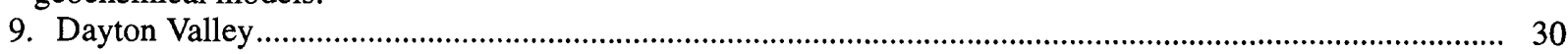

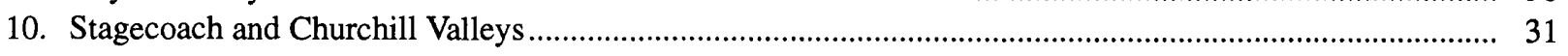


11-12. Graphs showing saturation indices for ground-water samples from the principal aquifers:

11. Calcite

12. Amorphous silica in Stagecoach and Churchill Valleys

13-14. Graphs showing relations between activities in ground-water samples:

13. Sodium and silica.

14. Calcium and sodium, calcium and potassium, and magnesium and potassium ......................................... 35

15. Graph showing relation between the concentration and isotope composition of dissolved sulfate in ground-water samples.

16. Map showing sulfur-34 composition of ground-water samples

17. Graph showing relation between the carbon-13 content of the dissolved inorganic carbon and the concentration of the dissolved inorganic carbon in ground-water samples

18. Map showing carbon-13 composition of dissolved inorganic carbon in ground-water samples

19-21. Graphs showing relations between constituents in ground-water samples:

19. Dissolved inorganic carbon and dissolved oxygen

20. Carbon-13 composition and carbon-14 activity of dissolved inorganic carbon

21. Deuterium and estimated carbon-14 ages

22-23. Maps showing concentrations in ground-water samples:

22. Iron

23. Manganese

24. Boxplots showing gross-alpha and gross-beta activities and radon-222 and uranium concentrations in ground-water samples

25-27. Graphs showing relations in ground-water samples:

25. Uranium concentration and gross-alpha activity

26. Potassium concentration and gross-beta activity

27. Uranium concentration and gross-beta activity corrected for the contribution of potassium- 40

\section{TABLES}

1. Sample site numbers and locations in Dayton, Stagecoach, and Churchill Valleys

2. Identification, abundance, and alteration of minerals in composite of five shallow-sediment samples .

3. Summary of major-ion and dissolved-solids concentrations measured in ground-water samples from Dayton, Stagecoach and Churchill Valleys, and their relation to Nevada State drinking-water standards...

4. Phases (minerals, gases, and cation exchange) and chemical compositions included in geochemical models of ground water for Dayton, Stagecoach, and Churchill Valleys

5. Major-ion ratios for ground-water samples affected by recharge from the Carson River .................................... 36

6. Estimated age of ground-water samples from principal aquifers of the study area........................................... 45

7. Summary of minor constituents concentrations measured in ground-water samples from the study area and their relation to Nevada State drinking-water standards

8. Summary of synthetic compounds measured in ground-water samples from the study area 


\section{CONVERSION FACTORS, ABBREVIATED WATER-QUALITY UNITS, AND VERTICAL DATUM}

\begin{tabular}{rll}
\hline Multiply & By & To obtain \\
\hline acre-foot (acre-ft) & 0.001233 & cubic hectometer \\
foot (ft) & 0.3048 & meter \\
inch (in.) & 25.40 & millimeter \\
mile (mi) & 1.609 & kilometer \\
\hline
\end{tabular}

Temperature: Degrees Celsius $\left({ }^{\circ} \mathrm{C}\right)$ may be converted to degrees Fahrenheit $\left({ }^{\circ} \mathrm{F}\right)$ by using the formula $\left.{ }^{\circ} \mathrm{F}=\left[1.8\left({ }^{\circ} \mathrm{C}\right)\right]+32\right]$.

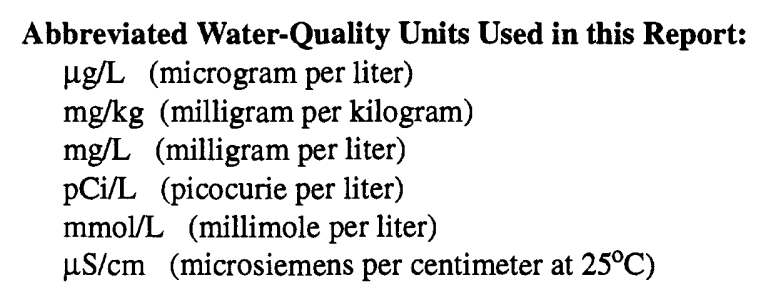

Sea Level: In this report, "sea level" refers to the National Geodetic Vertical Datum of 1929 (NGVD of 1929, formerly called "Sea-Level Datum of 1929") which is derived from a general adjustment of the first-order leveling networks of both the United States and Canada. 


\title{
Ground-Water Quality and Geochemistry in Dayton, Stagecoach, and Churchill Valleys, Western Nevada
}

\author{
By James M. Thomas and Stephen J. Lawrence
}

\section{Abstract}

The U.S. Geological Survey investigated the quality of ground water in the Dayton, Stagecoach, and Churchill Valleys as part of the Carson River Basin National Water-Quality Assessment (NAWQA) pilot study. Four aquifer systems have been delineated in the study area. Principal aquifers are unconsolidated deposits at altitudes of less than 4,900 feet above sea level and more than 50 feet below land surface. Shallow aquifers are at altitudes of less than 4,900 feet and are less than 50 feet below land surface. Upland aquifers are above 4,900 feet and provide recharge to the principal aquifers. Thermal aquifers, defined as those having a water temperature greater than 30 degrees Celsius, are also present. Ground water used in Dayton, Stagecoach, and Churchill Valleys is pumped from principal aquifers in unconsolidated basin-fill deposits. Ground water in these aquifers originates as precipitation in the adjacent mountains and is recharged by the Carson River and by underflow from adjacent upstream valleys. Ground-water flow is generally parallel to the direction of surface-water flow in the Carson River. Ground water is discharged by pumping, evapotranspiration, and underflow into the Carson River.

The results of geochemical modeling indicate that as ground water moves from upland aquifers in mountainous recharge areas to principal aquifers in basin-fill deposits, the following processes probably occur: (1) plagioclase feldspar, sodium chloride, gypsum (or pyrite), potassium feldspar, and biotite dissolve; (2) calcite precipitates; (3) kaolinite forms; (4) small amounts of calcium and magnesium in the water exchange for potassium on aquifer minerals; and (5) carbon dioxide is gained or lost. The geochemical models are consistent with (1) phases identified in basinfill sediments; (2) chemical activity of major cations and silica; (3) saturation indices of calcite and amorphous silica; (4) phase relations for aluminosilicate minerals indicated by activity diagrams; and (5) results of optical, X-ray diffraction, and scanning-electron microscopy examination of mineral grains in the aquifer sediments. Sulfurisotopic composition of ground-water samples also supports the models.

In general, the quality of ground water in the study area meets Nevada State drinking-water standards and is acceptable for most uses. In addition to major ions, samples were analyzed for 22 inorganic trace elements, 3 nutrients, and 4 radionuclides. Selenium in 1 sample is the only constituent that exceeded Nevada State primary drinking-water standards. Nevada State secondary drinking-water standards were exceeded for fluoride in 1 sample, for iron in 7 samples, and for manganese in 19 samples. Minor constituent concentrations are generally the result of local redox conditions, and are primarily from minerals in volcanic and marine metasedimentary rocks, metal-oxide coatings on mineral grains, and organic matter. 
In addition to gross-alpha and gross-beta activities, radionuclide analyses included radon222 , uranium, radium-226, and radium-228. Gross-alpha and gross-beta activities ranged from 0.27 to 21 and 3.0 to 21 picocuries per liter $(\mathrm{pCi} / \mathrm{L})$, with median activities of 1.8 and 7.25 $\mathrm{pCi} / \mathrm{L}$, respectively. Gross-alpha activity is primarily from uranium dissolved in the water. The most likely sources of dissolved uranium are the dissolution of uranium-rich metal-oxide coatings, desorption from the coatings and organic matter, and oxidation of uraniferous organic matter. Gross-beta activity is primarily a result of the decay of potassium- 40 dissolved in the ground water and the ingrowth of uranium-238 progeny in a sample before analysis. The most likely sources of potassium- 40 are the dissolution of potassium feldspar and biotite. Radon-222 ranged from 150 to $1,800 \mathrm{pCi} / \mathrm{L}$, had a median concentration of $580 \mathrm{pCi} / \mathrm{L}$, and was produced by the decay of solid phases of radium-226 in the aquifer. None of the 24 samples with both alpha and uranium analyses exceeded the adjusted gross-alpha maximum contaminant level of $15 \mathrm{pCi} / \mathrm{L}$. The proposed maximum contaminant level of $300 \mathrm{pCi} / \mathrm{L}$ for radon-222 was exceeded in 27 of 35 samples. The proposed maximum contaminant level of $20 \mu \mathrm{g} / \mathrm{L}$ for uranium was exceeded in 3 of 26 samples. None of the 3 radium-226 analyses or the radium-228 analysis exceeded the maximum contaminant level of $5 \mathrm{pCi} / \mathrm{L}$.

Ground-water samples from Dayton, Stagecoach, and Churchill Valleys were analyzed for 61 synthetic organic compounds. Only 3 of these 61 compounds were detected in samples collected during the study period. None of these exceeded Nevada's drinking-water standards.

\section{INTRODUCTION}

\section{Background}

Beginning in 1986, the Congress of the United States has annually appropriated funds for the U.S. Geological Survey to test and refine concepts for a
National Water-Quality Assessment (NAWQA) Program. The long-term goals of a full-scale program are to:

1. Provide a nationally consistent description of current water-quality conditions for a large part of the Nation's surface- and ground-water resources.

2. Define long-term trends (or lack of trends) in water quality.

3. Identify, describe, and explain, as much as possible, the major factors that affect the observed waterquality conditions and trends.

The information will provide water managers, policy makers, and the public with an improved scientific basis for evaluating the effectiveness of waterquality management programs and a data base for assessing the likely effects of proposed changes in land- and water-management practices. Concepts for a full-scale NAWQA Program are described by Hirsch and others (1988).

The NAWQA Program is organized into study units on the basis of specific hydrologic systems. For ground water, the study units are large parts of aquifers or aquifer systems, and for surface water, the study units are major river basins. The study units are large, involving areas ranging from a few thousand to several tens of thousands of square miles.

The assessment program is in a pilot phase in seven project areas throughout the United States. Each area represents diverse geologic and hydrologic environments, and water-quality conditions. The seven pilot projects include four that are concerned with surface water and three that are concerned with ground water. Surface-water pilot studies include the Yakima River Basin in Washington; the lower Kansas River Basin in Kansas and Nebraska; the upper Illinois River Basin in Illinois, Indiana, and Wisconsin; and the Kentucky River Basin in Kentucky. The ground-water project areas are the Carson River Basin in Nevada and California (fig. 1); the Central Oklahoma aquifer in Oklahoma; and the Delmarva Peninsula in Delaware, Maryland, and Virginia. Geochemical and hydrologic data for the Carson River Basin through 1987 are summarized by Welch and others (1989); available data through 1990 used in the preparation of this report are listed in Whitney (1994). 


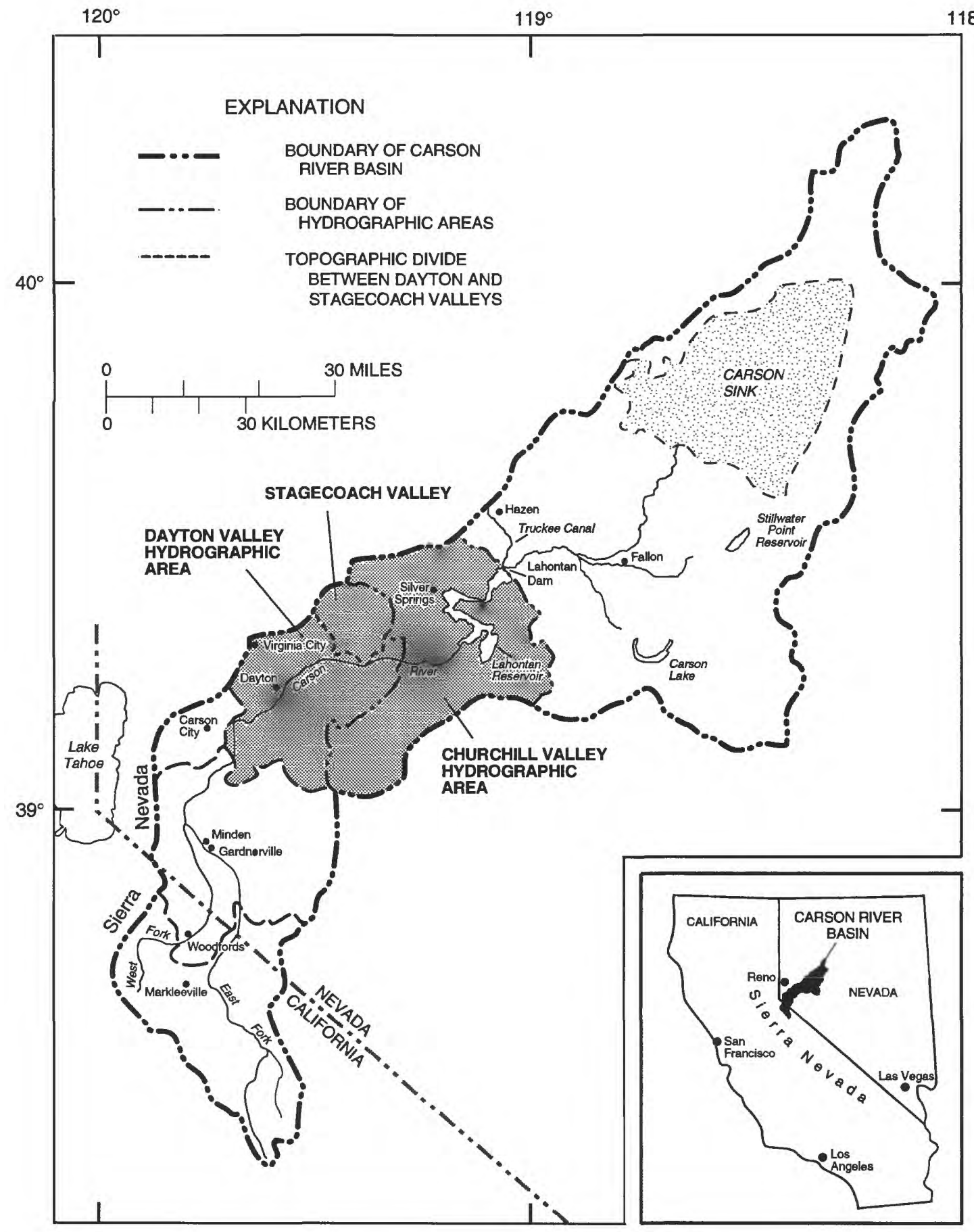

Figure 1. Location of the Dayton Valley and Churchill Valley hydrographic areas within the Carson River Basin pilot NAWQA study area. 
This study is part of the Carson River Basin pilot NAWQA project. The aquifers of primary interest are those used for municipal and domestic water supplies. This report focuses primarily on the ground-water quality and geochemistry in Dayton, Stagecoach, and Churchill Valleys.

Data collected from 1987 to 1990 (Whitney, 1994) as part of the Carson River Basin NAWQA project form much of the basis for this report. Isotope data are evaluated in conjunction with geologic, hydrologic, and geophysical information to describe the ground-water flow systems. The discussion of ground-water quality includes statistically based descriptions of the concentrations of major and minor inorganic constituents, radionuclides, and synthetic organic compounds. For readers desiring more indepth explanations of the processes resulting in the observed water quality, sections for each group of constituents listed above and a description of the mineralogic composition of the sediments have been included in the report.

\section{Location System for Wells}

A local site designation (local well number) is used to identify a site by the official rectangular subdivision of the public lands referenced to the Mount Diablo base line and meridian (table 1). Each site designation consists of three units: The first unit is the township, preceded by an $\mathrm{N}$ or $\mathrm{S}$ to indicate location north or south of the base line. The second unit is the range, preceded by an $E$ to indicate location east of the meridian. The third unit consists of the section number and letters designating the quarter section, quarterquarter section, and so on (A, B, C, and D indicate the northeast, northwest, southwest, and southeast quarters, respectively), followed by a number indicating the sequence in which the site was recorded. For example, well N15 E20 23CDAC1, in Dayton Valley, is the first well recorded in the southwest quarter (C) of the northeast quarter (A) of the southeast quarter (D) of section 23, Township 15 North, Range 20 East, of the Mount Diablo base lines and meridian.
The authors thank the residents and water purveyors in Dayton, Stagecoach, and Churchill Valleys for permitting access to wells for sampling. Larry Benson of the U. S. Geological Survey in Boulder, Colo., provided carbon-13 data for the Carson, Truckee, and Walker Rivers.

\section{DESCRIPTION OF STUDY AREA}

\section{Location and Physiography}

Dayton Valley and Churchill Valley hydrographic areas, designated by the Nevada Division of Water Resources (Rush, 1968), are in the central part of the Carson River Basin of west-central Nevada (fig. 1). The Dayton Valley hydrographic area covers approximately $367 \mathrm{mi}^{2}$ and consists of several subbasins, the largest of which is Carson Plains (fig. 2A). Stagecoach Valley is the other large subbasin; it occupies the northeast part of the Dayton Valley hydrographic area.

Smaller subbasins include the Riverview area, which is a small floodplain along the west bank of the Carson River in the westernmost part of the hydrographic area, and the Mound House area-a small upland basin a few hundred feet above the Carson River. In this report, Dayton Valley refers to all subbasins in the Dayton Valley hydrographic area, excluding Stagecoach Valley.

Dayton Valley is bordered by the Virginia Range to the north, Stagecoach Valley to the northeast, the Pine Nut Mountains to the south and southeast, and Eagle Valley to the west. Stagecoach Valley is bordered by the Virginia Range to the north, Churchill Valley to the east, and Dayton Valley to the south and west (fig. 2A). The Carson River generally flows from west to east across Dayton Valley.

The Churchill Valley hydrographic area covers approximately $486 \mathrm{mi}^{2}$ and is separated from the Dayton Valley hydrographic area by Churchill Butte on the west (fig. 2B). In this report, Churchill Valley refers to all basins and the adjacent mountains in the Churchill Valley hydrographic area. Churchill Valley is bounded to the north by the eastern part of the Virginia Range, to the east by the Dead Camel Mountains, to the south by the Desert Mountains, and to the southwest by the Pine Nut Mountains. The Carson River enters Churchill Valley on its west side just south of Churchill Butte. Lahontan Reservoir impounds Carson River on 
the east side of Churchill Valley. Lahontan Reservoir also receives Truckee River water through the Truckee Canal (fig. 1).

\section{Climate}

Climate of the study area is generally described as subhumid-continental in the high altitudes and midlatitude-steppe at lower altitudes (Houghton and others, 1975 , p. 69 and 71). A subhumid-continental climate is characterized by cold winters, warm summers, and low to moderate precipitation. The midlatitude-steppe climate is characterized by cold winters, hot summers, and semiarid conditions.

Precipitation in the area originates as Pacific storms or Great Basin low-pressure systems (also called "Tonopah lows;" Houghton and others, 1975, p. 13). Precipitation associated with storms that originate as air masses in the northern Pacific generally occur between November and March and snow is the most prevalent form of precipitation. Thunderstorms are common during summer months and are associated with maritime tropical air masses that move into the area from the Gulf of California (Houghton and others, 1975, p. 19). Average annual precipitation ranges from about 10 in. in the western parts of Dayton Valley to about 8 in. in Churchill Valley (Houghton and others, 1975, fig. 40). Mountain ranges typically receive much more precipitation than the adjacent valley floors. Average annual surface-water evaporation ranges from 46 to $48 \mathrm{in}$. within the study area and is 4 to 6 times the average annual precipitation (Houghton and others, 1975, fig. 60).

\section{Land and Water Use}

Range and forest land predominates in Dayton and Stagecoach Valleys (95 percent of total area) and Churchill Valley (86 percent; Welch and others, 1990 , table 3). The population of the study area was less than 5,000 in 1970 and has nearly doubled from about 6,500 in 1980 to 12,500 in 1990 (Maud Naroll, University of Nevada, Reno, Bureau of Business and Economic Research, oral commun., 1992). In Dayton and Stagecoach Valleys, agriculture and barren land each account for 2 percent of land use; wetlands, urbanland, and water bodies account for less than 1 percent of land use. In Churchill Valley, barren land covers 8.8 , water bodies and wetlands cover 4.6 , agriculture covers 0.5 , and urban land covers 0.2 percent of the area. Although these data are for 1973, little change has taken place in land-use practices since 1973, with the exception of increased urbanization. During drought years, the percentage of land covered by water and wetlands is greatly reduced.

Water use in Dayton and Stagecoach Valleys in 1990 was about 24,000 acre-feet (acre-ft) for irrigation and about 2,000 acre-ft for domestic use. Approximately, 17,000 acre-ft of this water was surface water from the Carson River and 9,000 acre-ft was ground water. Water use in Churchill Valley in 1990 was about 8,100 acre-ft for irrigation and about 560 acre-ft for domestic use. Approximately 5,400 acre- $\mathrm{ft}$ of this water was surface water from the Carson River and 3,200 acre-ft was ground water (James Crompton, U.S. Geological Survey, written commun., 1992). The amount of surface water and ground water used for irrigation fluctuates annually depending on flow in the Carson River and the amount of pumping. Historically, water use in the Dayton area provided power for more than 15 stamp mills that processed ore from the Comstock Lode along the Carson River in the late 1800's (Dangberg, 1972, p. 80).

\section{Surface Water}

The primary source of surface water in the study area is the Carson River. The Carson River enters the study area from the southwest and flows generally eastward to Lahontan Reservoir (fig. $2 B$ ). The average annual flow of the Carson River where it enters the study area is estimated to be 272,000 acre-ft (Glancy and Katzer, 1976, table 8). Near the eastern boundary of Churchill Valley, the Truckee Canal is used to import surface water from the Truckee River and convey it to Lahontan Reservoir (fig. 1). The canal enters Churchill Valley near Lahontan Dam, which is near the eastern hydrographic boundary of the valley, and water in the canal discharges into Lahontan Reservoir just upstream from the dam. Average annual flow of the Truckee Canal near Hazen, 3.35 mi upstream from Lahontan Reservoir, is 144,000 acre-ft (Garcia and others, 1992, p. 330). Average annual flow of the Carson River below Lahontan Dam is 378,000 acre-ft, which includes water imported by the Truckee Canal (Glancy and Katzer, 1976, table 8). Kings and Ash Canyon Creeks enter the Carson River from Eagle Valley in the Riverview area. The combined average annual flow for these creeks from 1919 to 1969 was estimated to be 4,000 acre-ft (Glancy and Katzer, 1976, table 12). 
Table 1. Sample site numbers and locations in Dayton, Stagecoach, and Churchill Valleys

[Site sequence is from west to east (decreasing longitude)]

\begin{tabular}{|c|c|c|c|c|}
\hline $\begin{array}{c}\text { Site } \\
\text { number } \\
\text { (fig. 2) }\end{array}$ & $\begin{array}{l}\text { Aquifer } \\
\text { group }\end{array}$ & Latitude & Longitude & Local well number \\
\hline \multicolumn{5}{|c|}{ Dayton and Stagecoach Valleys } \\
\hline 1 & $\mathbf{P}$ & $39^{\circ} 08^{\prime} 40^{\prime \prime}$ & $119^{\circ} 42^{\prime} 10^{\prime \prime}$ & N15 E20 23CDAC1 \\
\hline 2 & $\mathrm{~T}$ & $39^{\circ} 09^{\prime} 14^{\prime \prime}$ & $119^{\circ} 42^{\prime} 00$ & N15 E20 23ABDD2 \\
\hline 3 & $\mathrm{U}$ & $39^{\circ} 17^{\prime} 00^{\prime \prime}$ & $119^{\circ} 40^{\prime} 57^{\prime \prime}$ & N16 E20 01ADAC1 \\
\hline 4 & $\mathrm{U}$ & $39^{\circ} 08^{\prime} 30^{\prime \prime}$ & $119^{\circ} 38^{\prime} 55^{\prime \prime}$ & N15 E21 29BAAC1 \\
\hline 5 & $\mathrm{P}$ & $39^{\circ} 12^{\prime} 59^{\prime \prime}$ & $119^{\circ} 38^{\prime} 42^{\prime \prime}$ & N16 E21 29DCDD1 \\
\hline 6 & $\mathrm{U}$ & $39^{\circ} 15^{\prime} 38^{\prime \prime}$ & $119^{\circ} 38^{\prime} 35^{\prime \prime}$ & N16 E21 08DDCB1 \\
\hline 7 & $\mathbf{P}$ & $39^{\circ} 14^{\prime} 41^{\prime \prime}$ & $119^{\circ} 37^{\prime} 01^{\prime \prime}$ & $\mathrm{N} 16 \mathrm{E} 2115 \mathrm{CCDC} 1$ \\
\hline 8 & $\mathbf{P}$ & $39^{\circ} 13^{\prime} 30^{\prime \prime}$ & $119^{\circ} 35^{\prime} 52^{\prime \prime}$ & N16 E21 26BCB 1 \\
\hline 9 & $\mathbf{P}$ & $39^{\circ} 14^{\prime} 17^{\prime \prime}$ & $119^{\circ} 35^{\prime} 18^{\prime \prime}$ & N16 E21 23ACDD1 \\
\hline 10 & $\mathbf{P}$ & $39^{\circ} 15^{\prime} 19^{\prime \prime}$ & $119^{\circ} 35^{\prime} 17^{\prime \prime}$ & N16 E21 14ADBA1 \\
\hline 11 & $\mathrm{~S}$ & $39^{\circ} 16^{\prime} 10^{\prime \prime}$ & $119^{\circ} 33^{\prime} 59^{\prime \prime}$ & N16 E21 12ADAB1 \\
\hline 12 & $\mathbf{P}$ & $39^{\circ} 16^{\prime} 27^{\prime \prime}$ & $119^{\circ} 33^{\prime} 21^{\prime \prime}$ & N16 E22 06CDDD 1 \\
\hline 13 & $\mathbf{P}$ & $39^{\circ} 18^{\prime} 37^{\prime \prime}$ & $119^{\circ} 33^{\prime} 05^{\prime \prime}$ & N17 E22 30DABCl \\
\hline 14 & $\mathbf{P}$ & $39^{\circ} 19^{\prime} 36^{\prime \prime}$ & $119^{\circ} 31^{\prime} 51^{\prime \prime}$ & N17 E22 20DABB1 \\
\hline 15 & $\mathbf{P}$ & $39^{\circ} 17^{\prime} 23^{\prime \prime}$ & $119^{\circ} 31^{\prime} 50^{\prime \prime}$ & N17 E22 32DDBC1 \\
\hline 16 & $\mathbf{P}$ & $39^{\circ} 16^{\prime} 05^{\prime \prime}$ & $119^{\circ} 31^{\prime} 34^{\prime \prime}$ & N16 E22 09BCBC1 \\
\hline 17 & $\mathbf{P}$ & $39^{\circ} 15^{\prime} 38^{\prime \prime}$ & $119^{\circ} 31^{\prime} 13^{\prime \prime}$ & N16 E22 09CACA1 \\
\hline 18 & $\mathbf{P}$ & $39^{\circ} 18^{\prime} 23^{\prime \prime}$ & $119^{\circ} 29^{\prime} 34^{\prime \prime}$ & N17 E22 27DACC1 \\
\hline 19 & $\mathbf{P}$ & $39^{\circ} 17^{\prime} 40^{\prime \prime}$ & $119^{\circ} 27^{\prime} 24^{\prime \prime}$ & N17 E22 36DABB 1 \\
\hline 21 & U & $39^{\circ} 23^{\prime} 43^{\prime \prime}$ & $119^{\circ} 27^{\prime} 05^{\prime \prime}$ & N18 E22 25DA 1 \\
\hline 22 & $\mathrm{P}$ & $39^{\circ} 19^{\prime} 33^{\prime \prime}$ & $119^{\circ} 26^{\prime} 33^{\prime \prime}$ & N17 E23 19ACBC1 \\
\hline 23 & $\mathbf{P}$ & $39^{\circ} 20^{\prime} 47^{\prime \prime}$ & $119^{\circ} 26^{\prime} 05^{\prime \prime}$ & N17 E23 07DDDD1 \\
\hline 24 & $\mathbf{P}$ & $39^{\circ} 20^{\prime} 17^{\prime \prime}$ & $119^{\circ} 26^{\prime} 05^{\prime \prime}$ & N17 E23 17 \\
\hline 25 & $\mathbf{P}$ & $39^{\circ} 20^{\prime} 07^{\prime \prime}$ & $119^{\circ} 25^{\prime} 35^{\prime \prime}$ & N17 E23 17DCBC1 \\
\hline 26 & $\mathrm{U}$ & $39^{\circ} 23^{\prime} 34^{\prime \prime}$ & $119^{\circ} 25^{\prime} 20^{\prime \prime}$ & N18 E23 29DD 1 \\
\hline 27 & $\mathrm{U}$ & $39^{\circ} 22^{\prime} 38^{\prime \prime}$ & $119^{\circ} 25^{\prime} 18^{\prime \prime}$ & N18 E23 32DD \\
\hline 28 & $\mathrm{U}$ & $39^{\circ} 22^{\prime} 42^{\prime \prime}$ & $119^{\circ} 25^{\prime} 03^{\prime \prime}$ & N18 E23 32DDA 1 \\
\hline 29 & $\mathbf{P}$ & $39^{\circ} 22^{\prime} 37^{\prime \prime}$ & $119^{\circ} 24^{\prime} 52^{\prime \prime}$ & N18 E23 33CCB 1 \\
\hline 30 & $\mathbf{P}$ & $39^{\circ} 22^{\prime} 01^{\prime \prime}$ & $119^{\circ} 24^{\prime} 50^{\prime \prime}$ & N17 E23 04CBBB2 \\
\hline 31 & $\mathrm{P}$ & $39^{\circ} 20^{\prime} 50^{\prime \prime}$ & $119^{\circ} 24^{\prime} 47^{\prime \prime}$ & N17 E23 09CCDC1 \\
\hline 32 & $\mathbf{P}$ & $39^{\circ} 21^{\prime} 41^{\prime \prime}$ & $119^{\circ} 24^{\prime} 06^{\prime \prime}$ & N17 E23 04DDCC1 \\
\hline 33 & $\mathrm{P}$ & $39^{\circ} 21^{\prime} 10^{\prime \prime}$ & $119^{\circ} 23^{\prime} 50^{\prime \prime}$ & N17 E23 09DAAA1 \\
\hline 34 & $\mathrm{P}$ & $39^{\circ} 21^{\prime} 18^{\prime \prime}$ & $119^{\circ} 23^{\prime} 49^{\prime \prime}$ & N17 E23 10BCCA1 \\
\hline 35 & $\mathbf{P}$ & $39^{\circ} 20^{\prime} 08^{\prime \prime}$ & $119^{\circ} 23^{\prime} 33^{\prime \prime}$ & N17 E23 15CCAA1 \\
\hline 36 & $\mathrm{P}$ & $39^{\circ} 21^{\prime} 32^{\prime \prime}$ & $119^{\circ} 23^{\prime} 25^{\prime \prime}$ & N17 E23 10BABD1 \\
\hline 37 & $\mathbf{P}$ & $39^{\circ} 21^{\prime} 26^{\prime \prime}$ & $119^{\circ} 23^{\prime} 09^{\prime \prime}$ & N17 E23 10ABCD1 \\
\hline 38 & $\mathbf{P}$ & $39^{\circ} 18^{\prime} 57^{\prime \prime}$ & $119^{\circ} 23^{\prime} 07^{\prime \prime}$ & N17 E23 $27 \mathrm{ABAC} 1$ \\
\hline 39 & $\mathbf{P}$ & $39^{\circ} 17^{\prime} 19^{\prime \prime}$ & $119^{\circ} 23^{\prime} 04^{\prime \prime}$ & N16 E23 03ABAA1 \\
\hline 40 & P & $39^{\circ} 18^{\prime} 12^{\prime \prime}$ & $119^{\circ} 22^{\prime} 40^{\prime \prime}$ & N17 E23 26CCCC1 \\
\hline 41 & $\mathbf{P}$ & $39^{\circ} 21^{\prime} 44^{\prime \prime}$ & $119^{\circ} 22^{\prime} 34^{\prime \prime}$ & $\mathrm{N} 17 \mathrm{E} 23$ 02BC 1 \\
\hline
\end{tabular}


Table 1. Sample site numbers and locations in Dayton,

Stagecoach, and Churchill Valleys-Continued

\begin{tabular}{|c|c|c|c|c|}
\hline $\begin{array}{c}\text { Site } \\
\text { number } \\
\text { (fig. 2) }\end{array}$ & $\begin{array}{l}\text { Aquifer } \\
\text { group }^{2}\end{array}$ & Latitude & Longitude & Local well number \\
\hline \multicolumn{5}{|c|}{ Dayton and Stagecoach Valleys-Continued } \\
\hline 42 & $\mathbf{P}$ & $39^{\circ} 22^{\prime} 46^{\prime \prime}$ & $119^{\circ} 22^{\prime} 29^{\prime \prime}$ & N18 E23 35CBDD1 \\
\hline 43 & $\mathrm{P}$ & $39^{\circ} 21^{\prime} 45^{\prime \prime}$ & $119^{\circ} 22^{\prime} 29^{\prime \prime}$ & N17 E23 02CCDA2 \\
\hline 44 & $\mathbf{P}$ & $39^{\circ} 22^{\prime} 35^{\prime \prime}$ & $119^{\circ} 21^{\prime} 56^{\prime \prime}$ & N18 E23 35DCDC1 \\
\hline 45 & $\mathbf{P}$ & $39^{\circ} 21^{\prime} 32^{\prime \prime}$ & $119^{\circ} 21^{\prime} 51^{\prime \prime}$ & N17 E23 11AA 1 \\
\hline 46 & $\mathbf{P}$ & $39^{\circ} 21^{\prime} 46^{\prime \prime}$ & $119^{\circ} 21^{\prime} 42^{\prime \prime}$ & N17 E23 01CC 1 \\
\hline 47 & $\mathbf{P}$ & $39^{\circ} 17^{\prime} 58^{\prime \prime}$ & $119^{\circ} 21^{\prime} 10^{\prime \prime}$ & N17 E23 36BADC1 \\
\hline 48 & $\mathrm{P}$ & $39^{\circ} 21^{\prime} 53^{\prime \prime}$ & $119^{\circ} 20^{\prime} 42^{\prime \prime}$ & N17 E23 01DDB 1 \\
\hline \multicolumn{5}{|c|}{ Churchill Valley } \\
\hline 49 & $\mathbf{P}$ & $39^{\circ} 23^{\prime} 30^{\prime \prime}$ & $119^{\circ} 17^{\prime} 54^{\prime \prime}$ & N18 E24 28CDBD1 \\
\hline 50 & $\mathbf{P}$ & $39^{\circ} 23^{\prime} 11^{\prime \prime}$ & $119^{\circ} 17^{\prime} 45^{\prime \prime}$ & N18 E24 33BDAA1 \\
\hline 51 & $\mathbf{P}$ & $39^{\circ} 25^{\prime} 18^{\prime \prime}$ & $119^{\circ} 17^{\prime} 04^{\prime \prime}$ & N18 E24 15CCBA1 \\
\hline 52 & $\mathbf{P}$ & $39^{\circ} 22^{\prime} 26^{\prime \prime}$ & $119^{\circ} 16^{\prime} 21^{\prime \prime}$ & N17 E24 03ABAD1 \\
\hline 53 & $\mathrm{P}$ & $39^{\circ} 17^{\prime} 28^{\prime \prime}$ & $119^{\circ} 16^{\prime} 06^{\prime \prime}$ & N17 E24 34DDAC1 \\
\hline 54 & $\mathrm{P}$ & $39^{\circ} 23^{\prime} 20^{\prime \prime}$ & $119^{\circ} 15^{\prime} 09^{\prime \prime}$ & N18 E24 35ABAD 1 \\
\hline 55 & $\mathbf{P}$ & $39^{\circ} 24^{\prime} 03^{\prime \prime}$ & $119^{\circ} 13^{\prime} 51^{\prime \prime}$ & N18 E24 25AADC1 \\
\hline 56 & $\mathrm{P}$ & $39^{\circ} 19^{\prime} 52^{\prime \prime}$ & $119^{\circ} 12^{\prime} 40^{\prime \prime}$ & N17 E25 18DDD 1 \\
\hline 57 & $\mathbf{P}$ & $39^{\circ} 25^{\prime} 15^{\prime \prime}$ & $119^{\circ} 12^{\prime} 37^{\prime \prime}$ & N18 E25 17CCBC1 \\
\hline 58 & $S$ & $39^{\circ} 18^{\prime} 08^{\prime \prime}$ & $119^{\circ} 12^{\prime} 07^{\prime \prime}$ & N17 E25 32BAAA1 \\
\hline 59 & $\mathbf{P}$ & $39^{\circ} 23^{\prime} 49^{\prime \prime}$ & $119^{\circ} 11^{\prime} 43^{\prime \prime}$ & N18 E25 29ADCD1 \\
\hline 60 & $\mathrm{~S}$ & $39^{\circ} 18^{\prime} 47^{\prime \prime}$ & $119^{\circ} 11^{\prime} 38^{\prime \prime}$ & N17 E25 29ADAB1 \\
\hline
\end{tabular}

${ }^{a}$ Aquifer groups: U, upland; S, shallow; P, principal; and T, thermal. See figure 2.

All other surface water in the study area is ephemeral; streams flow only during severe storms and when snow melts in the uplands.

The Carson River has uncontrolled flows above Lahontan Reservoir. During the summer, the river is diverted for irrigation in the study area and upstream in Carson Valley, reducing the natural flow of the river in the study area. Some of the water used for irrigation recharges shallow aquifers; however, the interaction between ground water and surface water is not well understood. Depending on the stage of the river, the river can be a source of recharge water or receive discharge from the basin-fill aquifer (Welch and others, 1989, p. 14-15). For example, approximately 1,500 acre-ft/yr of ground water discharges to the Carson River in the Riverview area during low and normal flows (Arteaga and Durbin, 1978, p. 32). The Carson River probably recharges parts of the shallow basin-fill aquifer adjacent to the river channel during periods of high flow, particularly when the river is at flood stage, and from irrigation during the growing season. Evidence that the basin-fill aquifer in southern Stagecoach Valley is recharged by water from the Carson River is provided by Harrill and others (1984) and is summarized in the section of this report titled "Occurrence and Movement of Ground Water and Isotope Hydrology." In an effort to further define the conclusions of Harrill and others (1984), statistical analysis of principal components using waterchemistry data was undertaken. The results were inconclusive.

\section{Ground Water}

\section{Hydrogeologic Setting}

Basin-fill deposits in the valleys contain aquifers that are the major source of ground water in the study area. Basin-fill deposits consist of unconsolidated and 


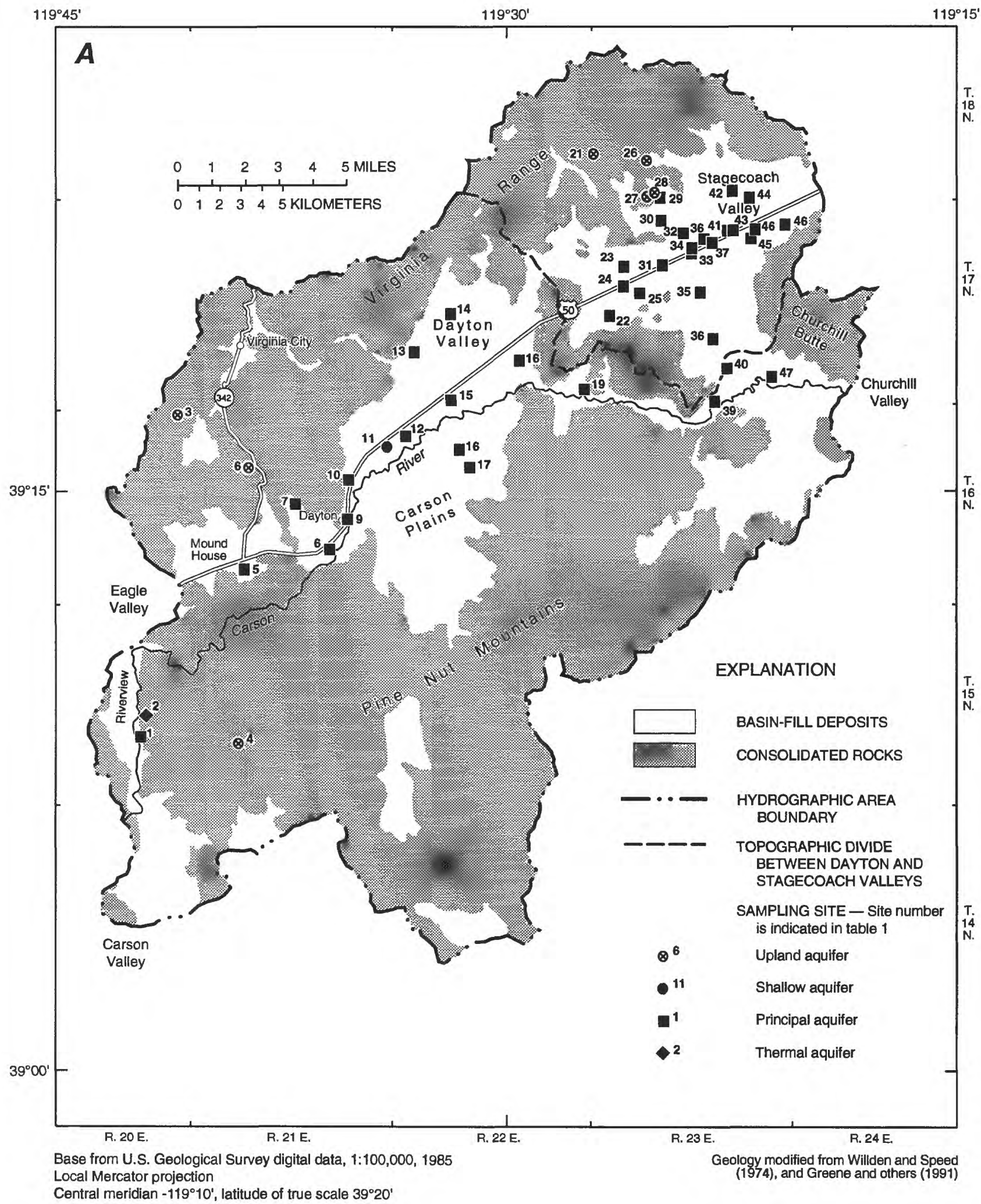

Figure 2. General features and sampling sites in $A$, Dayton and Stagecoach Valleys, and $B$, Churchill Valley. 


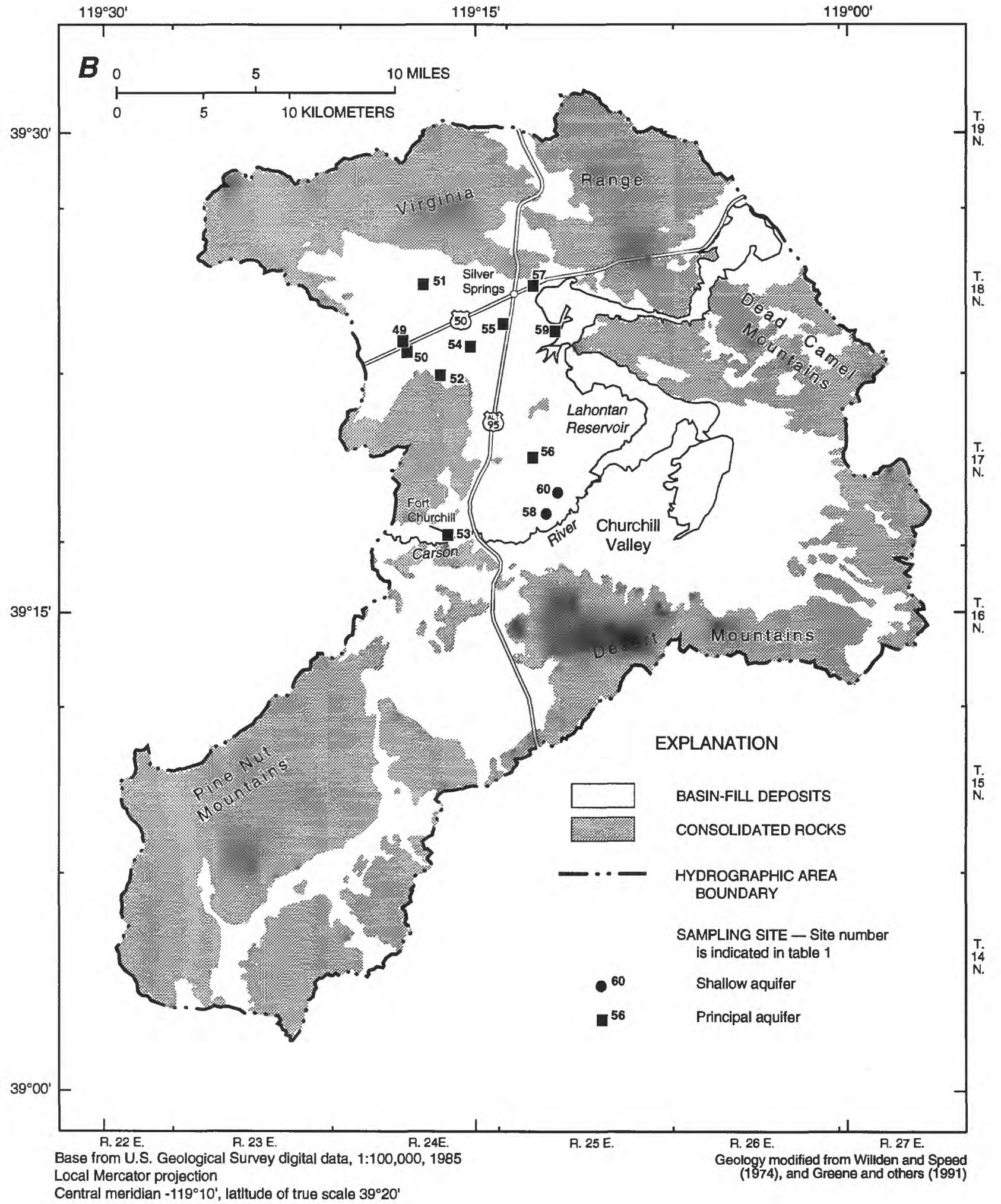

Figure 2.-Continued 
semiconsolidated alluvial, fluvial, and lacustrine materials that occupy structural depressions created by Late Tertiary and Quaternary extensional faulting. These deposits have a maximum thickness of about $2,900 \mathrm{ft}$ in the northwestern part of Dayton Valley and thin towards the southeast, are about 3,000 ft thick in Stagecoach Valley in an area that extends from the north-central to the south-central part of the valley, and are about 2,900 ft thick in the northern part of Churchill Valley and about 2,100 ft thick in the southern part of the valley. The basin-fill deposits are bounded laterally by consolidated rocks in mountains and at depth by down-faulted consolidated rocks, consisting primarily of Triassic to Jurassic granitic rocks and Tertiary sedimentary rocks (Schaefer and Whitney, 1992).

On the basis of differences in lithology, the rocks and sediments in the study area were grouped into five hydrogeologic units by Schaefer and Whitney (1992). These units are the same as those referred to by Welch and others (1989), except that the Tertiary sedimentary rocks are grouped with the Quaternary basin-fill deposits. The hydrogeologic units are (1) Quaternary and Tertiary basin-fill deposits that consist of tuffaceous sandstone, siltstone, rhyolitic tuff, and clays, silts, sands, and gravels; (2) Quaternary and Tertiary basic volcanic rocks that consist of basalt, andesite, and trachyte; (3) Quaternary and Tertiary silicic volcanic rocks that consist of rhyolite, latite, and dacite; (4) Jurassic and Triassic granitic rocks-primarily granodiorite and quartz monzonite; and (5) Jurassic and Triassic metasedimentary and metavolcanic rocks (fig. 3).

Basin-fill deposits include sediments associated with alluvial fans, pediments, valley lowlands, Pleistocene Lake Lahontan, ancient Carson River deltas, and river flood plains (fig. 3). They consist of Quaternary to Tertiary unconsolidated, sorted to unsorted, clay, silt, sand, and gravel (Schaefer and Whitney, 1992). Pleistocene Lake Lahontan covered much of the lowland areas in Stagecoach and Churchill Valleys during its high stand (Benson and Thompson, 1987, p. 84). Thus, valley lowlands are at least partly underlain by fine-grained lacustrine sediments (Moore, 1969).

Metamorphic and granitic hydrogeologic units generally have low permeability. Basic and silicic volcanic hydrogeologic units generally have low permeability, but can have high permeability where highly fractured. Basin-fill deposits are very permeable except for sediments that contain a large percentage of clay, which causes low permeability (Schaefer and Whitney, 1992, table 1).

\section{Mineralogic Composition of the Basin-Fill Sediments}

The mineralogic composition of basin-fill sediments is the result of physical and chemical weathering of consolidated rocks in the surrounding mountains, the transport of sediments into the area by the Carson River, and the physical and chemical weathering of sediments that were deposited in ancient lakes. Dayton and Stagecoach Valleys are bounded mainly by mountain ranges composed of basic volcanic rocks (fig. $3 A$ ). Metasedimentary rocks in the western part of Dayton Valley contain interbedded gypsum deposits (Bingler, 1977). Consolidated rocks underlying the basin-fill sediments are probably of volcanic and granitic origin (Schaefer and Whitney, 1992). Churchill Valley is surrounded primarily by basic volcanic rocks (fig. $3 B$ ) and the basin-fill deposits are probably underlain by sedimentary, volcanic, and granitic rocks (Schaefer and Whitney, 1992). Minerals identified in the basin-fill sediments were considered to be solid phases in geochemical models that were used to determine processes that produced the observed ground-water chemistry. Mineralogic composition of the basin-fill sediments was determined by petrographic examination, $\mathrm{x}$-ray diffractometry, and scanning-electron microscopy for five samples (Patrick Goldstrand, U.S. Geological Survey, written commun., 1990). These samples were collected as cores and cuttings during the hollow-stem auger drilling of shallow wells (less than $50 \mathrm{ft}$ deep). Chemical analyses for splits of these samples were reported by Tidball and others (1991). Mineralogical description of the sediment samples is summarized in table 2.

Mineralogic composition of basin-fill sediments indicates they were locally derived from mafic volcanic, metamorphic, and granitic source rocks. Basin-fill sediments consist primarily of volcanic lithic fragments, sedimentary lithic fragments, plagioclase grains, and quartz grains (table 2). In addition, $\mathrm{K}$-feldspar, biotite, and opaque minerals (magnetite and ilmenite), pyroxene (mostly augite) were identified in the sediments. The volcanic lithic fragments are mostly basaltic lithic grains (primarily plagioclase). The groundmass (material between the mineral crystals) has undergone chlorite alteration. 
Plagioclase is generally unaltered, but a small percentage of the grains have abundant sericite alteration.

Augite is the major mafic mineral within the volcanic lithic fragments and is slightly altered to chlorite.

Pyroxene phenocrysts commonly have hematite rims

(Patrick Goldstrand, U.S. Geological Survey, written commun., 1990).

Sedimentary lithic fragments are composed mainly of silt-size grains of quartz and feldspar; volcanic lithic fragments are also present (table 2). The feldspar and volcanic lithic fragments show alteration to chlorite, sericite, and hematite. Biotite and pyroxene were also identified in trace amounts in these fragments. The matrix is primarily clay with some calcium carbonate in the Churchill Valley sediments. The clay minerals are primarily montmorillonite and illite, with lesser amounts of kaolinite and chlorite. Quartz, plagioclase, and $\mathrm{K}$-feldspar also are present in the clay-size fraction. Calcium carbonate is present as rims on grains, indicating precipitation of calcium carbonate from the ground water (Patrick Goldstrand, U.S. Geological Survey, written commun., 1990).

Plagioclase grains are primarily oligoclase and andesine (table 2). Voids within the grains are commonly filled with chlorite and sericite. Chlorite is the most common alteration product, occurring on cleavages and grain boundaries. Sericite is less common, but is abundant on some grains. Quartz grains show no alteration. Thin chloritic rims on mineral grains are most likely a result of weathering. Potassium feldspar grains are not abundant, and have only slight chlorite alteration. Biotite and augite grains show moderate to strong chlorite alteration. They have rough, jagged grain boundaries, indicating slight dissolution of the grains. Opaque minerals, magnetite and ilmenite, commonly have thin rims of hematite (Patrick Goldstrand, U.S. Geological Survey, written commun., 1990).

\section{Occurrence and Movement of Ground Water and Isotope Hydrology}

For purposes of interpretation, aquifers in the study area were separated into four groups and informally named. Aquifers at altitudes of $4,900 \mathrm{ft}$ and greater are referred to as "upland aquifers." Aquifers at altitudes of less than 4,900 ft and less than $50 \mathrm{ft}$ below the land surface are termed "shallow aquifers." Aquifers at altitudes of less than $4,900 \mathrm{ft}$ and greater than $50 \mathrm{ft}$ below land surface are the "principal aqui- fers." Aquifers containing water with temperatures greater than $30^{\circ} \mathrm{C}$ are called "thermal aquifers." Thermal water is representative of water that has circulated to depths of several thousand feet. Water from principal aquifers is the primary source of ground water used for irrigation, municipal, and domestic supplies.

Ground-water flow is generally parallel to the Carson River in the study area, although it probably flows toward the river from basin-fill deposits adjacent to the river channel. Ground water in the study area moves approximately parallel to the Carson River from west to east, in the same direction the Carson River flows, on the basis of water-level measurements in wells made in the early 1980's (Schaefer and Whitney, 1992). Near the river, ground water probably flows toward the river in basin-fill deposits adjacent to the river channel. Water in unconsolidated deposits in the basins is mainly unconfined, although in localized areas of clay or other fine-grained materials, the ground water may be under confined conditions (Schaefer and Whitney, 1992). Water in upland aquifers is locally derived from precipitation. Water in shallow and principal aquifers is derived by subsurface inflow from upland aquifers in the adjacent mountains, infiltration of runoff from surrounding mountains, leakage from the Carson River, and subsurface underflow from adjacent valleys. Recharge from mountains was estimated to be 7,900 acre-ft/yr in Dayton and Stagecoach Valleys and 1,300 acre-ft/yr in Churchill Valley (Glancy and Katzer, 1976, table 17). Recharge from the Carson River has not been quantified, but the difference between the average annual streamflow into and out of Dayton Valley is 8,000 acre-ft (Glancy and Katzer, 1976, table 12). However, this net loss includes surface water used for irrigation and evapotranspiration along the river. The actual amount of recharge from the Carson River, therefore, is less than 8,000 acre- $\mathrm{ft}$. A satisfactory estimate of net loss from the Carson River in Churchill Valley cannot be determined because of the large and variable amount of evaporation from Lahontan Reservoir and the variable amount of Truckee River water that flows through the Truckee Canal into Lahontan Reservoir. Other conditions that make estimates difficult are the changing surface area of Lahontan Reservoir and the surrounding wetlands in response to water removed for irrigation and drought. Ground-water inflow to Dayton Valley from Carson and Eagle Valleys was estimated to be about 1,600 acre-ft/yr and inflow to Churchill Valley 


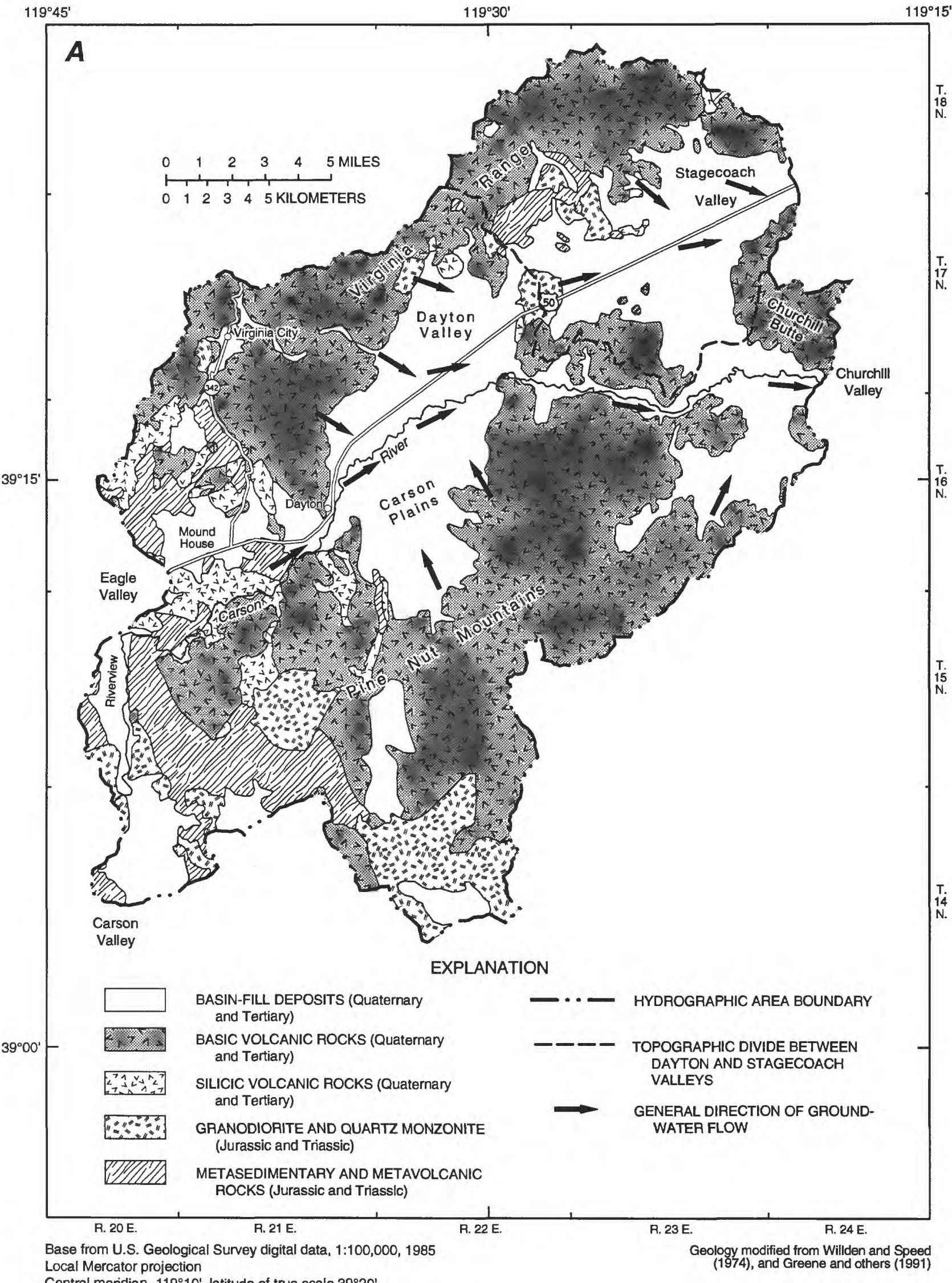

Central meridian $-119^{\circ} 10^{\prime}$, latitude of true scale $39^{\circ} 20^{\prime}$

Figure 3. Hydrogeologic units in $A$, Dayton and Stagecoach Valleys, and $B$, Churchill Valley 


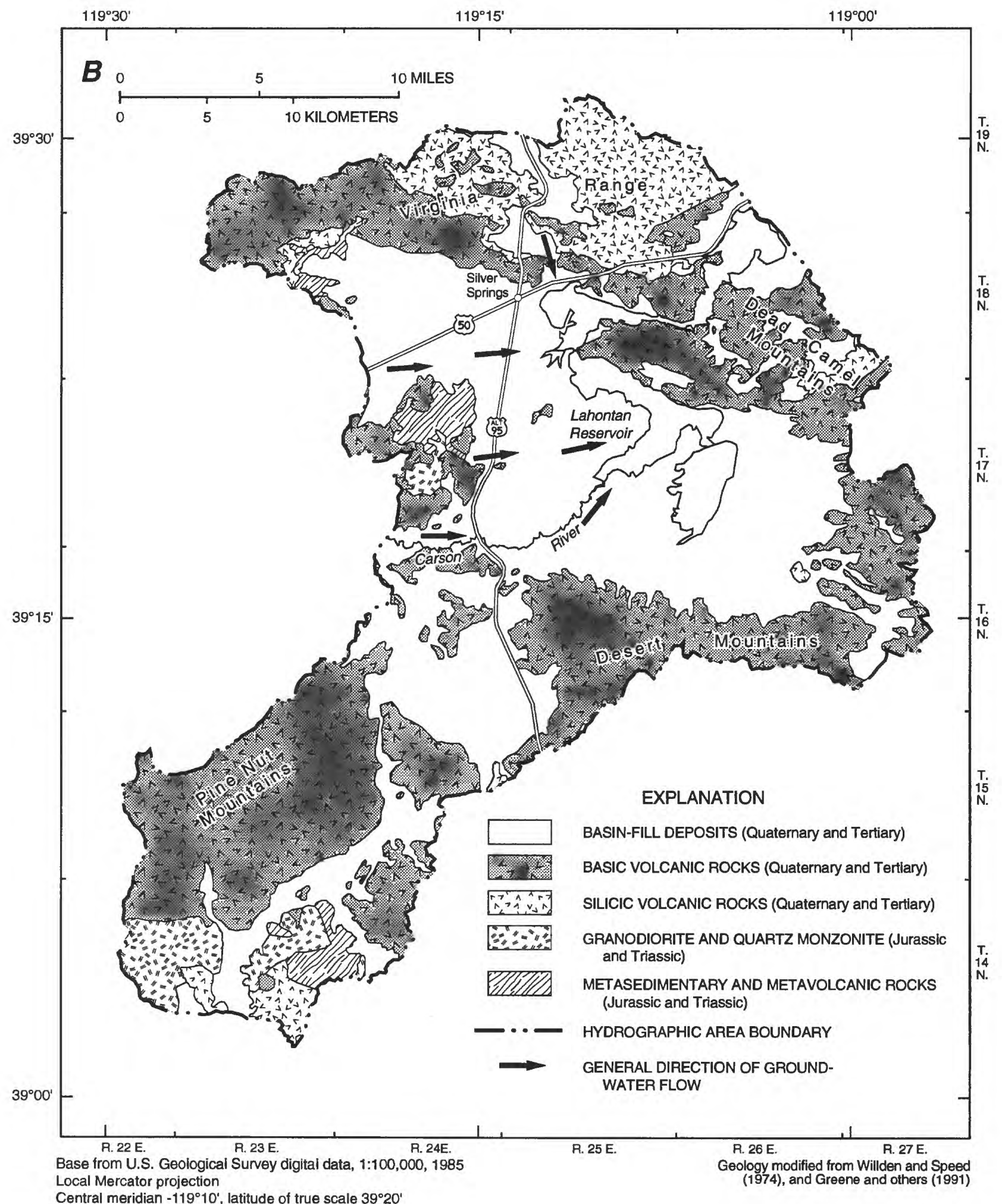

Figure 3.-Continued 
Table 2. Identification, abundance, and alteration of minerals in composite of five shallow sediment samples

[Data from Patrick Goldstrand (U.S. Geological Survey, written commun., 1990). The five samples are from sites 11, 16, 58, and 60 in figure 2 and a site approximately 1 mile west of site 2 and on west side of Carson River]

\begin{tabular}{lcc}
\hline Minerals & $\begin{array}{c}\text { Abundance } \\
\text { (percent) }\end{array}$ & Alteration \\
\hline
\end{tabular}

Volcanic lithic fragments

$$
\begin{aligned}
& \text { Basalt fragments } \\
& \text { plagioclase } \\
& \text { groundmass } \\
& \text { augite } \\
& \text { opaque minerals }
\end{aligned}
$$

Siliceous tuff fragments

glass

quartz

feldspar

hornblende

biotite

Meta-andesite fragments

groundmass

plagioclase

hornblende

\section{Sedimentary lithic fragments}

matrix
quartz
feldspar
volcanic lithic fragments

Plagioclase

$$
\begin{aligned}
& \text { albite } \\
& \text { oligoclase } \\
& \text { andesine }
\end{aligned}
$$

labradorite

Quartz

\section{K-feldspar}

Biotite

Opaque minerals

Pyroxene (mostly augite)

\section{9}

90

65 About 10 percent has abundant sericite; remainder is unaltered

30 Chlorite (60 percent) and hematite ( 40 percent)

3 Sparse chlorite and some hematite rims

2 Magnetite and ilmenite with thin oxidized rims

100

5

75 Devitrified; sparse chlorite

10 None

10 None

3 Sparse chlorite

2 Sparse chlorite

100

5

60 Abundant chlorite

35 Abundant sericite and illite

5 Abundant chlorite

$100 \quad 100$

27

35 Montmorillonite, illite, kaolinite, and chlorite (in order of abundance)

30 None

20 Chlorite and sericite

15 Chlorite, hematite rims, and sericite

100

19

Sparse chlorite along cleavages and as coatings; sericite is less common, but abundant on about 10 percent of the grains

$\begin{array}{r}4 \\ 35 \\ 47 \\ 14 \\ \hline 100\end{array}$

18

None

Sparse chlorite and sericite

Abundant chlorite with slight dissolution along edges

Magnetite or ilmenite with thin, oxidized hematite rims

Abundant chlorite with slight dissolution (mostly augite) 


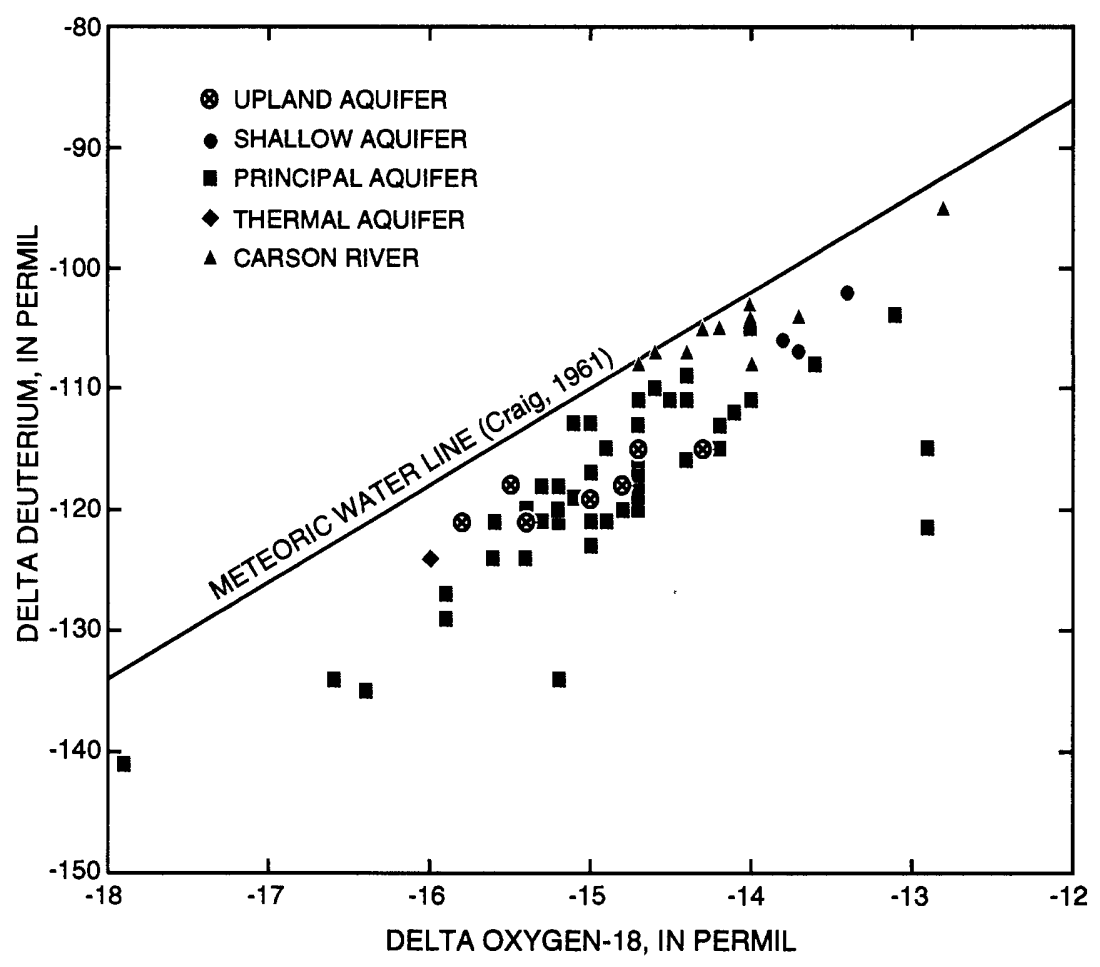

Figure 4. Relation of deuterium and oxygen-18 in water samples from Dayton, Stagecoach, and Churchill Valleys.

from Dayton and Mason Valleys was estimated to be about 200 acre-ft/yr (fig. 2; and Glancy and Katzer, 1976, table 18).

Water in the basin-fill aquifers is discharged by pumping for domestic, irrigation, and industrial uses; by evapotranspiration; by flow into the Carson River; and possibly by subsurface flow to other basins. Ground-water use for 1990 was about 9,000 acre-ft for Dayton and Stagecoach Valleys and about 3,200 acre$\mathrm{ft}$ for Churchill Valley (James Crompton, U.S. Geological Survey, written commun., 1992). The amount of ground water lost by evapotranspiration and subsurface flow into the Carson River and adjacent basins is unknown (Glancy and Katzer, 1976).

Water molecules contain deuterium $\left({ }^{2} \mathrm{H}\right)$ and oxygen-18 $\left({ }^{18} \mathrm{O}\right)$ in varying concentrations. Deuterium concentration is expressed relative to hydrogen-1 $\left({ }^{2} \mathrm{H} /{ }^{1} \mathrm{H}\right)$ and reported as delta deuterium $(\delta \mathrm{D})$; oxygen18 concentration is expressed relative to oxygen- 16 $\left({ }^{18} \mathrm{O} /{ }^{16} \mathrm{O}\right)$ and reported as delta oxygen-18 $\left(\delta^{18} \mathrm{O}\right)$. Both isotopes are reported relative to Vienna Standard Mean Ocean Water (VSMOW) in parts per thousand (permil; Fritz and Fontes, 1980). The $\delta \mathrm{D}$ and $\delta^{18} \mathrm{O}$ concentrations of ground water that originate as precipitation in different recharge areas generally are differ- ent, so they can be used to help determine sources of ground water. In general, $\delta \mathrm{D}$ and $\delta^{18} \mathrm{O}$ concentrations of nonthermal ground water are affected only by evaporation. Evaporation produces a water that is heavier (less negative) in both $\delta \mathrm{D}$ and $\delta^{18} \mathrm{O}$ relative to the original water, which causes the water to graphically plot to the right of water unaffected by evaporation on a $\delta \mathrm{D}-$ $\delta^{18} \mathrm{O}$ plot.

Ground water in the study area may be derived from several sources that have different $\delta D$ concentrations. Ground-water samples from upland aquifers, adjacent to Dayton and Stagecoach Valleys, range in $\delta \mathrm{D}$ content from -121 to -115 permil (figs. 4 and $5 A$ ). The Carson River is isotopically the heaviest (least negative) source of recharge in the study area (fig. 4), with $\delta \mathrm{D}$ ranging from -108 to -103 permil (with the exception of 1 of the 11 samples, which was -95 permil; Harrill and others, 1992, table 1).

Deuterium content of ground-water samples from the principal aquifers of Dayton and Stagecoach Valleys generally is similar to ground water in upland aquifers of the adjacent Virginia Range and Pine Nut Mountains (fig. 5A). Some ground-water samples near the Carson River are heavier than ground water in the adjacent principal and upland aquifers. These samples 


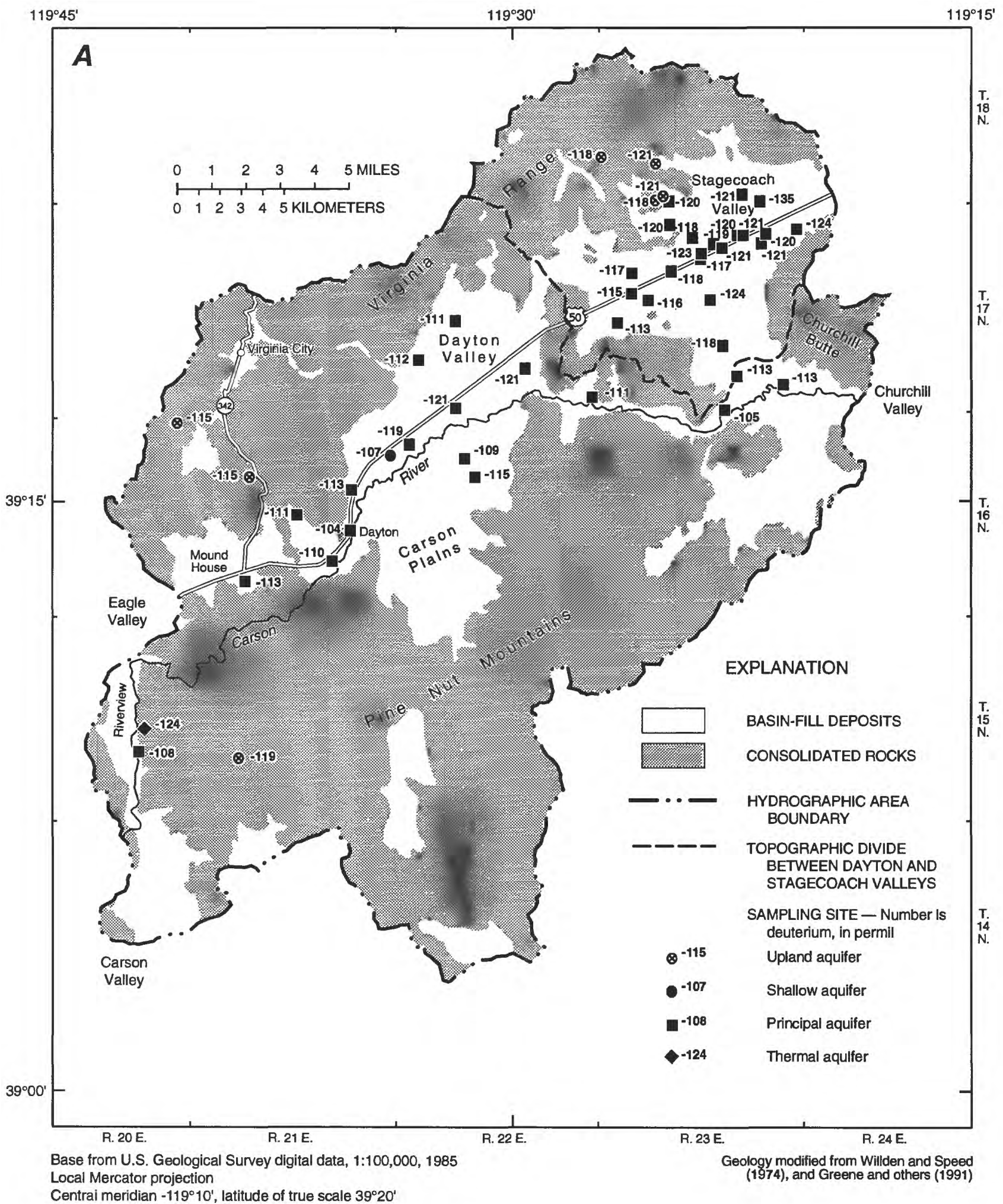

Figure 5. Deuterium composition of ground-water samples from A, Dayton and Stagecoach Valleys, and $B$, Churchill Valley. 


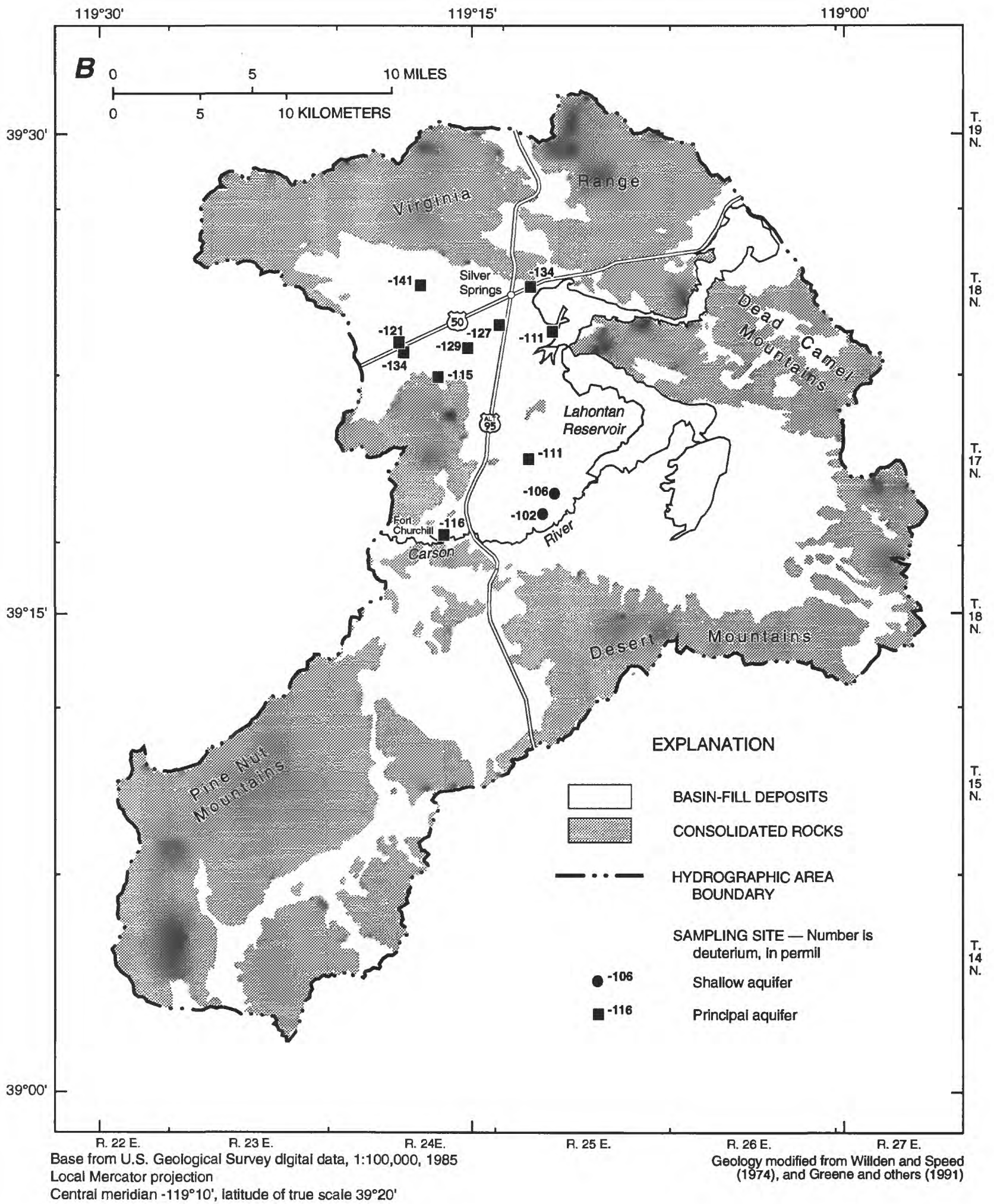

Figure 5.-Continued 
probably contain water infiltrated from the Carson River, because their $\delta \mathrm{D}$ content is similar to that of river water or is between that of river water and water in adjacent principal aquifers. An influx of river water into the principal aquifers was previously proposed by Harrill and others (1992).

Water in the principal and shallow aquifers of Churchill Valley can be grouped on the basis of location and $\delta \mathrm{D}$ content (fig. $5 B$ ). Ground water in the northwestern part of the basin is several miles away, and upgradient from the Carson River and Lahontan Reservoir and the samples have a $\delta \mathrm{D}$ composition ranging from -141 to -121 permil, with the exception of one sample (-115 permil), which has been evaporated (fig. 4), and one sample (-111 permil) which contains Lahontan Reservoir water (fig. 5B). The source of the isotopically light water (-141 to -121 permil) is unknown. This water may have been recharged during the last glacial period, although ages calculated for four of these waters (later in this report) indicate that the water in this aquifer is younger than the last glacial period. If these waters were recharged during this period of probable cooler climate they would be isotopically lighter than present recharge water. Groundwater samples from the southern and eastern parts of the basin along the Carson River and adjacent to Lahontan Reservoir have a $\delta \mathrm{D}$ content ranging from -116 to -102 permil, which is an indication of the influx of river water into the aquifers.

Tritium can be used as an indicator of water that has recently been exposed to the atmosphere. Tritium is a radioactive isotope of hydrogen $\left({ }^{3} \mathrm{H}\right)$ that is part of the water molecule and has a half life of 12.33 years (Friedlander and others, 1981). Tritium is produced in the upper atmosphere by the impact of cosmic neutrons on nitrogen nuclei, resulting in a near steady-state concentration of about 25 picocuries per liter $(\mathrm{pCi} / \mathrm{L})$ in precipitation (Fritz and Fontes, 1980, p. 79). Aboveground testing of hydrogen bombs, beginning in 1952 in the northern hemisphere, resulted in large releases of tritium to the atmosphere, so that ground water that originated from precipitation during the period of above-ground testing may contain $100 \mathrm{pCi} / \mathrm{L}$ of tritium or more. A ban on atmospheric testing in 1963 resulted in declining atmospheric tritium concentration that is now approaching the pre-1952 level of $25 \mathrm{pCi} / \mathrm{L}$. Ground water containing less than $1 \mathrm{pCi} / \mathrm{L}$ of tritium was recharged more than 57 years ago, assuming an initial atmospheric concentration of $25 \mathrm{pCi} / \mathrm{L}$. The most likely sources of water younger than 57 years are the Carson River, and associated irrigation water, and water in upland aquifers.

Of the samples analyzed for tritium, 7 of 22 contained concentrations greater than $1 \mathrm{pCi} / \mathrm{L}$ (fig. 6). Most of these samples are from wells near the Carson River, which indicates that water from the river, or from surface-water irrigation, probably has infiltrated the aquifers. This conclusion generally is supported by $\delta \mathrm{D}$ values for these samples, which range from -119 to -104 permil, indicating that the samples are primarily river water, or a mixture of river and principal-aquifer water. The other two samples with more than $1 \mathrm{pCi} / \mathrm{L}$ of tritium are from a mountainous recharge area (site 6; fig. $2 A$ ) and an alluvial fan adjacent to recharge areas (site 17).

The low levels of tritium in principal aquifers that are not adjacent to the Carson River indicates that water in the principal aquifers was recharged more than 57 years ago. This is expected because (1) there is no irrigation in areas away from the river, except for limited irrigation by well water in Stagecoach Valley (Welch and others, 1989), and (2) flow paths are several miles long from mountainous recharge areas and the Carson River to wells completed in the principal aquifers. The low levels of tritium in principal aquifers in Stagecoach Valley also indicate that ground water used for irrigation in this valley within the past 57 years has not infiltrated the principal aquifers.

\section{WATER QUALITY AND AQUEOUS GEOCHEMISTRY}

\section{Sampling and Analytical Methods}

Surface-water samples were collected at a gaging station on the Carson River as part of the U.S. Geological Survey National Stream-Quality Accounting Network (NASQAN) Program using standard U.S. Geological sampling procedures (U.S. Geological Survey, 1977, Chapters 1 and 5).

Ground water was sampled during this study using protocols described by Hardy and others (1989), which included purging wells by using positive displacement pumps and monitoring selected waterquality parameters until stable readings were obtained. Most samples collected during this study were analyzed by the U.S. Geological Survey National Water 
Quality Laboratory in Arvada, Colorado, by use of the methods described by Thatcher and others (1977), Wershaw and others (1987) and Fishman and Friedman (1989); radon was analyzed by a contractor to the laboratory. Stable isotopes of water were analyzed at a U.S. Geological Survey laboratory in Menlo Park, California.

On-site measurements included $\mathrm{pH}$, water temperature, specific conductance, dissolved oxygen, alkalinity, electrochemical potential (Eh), and, at some sites, sulfide. These measurements, except for alkalinity and sulfide, were made in a flow-through cell. The $\mathrm{pH}$ meter and electrode system was calibrated at each site by using two buffer solutions ( $\mathrm{pH} 7$ and 4 or 10) that bracketed the expected $\mathrm{pH}$ of the sample. Water temperature was measured with a calibrated mercury thermometer. The specific conductance meter was calibrated at each site with a standard potassium chloride solution that was about the same conductance as the sample. Dissolved oxygen was measured with a calibrated polarographic oxygen-sensing electrode. Alkalinity was determined immediately after sample collection by incremental titration with standardized sulfuric acid (either 0.16 or 1.6 normal), from which carbonate and bicarbonate were calculated (Barnes, 1964). Eh was determined using the method of Thorstenson and others (1979) that employs a platinum-calomel combination electrode. Sulfide was determined by a specific-ion electrode using the method of Lico and others (1982).

\section{Surface Water}

Surface water is a major source of recharge to aquifers in the study area, thus the chemical composition of surface water is important in understanding physical and chemical processes in the ground-water aquifers. The data used to characterize surface-water quality were collected at the Fort Churchill gage during calendar years 1980-90 as part of the U.S. Geological Survey NASQAN Program. The chemistry of the Carson River at Fort Churchill (fig. 2B), on an equivalent basis, is generally not dominated by any one cation or anion; although in a few samples bicarbonate was the dominant anion. Thus, water in the Carson River is a mixed cation-anion type. Even though changes in streamflow do not appear to affect the relative proportion of cations or anions to a large extent, concentrations of nearly all major ions in the river are affected by changes in flow.

The change in ion concentrations of the Carson River in relation to streamflow was examined using a nonparametric Mann-Whitney test. The nonparametric test rather than a parametric statistical test was used because water-quality data either do not have a normal distribution, or they exhibit nonconstant variance. The Mann-Whitney test compares the magnitude of the samples drawn from two populations in much the same way as a t-test may be used to compare the means of two such samples (Conover, 1980, p. 213-228). Boxplots, like those in figure 7 (Tukey, 1977, p. 39-41), are used to display summary statistics showing the distribution of reported concentrations for selected constituents. Statistical components are represented visually by features known as "boxes" and "whiskers," which can be described as follows: The box defines the spread of the middle 50 percent of the data (concentrations that lie between the 25 th and 75 th percentiles); the median value (the 50th percentile) is shown by a horizontal line within the box; vertical lines, which extend from the ends of the box to the maximum and minimum values, are called whiskers.

The chemistry of river water at Fort Churchill was divided into three groups on the basis of streamflow duration. The first group includes water-chemistry samples for low streamflows, flows less than or equal to 33.5 cubic feet per second $\left(\mathrm{ft}^{3} / \mathrm{s}\right.$; the 25 th percentile). The second group includes water-chemistry samples for medium streamflows, flows greater than $33.5 \mathrm{ft}^{3} / \mathrm{s}$ and less than $461 \mathrm{ft}^{3} / \mathrm{s}$ (the 25 th to 75 th percentile). The third group includes waterchemistry samples for high streamflows, flows equal to or greater than $461 \mathrm{ft}^{3} / \mathrm{s}$ (the 75 th percentile). The median concentration of all major ions was greatest at low flows and least at high flows (fig. 7). All majorion concentrations are statistically different at the alpha $=0.01$ level among the three flow groups. The high ion concentrations for low flow may reflect evaporative concentration of surface water, ground water with high dissolved-solids concentration discharging into the river, and upstream irrigation return flows with high dissolved-solids concentration. The low ion concentrations for high flow indicate dilution of surface water by snowmelt and storm runoff.

Concentrations of dissolved ammonium $\mathrm{NH}_{4}{ }^{+}$, as nitrogen), dissolved nitrate $\left(\mathrm{NO}_{3}{ }^{-}\right.$, as nitrogen), and dissolved orthophosphate $\left(\mathrm{PO}_{4}^{-3}\right.$, as phosphorus) were 


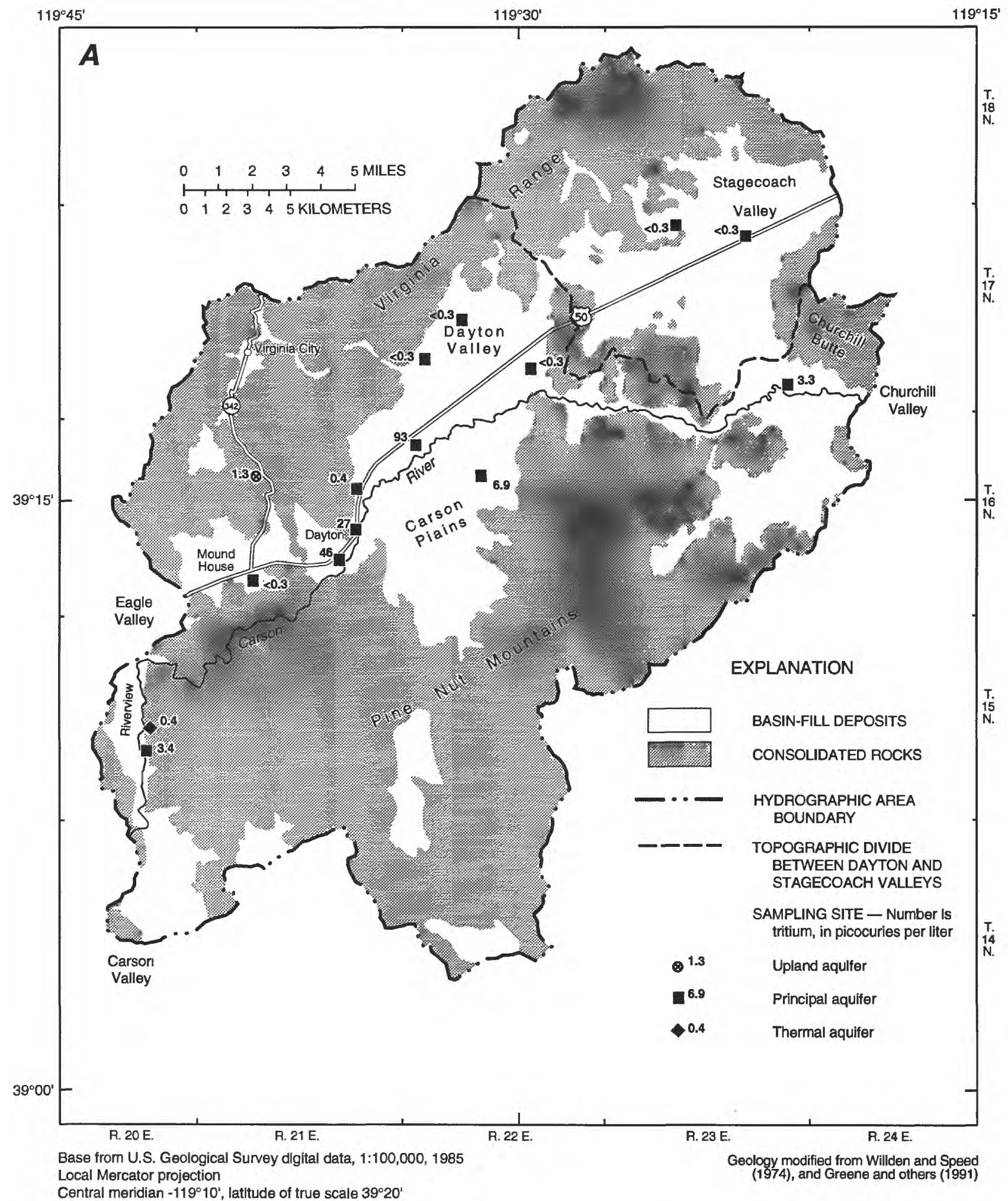

Figure 6. Tritium concentration of ground-water samples from $A$, Dayton and Stagecoach Valleys, and $B$, Churchill Valley. 


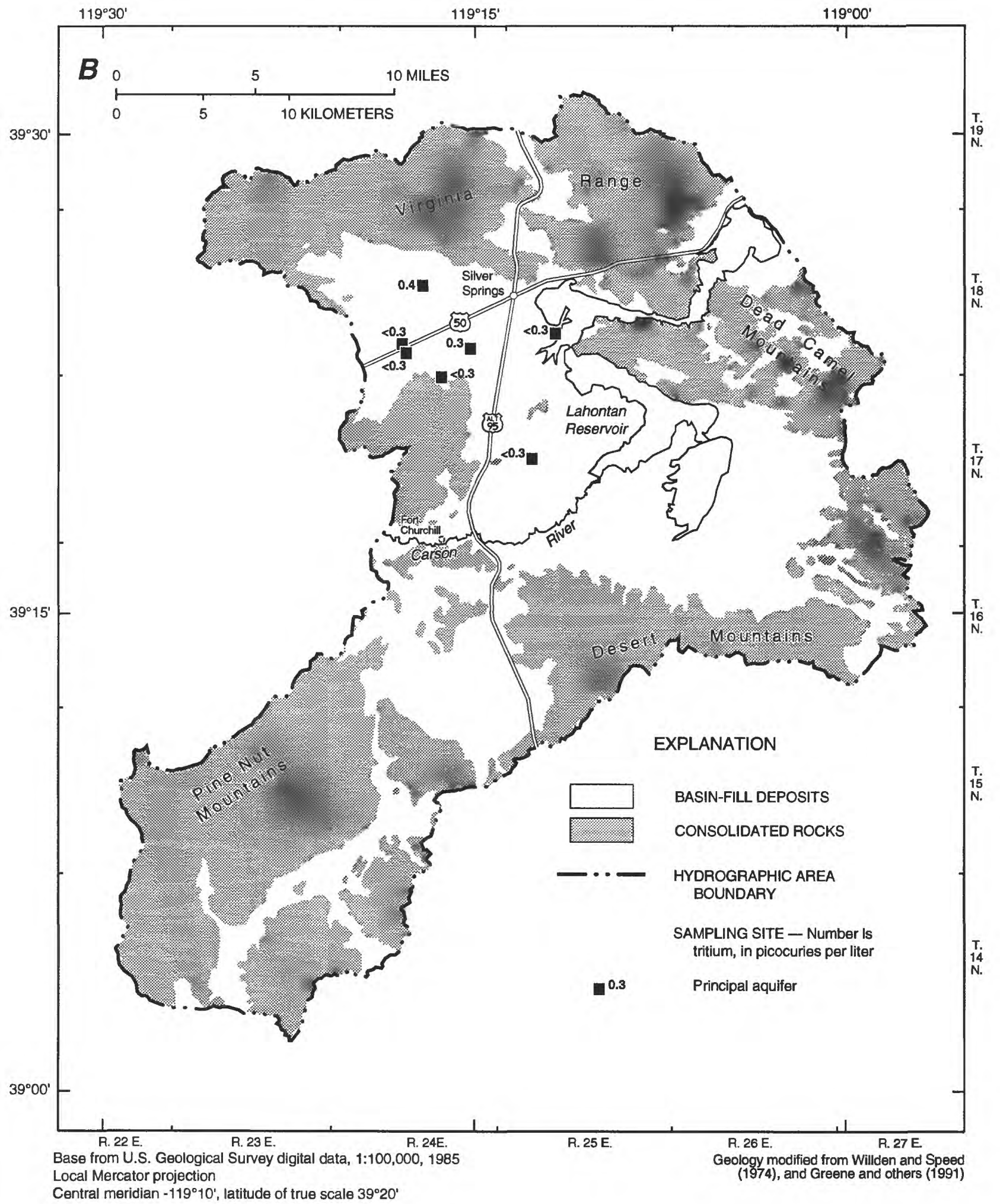

Figure 6.-Continued 

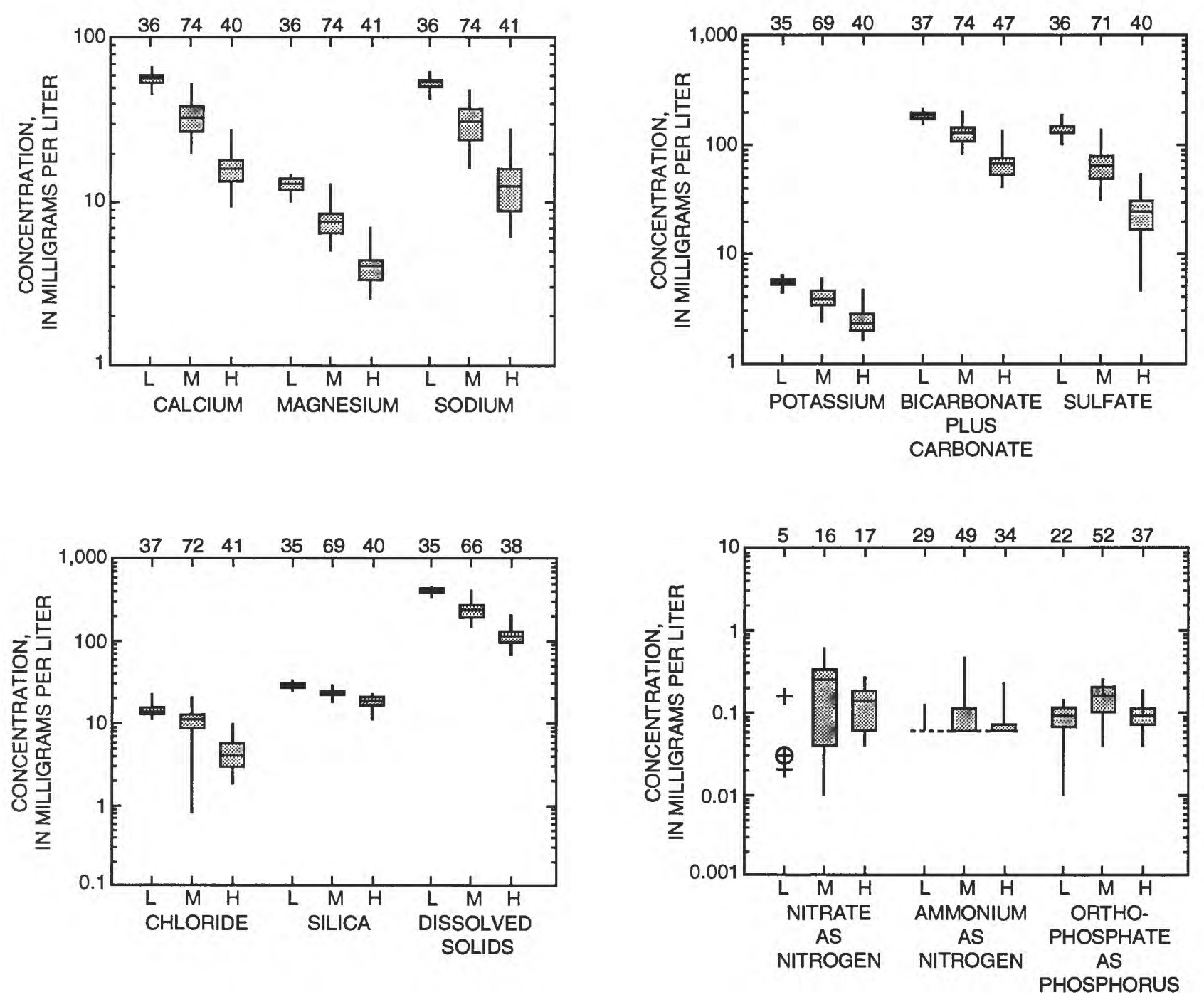

\section{EXPLANATION}

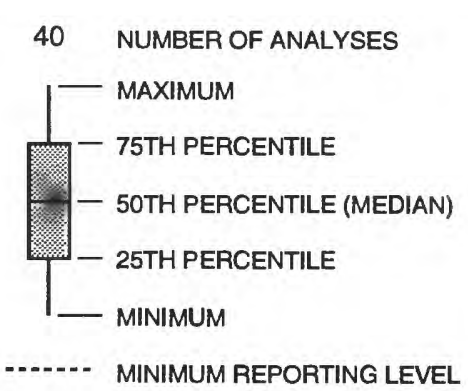
$+\quad$ Single value
$\oplus$ Multiple VAlue
L LOW FLOW ( $\leq 33.5$ CUBIC FEET PER SECOND)
M MEDIUM FLOW ( $>33.5$ to $<461$ CUBIC FEET PER SECOND)
H HIGH FLOW ( 2461 CUBIC FEET PER SECOND)

Figure 7. Major-ion and nutrient concentrations for water samples collected during low, medium, and high flows of the Carson River at Fort Churchill for calendar years 1980-90. 
low (less than 1 milligram per liter (mg/L)) for all samples collected from the Carson River at Fort Churchill, despite being downstream from urban, agricultural, and pasture land in Carson, Eagle, and Dayton Valleys and the Dayton sewage treatment facility (fig. 7). Measured dissolved orthophosphate concentrations may be lower than actual concentrations if the samples contained high sediment or organic carbon concentrations (David Rickert, U.S. Geological Survey, written commun., 1992). Median concentration of nitrate was not statistically different between any of the flow groups, ammonium was statistically different between the low flow and the other two groups, and orthophosphate was statistically different between the low and middle and middle and high flow groups at the alpha $=0.01$ level. Nitrate concentrations did not exceed Nevada's primary drinking-water standard of $10 \mathrm{mg} / \mathrm{L}$ as nitrogen.

The chemistry of the Carson River at different flows is important where river water recharges the basin-fill aquifer. The interaction of surface and ground water was discussed in the section "Occurrence and Movement of Ground Water and Isotope Hydrology."

\section{Ground Water}

Characterizations of regional ground-water quality are usually constrained by the areal and vertical distribution of the sampling sites and the temporal and parametric variations of the samples. Although the selection of sampling sites for this study (fig. 2) was made on the basis of an overall design for a study of the entire Carson River Basin (Welch and Plume, 1987) by using a nationally consistent quality-assurance plan that was designed to focus on principal water resources (Mattraw and others, 1989), the resultant data base still has limitations that constrain interpretation of the data. The data base contains information for 60 sampling sites, but only 1 site was sampled for the thermal aquifers, 3 for shallow aquifers, and 7 for upland aquifers. In contrast, analyses of water from the principal aquifers are available for 48 sites. One sample was taken of water on a playa surface (site 20) and was not used in characterizing ground-water quality. Location and basic information on the wells is included in a report by Whitney (1994).
Most of the data used to characterize groundwater quality were collected in 1988-89 during the NAWQA pilot program. In addition, data from analyses of 24 samples collected in 1981-83 by Harrill and others (1992) were used. Some wells and springs were sampled more than once. To avoid bias toward sites that have been repeatedly sampled, only the most recent analyses were used in the spatial description of ground-water quality. The most recent analyses were used because analytical precision and accuracy generally have improved with time.

Another bias in the data set was introduced by water uses at the sampled wells. Water from wells tapping the principal aquifers generally is used for drinking water or irrigation and may represent a biased sample because public water-supply wells that produce poor-quality water are generally abandoned or never put into service. Consequently, using water-supply wells to sample the principal aquifers can result in a greater percentage of wells pumping water that meets the drinking-water standards than is truly representative of the entire aquifer system. Wells tapping the principal aquifers also have variable open intervals, from less than 30 to more than $100 \mathrm{ft}$, and some have an annulus filled with gravel. Because all of the wells tapping the principal aquifers are water-supply or irrigation wells, the open intervals generally are in the most productive parts of the aquifer. Thus, the water quality of the finer-grained, low permeability parts of the principal aquifers is probably not well represented by the available data. The available wells also tap only the upper part of the principal aquifer system-the wells sampled are generally less than $400 \mathrm{ft}$ deep, whereas the basin fill has a maximum thickness of about 3,000 ft. Because of these limitations, the data from this study are believed to be more representative of the ground water actually used for public supplies and irrigation from the principal aquifers than of all ground water in the study area.

Aquifers are the major source of drinking water in the study area, so the Nevada State drinking-water standards for public-water supplies provide an appropriate reference for evaluating the quality of ground water in these valleys. The standards consist of primary maximum contaminant levels (MCL's), secondary maximum contaminant levels (SMCL's), and secondary preferred standards (SPS's). The MCL's, which are health related and Federally and State enforceable, specify maximum permissible concentrations of constituents in water delivered to the user of a 
public water-supply system. The SMCL's relate to the aesthetic quality, such as color and taste of the water and are not Federally enforceable. The SPS's may be applied if the concentrations are locally attainable-if not, then the SMCL's apply (Nevada Bureau of Consumer Health Protection Services, 1980, p. 8; Jeffery

A. Fontaine, Nevada Bureau of Consumer Health Protection Services, oral commun., 1989). The MCL's, SMCL's, and SPS's were adopted by the State of Nevada in 1988. The MCL's adopted by the State for inorganic constituents are equal to the values established by the U.S Environmental Protection Agency (1986a). In general, the concentrations adopted by the State as SPS's follow the guidelines established by the U.S. Environmental Protection Agency (1986b). Some of the constituents that have SMCL's adopted by the State also have SPS's and, except for fluoride, the SMCL's are greater than the SPS 's.

\section{Major Inorganic Constituents}

Samples were assigned as upland, shallow, principal or thermal as previously defined in the section "Occurrence and Movement of Ground Water and Isotope Hydrology." The results of a Kruskal-Wallis nonparametric analysis of variance (Conover, 1980, p. 229-237) show concentrations of calcium, magnesium, sodium, potassium, bicarbonate, sulfate, and chloride are not statistically different among the different aquifer types (at the alpha $=0.05$ level), except that chloride is higher in principal aquifers than in upland aquifers.

The variability in the chemical composition, dissolved-solids concentrations, and $\mathrm{pH}$ of ground-water samples from the study area is displayed on a single diagram (fig. 8). The diagram consists of five fieldstwo triangular and three rectangular (Zaporozec, 1972, p. 38). Each chemical analysis is plotted as five points on the diagram. In combination, the five points provide a general idea of the overall chemical composition of the water. The relative proportions of major cations (calcium, magnesium, and sodium plus potassium) and anions (sulfate, chloride, and carbonate plus bicarbonate) are shown in the left and upper triangles, respectively. The $\mathrm{pH}$ and dissolved-solids concentrations are plotted in the bottom and right rectangles, respectively. The primary advantage of this type of diagram is that it provides a visual characterization, on a single illustration, of eight major chemical constituents, $\mathrm{pH}$, and dissolved-solids concentration of the ground water. The principal application of this type of diagram is to examine the grouping of data points in each of the five individual triangular or rectangular areas. The arrows in figure 8 show how the cation and anion points for a single analysis are projected from the cation and anion triangles to the central rectangle and then to the $\mathrm{pH}$ and dissolved-solids rectangles. The central rectangle is a transitional area to connect the four outside triangular and rectangular plots.

The concentration of dissolved solids in groundwater samples ranges from 200 to 1,700 milligrams per liter $(\mathrm{mg} / \mathrm{L})$, with a median concentration of $380 \mathrm{mg} / \mathrm{L}$ (table 3). Five samples exceeded Nevada's SMCL for dissolved solids of $1,000 \mathrm{mg} / \mathrm{L}$ (table 3 ). Four of these 5 samples were from Dayton Valley and 1 sample was from northern Churchill Valley (site 57, fig. $2 B$ ). The $\mathrm{pH}$ of ground-water samples ranges from 6.6 to 8.3. Water in the principal aquifers generally had the highest $\mathrm{pH}$. Mixed cation bicarbonate and calcium bicarbonate type waters were present in all three aquifers, but only 3 of the 12 samples from the principal aquifers in Dayton Valley contained this type of water. Calcium and sodium sulfate type waters were in 9 of the 12 wells in Dayton Valley, 4 wells clustered in western Stagecoach Valley (sites 23, 31, 33, and 34; fig. 2A), and 4 wells in Churchill Valley (sites 49, 54, 57, and 58; fig. $2 B$ ). The water samples containing sulfate as a major anion also generally contain the highest concentrations of dissolved solids.

The minimum, maximum, and median concentrations of the major ions are given in table 3. Median and maximum concentrations reflect the generally dilute ground water in the study area. Five samples equaled or exceeded the Nevada State SMCL of $500 \mathrm{mg} / \mathrm{L}$ for sulfate and 12 samples equaled or exceeded Nevada's SPS of $250 \mathrm{mg} / \mathrm{L}$ for sulfate (table 3). All samples were below the Nevada State SMCL and SPS for chloride and magnesium.

\section{Modellng of Geochemlcal Reactlons}

Major constituents dissolved in ground water in the study area are the result of reactions of water with minerals and gases in the aquifer. Constituents are added to the water by the dissolution of aquifer minerals and carbon dioxide in the soil zone; constituents are removed by the precipitation of minerals, formation of clay minerals by incongruent dissolution, and exsolution of carbon dioxide. In addition, some constituents can be removed or added to the water by cation 
NOTE: TRILINEAR PLOTS

INDICATE PERCENTAGES, ON

BASIS OF MILLIEQUIVALENTS

PER LITER
(1)
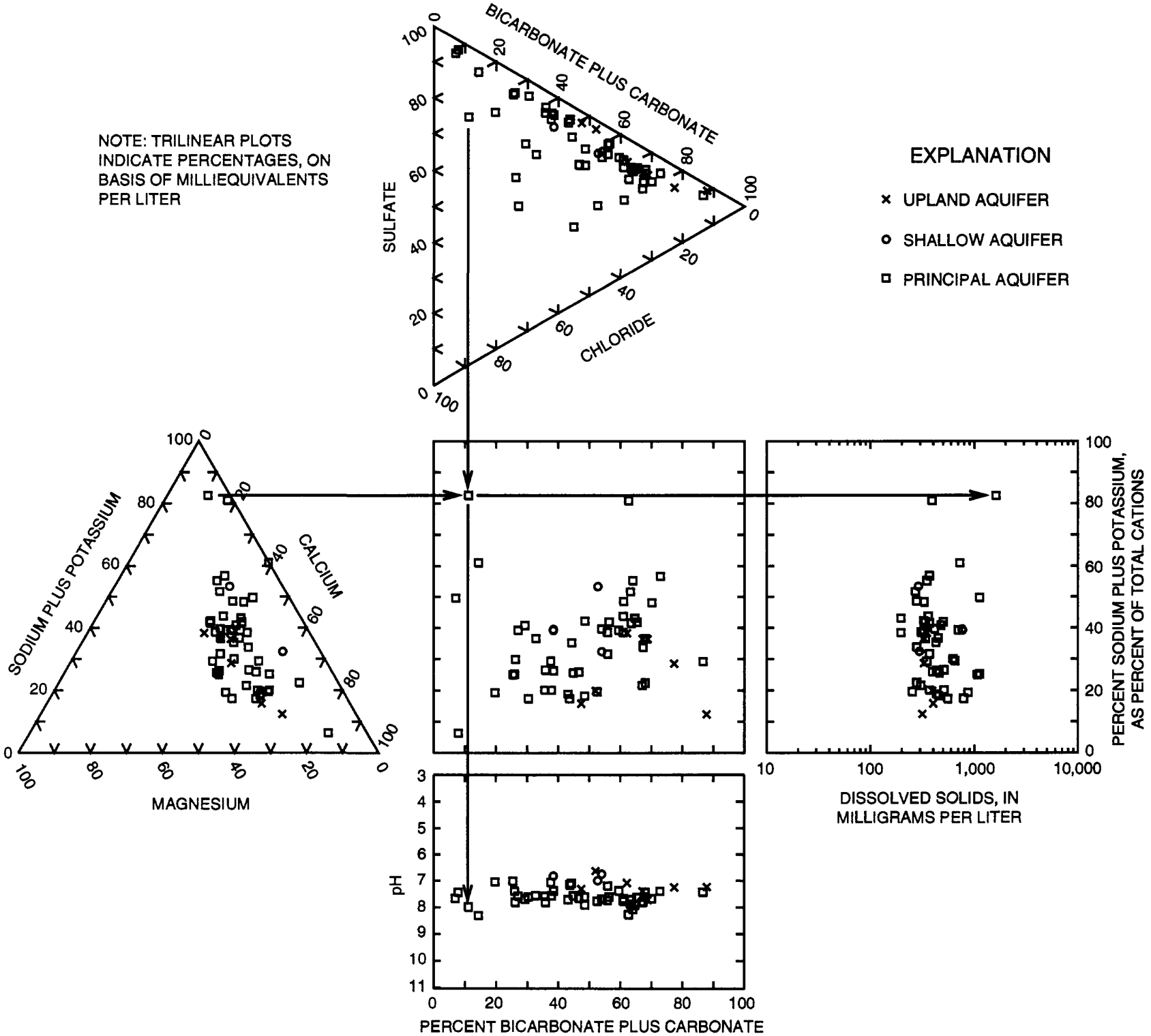

EXPLANATION

× UPLAND AQUIFER

- SHALLOW AQUIFER

口 PRINCIPAL AQUIFER

Figure 8. Chemical composition of ground-water samples from the Dayton, Stagecoach, and Churchill Valleys. Arrows show how data points for a single analysis are projected from triangles to rectangles.

exchange. Constituent concentrations can also change by mixing waters. These processes can be represented as a set of chemical reactions, commonly referred to as a geochemical model. A geochemical model for a ground-water system can be evaluated using a massbalance approach that incorporates chemical and isotopic data for ground water, mineralogy of the aquifer matrix, thermodynamic data for phases (minerals, gases, and amorphous phases), and hydrologic information (Plummer and others, 1983). One common approach is the formulation of geochemical models along a ground-water flow path which yields a different model for the different segments of the flow path between the sampling locations. This approach was not used for ground water in the study area, because flow paths are not well defined and the wells do not generally draw water from discrete depths owing to long screened intervals commonly used in supply wells.

The approach used in this study assumed that the water chemistry in the principal aquifers can be described by a common set of chemical reactions. 


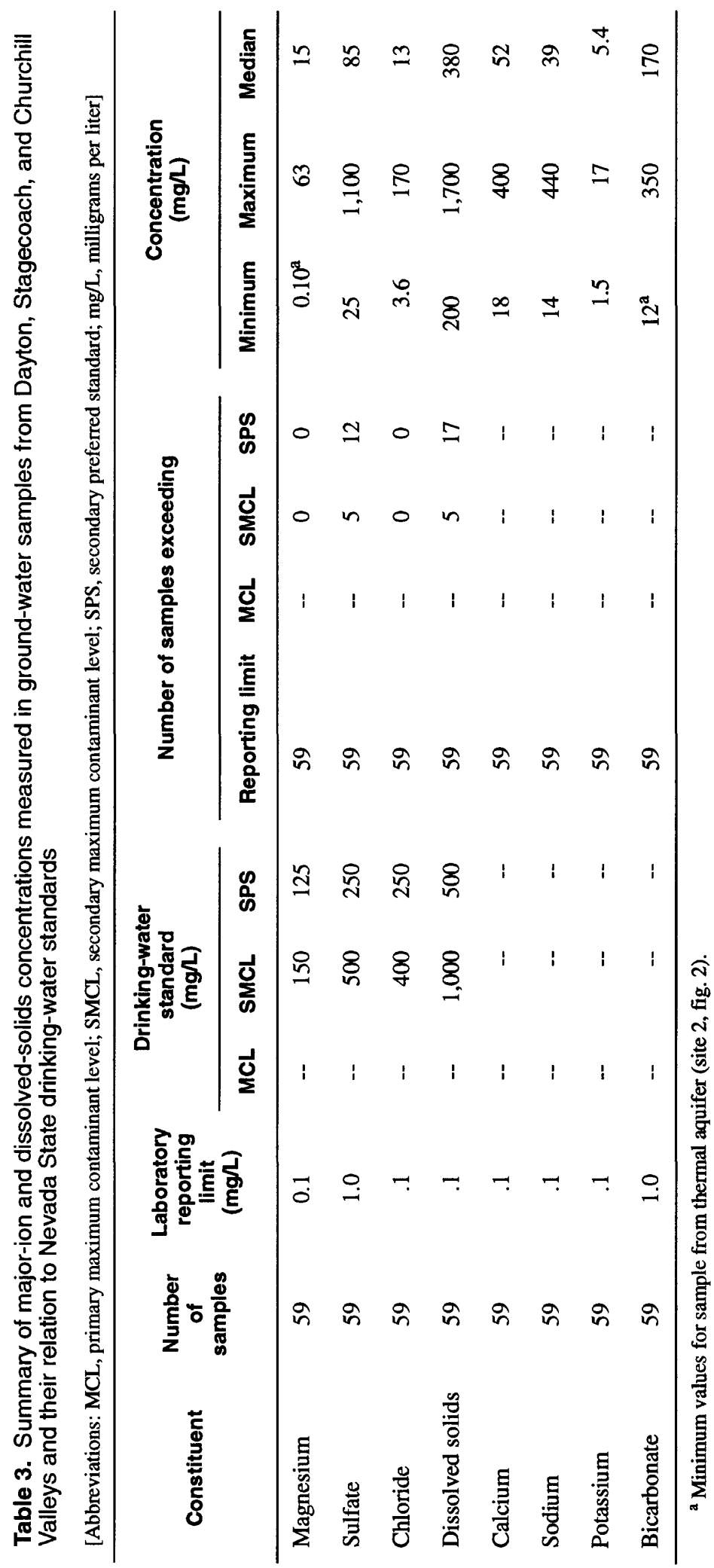


This approach resulted in development of geochemical models consistent with (1) mineralogic data for a limited set of samples collected in the shallow subsurface (less than $50 \mathrm{ft}$ deep) in the study area, (2) the bulk chemistry of sediments in the study area, (3) the chemical and isotopic compositions of the ground water, and (4) thermodynamic calculations of mineral equilibria. From the specific geochemical models, general geochemical models are developed to describe the water chemistry in the principal aquifers for a minimum of 70 percent of the samples in the modeled area, and in which the total mass transfer of all constituents into the water is less than 20 millimoles per kilogram $(\mathrm{mmol} / \mathrm{kg})$. A general model is developed on the basis of a set of specific models that consist of reactions consistent with the observed water chemistry and aquifermatrix mineralogy.

General geochemical models were evaluated for 10 samples in Dayton Valley and 27 samples in Stagecoach and Churchill Valleys. Samples from Stagecoach and Churchill Valleys were grouped together because of the small number of samples in Churchill Valley (7 samples), the closeness of the wells in northeast Churchill Valley to the wells in Stagecoach Valley, and their similar hydrogeologic setting. The most dilute water in the recharge areas (site 3) was used as the initial water for modeling the reactions. An average chemical composition for all samples in the recharge areas could have been used as the initial water, but fewer general geochemical models would result because this average initial water has higher average ion concentrations than water from site 3 .

Samples from wells adjacent to the Carson River with heavier deuterium compositions than water in the adjacent principal and shallow aquifers were considered to have derived a significant part of their water from the river. A Mann-Whitney statistical test showed that ground water containing Carson River water is statistically different from the water in principal aquifers at the alpha $=0.05$ level for deuterium, dissolved solids, chloride, magnesium, silica, temperature, and $\mathrm{pH}$. Consequently, the river-influenced samples (sites $1,8,9,11,19,39,40,47,53,56,58,59$, and 60 ; fig. 2) were not included in the models with the rest of the samples from principal aquifers. One sample, from site 12 adjacent to the Carson River in Dayton Valley, contained $93 \mathrm{pCi} / \mathrm{L}$ of tritium and had an isotope composition (-119 permil) lighter than any measured for the river ( -108 permil) and lighter than the median value of samples in the Dayton Valley principal aquifer
(-113 permil). Although a major part of this water may have been recently recharged water, the sample has been included with the Dayton Valley principal-aquifer water because of its light isotopic composition and chemical composition similar to that of samples from the principal aquifers.

No unique geochemical model exists for a set of water-chemistry data, but the individual mass-balance solutions are unique. These solutions require that the number of phases (minerals, gases, and cation exchange) be equal to the number of elements (major ions) used in the model. Minerals used in development of the geochemical models were discussed in the section "Mineralogic Composition of the Basin-Fill Sediments" and are listed in table 2. The chemical composition of phases used in the geochemical models are given in table 4. Plagioclase grains in the basin-fill sediments are dominated by andesine and oligoclase with an average chemical composition of $\mathrm{Ca}_{0.34} \mathrm{Na}_{0.66} \mathrm{Al}_{1.34} \mathrm{Si}_{2.66} \mathrm{O}_{8}$ (table 2). Plagioclase grains make up 36 percent of the total mineral composition of the sediment samples-19 percent as separate grains and 17 percent within basaltic lithic fragments. The plagioclase in basalt is probably more calcic than the plagioclase grains (Deer and others, 1966, p. 335); thus, a chemical composition of $\mathrm{Ca}_{0.4} \mathrm{Na}_{0.6} \mathrm{Al}_{1.4} \mathrm{Si}_{2.6} \mathrm{O}_{8}$ was used for plagioclase in the geochemical modeling. The composition used for biotite is the same as previously used in weathering models for the Sierra Nevada (table 2, from Garrels and MacKenzie, 1967). The sodium end member is used for the beidellite clay (montmorillonite) composition. Sodium and chloride are assumed to enter ground water in equivalent amounts from evaporative salts or fluid inclusions. Carbon dioxide was included as a phase because of its presence as a gas in the unsaturated zone and the presence of organic matter in the aquifer. The exchange of divalent cations (calcium and magnesium) in the water for monovalent cations (sodium and potassium) on clays was used because of the presence of montmorillonite clays in the basin-fill sediments.

Aluminum was assumed to be conservative in the models; that is, the concentration of aluminum in the initial and final waters would be the same.

Illite was identified in basin-fill sediments, but was not included as a phase in the geochemical models because it does not generally form or dissolve in nonthermal environments (Graf von Reichenbach and Rich, 1975) that are present in most of the study area. Illite in the study area probably originated during the 
late stages of igneous rock formation. Pyrite is present in mineralized areas in mountains surrounding the basin-fill aquifers, but was not included as a phase in the models because of the common occurrence of gypsum and gypsite in the study area (Bonham, 1969; and Moore, 1969). With phases limited to the number of elements in the geochemical models, gypsum was chosen as a more likely source of sulfate than pyrite. However, the same models result when using pyrite in place of gypsum as a sulfate source, except, because pyrite $\left(\mathrm{FeS}_{2}\right)$ does not contain calcium and gypsum does, less calcium would be dissolved in the water resulting in less calcite precipitation. This would also result in more carbon dioxide exsolution because less carbon would be removed by calcite precipitation.

Results of geochemical model simulations, using the computer program "BALANCE" (Parkhurst and others, 1982), are given in figures 9 and 10 . BALANCE calculates the average amounts of mass input and output for all possible combinations of the phases given in table 4. General geochemical models were developed for the study area.

In all three valleys, some of the samples were not included in a general geochemical model. The geochemical models for these samples include a change in chloride between the initial and final water chemistry that is greater than the change in sodium (in millimoles per kilogram). Thus, these waters may evolve from a more dilute water, or one with a different ratio of sodium to chloride, than water at site 3 (site 3 contains 7 times more sodium than chloride on an equivalent basis), or site 3 water is not representative of recharge chemistry for these samples. Another possibility is that sodium has been removed (adsorbed by clays) or a chloride salt with a cation other than sodium is being dissolved, because all these waters contain chloride in greater concentration (in equivalents) than sodium. General geochemical models for the study area have most of the same processes, with the exception that models for Dayton Valley include the formation of sodium beidellite and the exchange of calcium in the water for sodium on clays, whereas the models for Stagecoach and Churchill Valleys include precipitation of silica. These similar processes are (1) the dissolution of plagioclase feldspar, sodium chloride, gypsum (or pyrite), potassium feldspar, and biotite; (2) precipitation of calcite; (3) formation of kaolinite; (4) exchange of relatively small amounts of calcium and magnesium in the water for potassium on aquifer minerals (or the uptake of potassium by clays); and (5) gain or loss of carbon dioxide.

Median values for the mass transfer of phases for general geochemical models of ground-water samples from Dayton Valley are given in figure 9 and of groundwater samples from Stagecoach and Churchill Valleys are given in figure 10. The amounts of mass transfer are the molar mass contributed or removed from the ground water by the processes. Positive values indicate dissolution or cation exchange and negative values indicate gas and mineral precipitation, formation, or exsolution.

The major sources of dissolved constituents in ground water in Dayton Valley are the dissolution of gypsum (or pyrite), plagioclase feldspar, chlorite, and sodium chloride, and the exchange of calcium in the water for sodium on clays. Minor sources of dissolved constituents include dissolution of carbon dioxide (two models), potassium feldspar (one model); and biotite (one model); and the exchange of calcium or magnesium in the water for potassium on aquifer materials (two models). The primary processes that result in the removal of dissolved constituents from the ground water are the precipitation of calcite, and the formation of sodium beidellite, or kaolinite. Lesser amounts of carbon dioxide appear to be lost from the ground water (two models; fig. 9).

The major sources of dissolved constituents in ground water in Stagecoach and Churchill Valleys are the dissolution of plagioclase feldspar, gypsum, (or pyrite) and sodium chloride. Minor sources of dissolved constituents include dissolution of potassium feldspar and biotite (one model) and the exchange of calcium or magnesium in the water for potassium on aquifer materials (two models). Formation of kaolinite and precipitation of calcite and silica remove dissolved constituents from ground water. All the models suggest that a small amount of carbon dioxide is removed from the ground water. One model indicates the precipitation of chlorite, which may be unlikely given the low water temperatures measured in the principal aquifers; this model (fig. 10) may be unsatisfactory.

The processes of dissolution, precipitation, and formation of minerals agree well with thermodynamic calculations made using the computer program "WATEQ4F" (Ball and others, 1987) and with the observed mineralogic composition of the aquifers. 
Table 4. Phases (minerals, gases, and cation exchange) and chemical compositions included in geochemical models of ground water for Dayton, Stagecoach, and Churchill Valleys

[Constraints: D, the mineral may dissolve, but not precipitate; F, all models include this phase-the phase is "forced" into the set of models considered; $\mathrm{P}$, the mineral may precipitate, but not dissolve; $\mathrm{N}$, no constraints]

\begin{tabular}{|c|c|c|c|}
\hline Phase & Chemical composition & Phase selection rationale & Constraints \\
\hline Biotite & $\mathrm{KMg}_{3} \mathrm{AlSi}_{3} \mathrm{O}_{10}(\mathrm{OH})_{2}$ & $\begin{array}{l}\text { Identified in thin section; mostly altered } \\
\text { to chlorite. }\end{array}$ & D \\
\hline Calcite & $\mathrm{CaCO}_{3}$ & $\begin{array}{l}\text { Identified in thin section; present as coat- } \\
\text { ings on mineral grains. }\end{array}$ & $\mathrm{N}$ \\
\hline Carbon dioxide & $\mathrm{CO}_{2}$ & $\begin{array}{l}\text { Ubiquitous; atmospheric, root respira- } \\
\text { tion of } \mathrm{C}_{4} \text { plants, such as Atriplex and } \\
\text { possibly oxidation of sedimentary } \\
\text { organic matter. }\end{array}$ & $\mathbf{N}$ \\
\hline Chlorite & $\mathrm{Mg}_{5} \mathrm{Al}_{2} \mathrm{Si}_{3} \mathrm{O}_{10}(\mathrm{OH})_{8}$ & $\begin{array}{l}\text { Common alteration product of feldspars, } \\
\text { biotite, pyroxene, and hornblende as } \\
\text { seen in thin section; presence confirmed } \\
\text { by X-ray diffractometry. }\end{array}$ & $\mathrm{N}$ \\
\hline Exchange & $\mathrm{Ca}-\mathrm{Na}, \mathrm{Ca}-\mathrm{K}, \mathrm{Mg}-\mathrm{K}$ & $\begin{array}{l}\text { Abundant exchange sites are present in } \\
\text { sediment. }\end{array}$ & $\mathrm{N}$ \\
\hline Gypsum & $\mathrm{CaSO}_{4} \cdot 2 \mathrm{H}_{2} \mathrm{O}$ & $\begin{array}{l}\text { Identified in the study area; mined near } \\
\text { Mound House in Dayton Valley } \\
\text { (Moore, 1969). }\end{array}$ & F,D \\
\hline Kaolinite & $\mathrm{Al}_{2} \mathrm{Si}_{2} \mathrm{O}_{5}(\mathrm{OH})_{4}$ & Identified by X-ray diffractometry. & $\mathbf{P}$ \\
\hline Montmorillonite & $\begin{array}{l}\text { Sodium beidellite } \\
\mathrm{Na}_{0.33} \mathrm{~A}_{2.33} \mathrm{Si}_{3.67} \mathrm{O}_{10}(\mathrm{OH})_{2}\end{array}$ & $\begin{array}{l}\text { Presence confirmed by X-ray diffractom- } \\
\text { etry; exact composition unknown; } \\
\text { most abundant clay mineral. }\end{array}$ & $\mathrm{P}$ \\
\hline $\begin{array}{l}\text { Plagioclase } \\
\text { feldspar }\end{array}$ & $\begin{array}{l}\text { Intermediate andesine } \\
\mathrm{Ca}_{0.4} \mathrm{Na}_{0.6} \mathrm{Al}_{1.4} \mathrm{Si}_{2.6} \mathrm{O}_{8}\end{array}$ & $\begin{array}{l}\text { Present as detrital grains and as compo- } \\
\text { nents in volcanic and sedimentary lithic } \\
\text { fragments; compositions range from } \\
\text { albite to labradorite. }\end{array}$ & F,D \\
\hline $\begin{array}{l}\text { Potassium } \\
\text { feldspar }\end{array}$ & $\mathrm{KAISi}_{3} \mathrm{O}_{8}$ & $\begin{array}{l}\text { Identified in thin section and by } \mathrm{X} \text {-ray } \\
\text { diffractometry; slight chlorite and } \\
\text { sericite alteration. }\end{array}$ & D \\
\hline Silica & $\mathrm{SiO}_{2}$ & Quartz grains are present in thin section. & $\mathrm{N}$ \\
\hline Sodium chloride & $\mathrm{NaCl}$ & Evaporative salts or fluid inclusions. & F,D \\
\hline
\end{tabular}




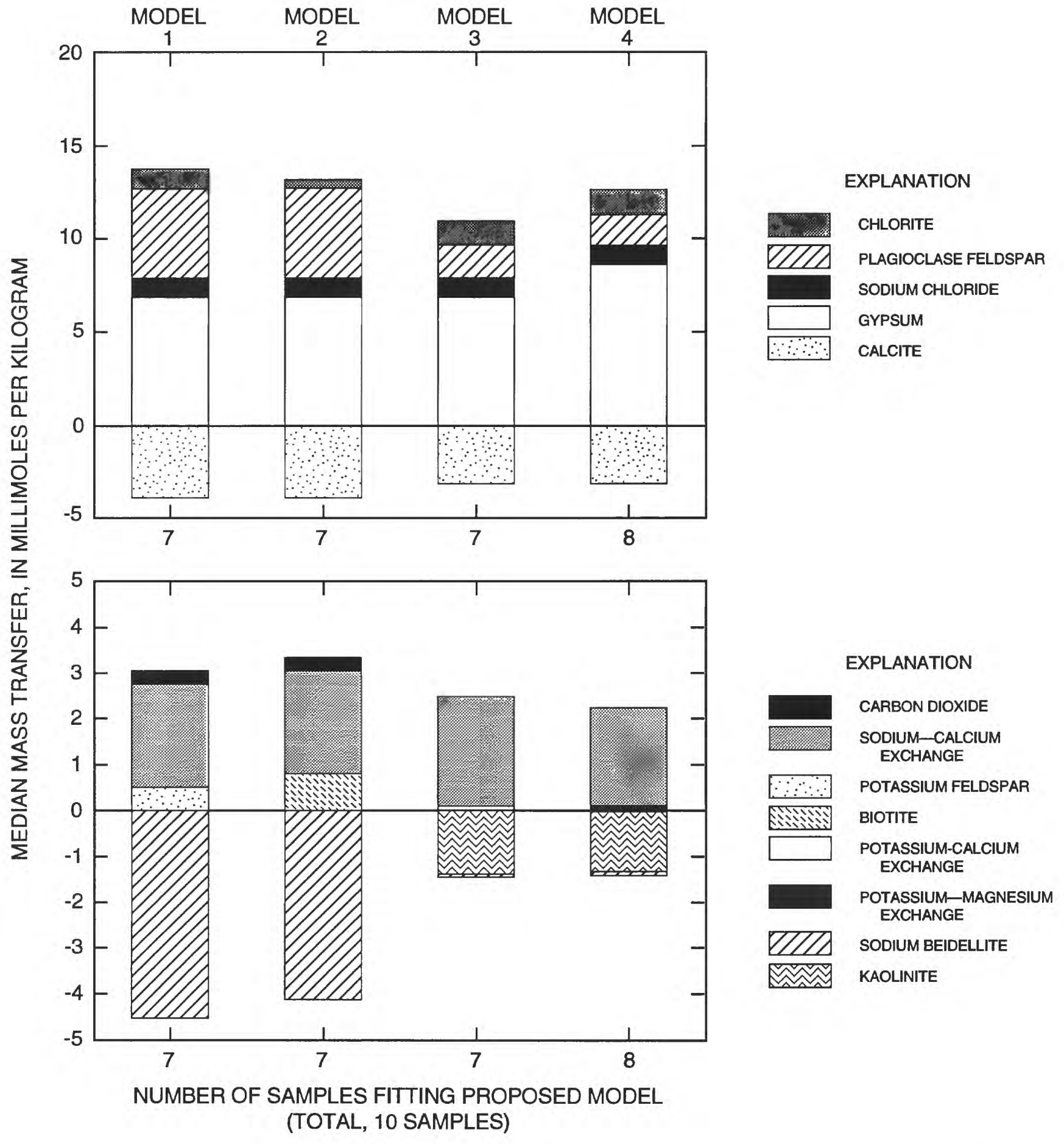

Figure 9. Median amounts of mass transfer for Dayton Valley ground-water samples calculated by geochemical models. Positive mass transfer indicates dissolution or cation exchange; negative value indicates mineral precipitation or formation, or gas exsolution. 


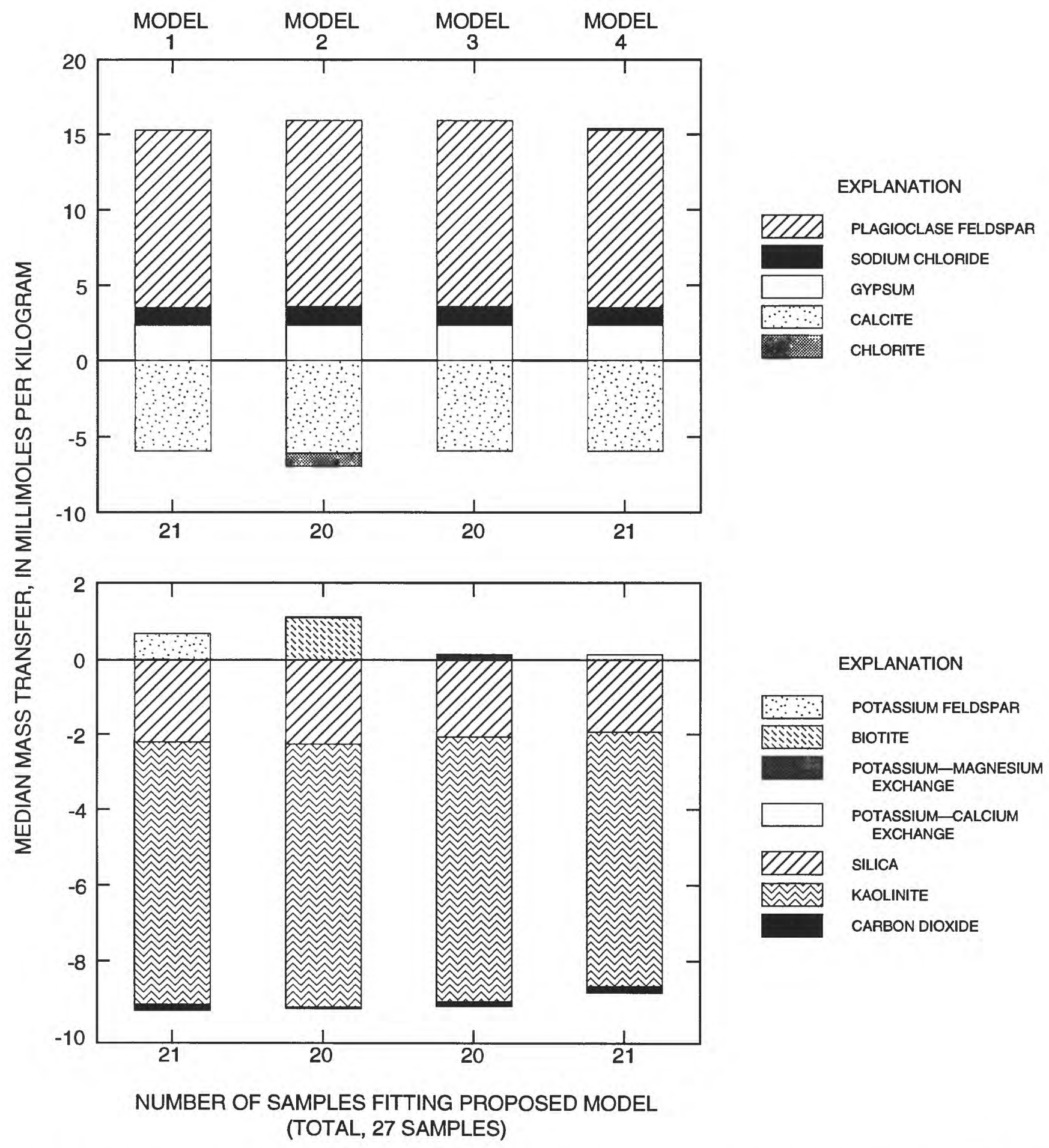

Figure 10. Median amounts of mass transfer for Stagecoach Valley and Churchill Valley ground-water samples calculated by geochemical models. Positive mass transfer indicates dissolution or cation exchange; negative value indicates mineral precipitation or formation, or gas exsolution. 
Saturation indices (the log of the ratio of an ion-activity product to the equilibrium constant) are a measure of the thermodynamic state of a solution with respect to minerals. Positive values indicate the water is saturated relative to a mineral and negative values indicate the water is undersaturated. All ground water in the study area is undersaturated with gypsum and sodium chloride. Thus, if these minerals are present they should dissolve. The saturation index of calcite for samples used in the geochemical models of the study area indicates that the waters are saturated, or close to saturation, with calcite (fig. 11), which indicates that calcite can precipitate from the water. The saturation index of silica for samples used in the geochemical modeling of Stagecoach and Churchill Valleys indicates that the waters are saturated, or close to saturation, with amorphous silica (fig. 12), so silica can precipitate. These thermodynamic calculations are consistent with the geochemical models.

Chemical analysis did not include analysis of aluminum, so saturation indices were not calculated for the aluminosilicate minerals. In addition, because of variability in chemical composition of many of the aluminosilicate minerals, especially clay minerals, calculation of accurate saturation indices is difficult (May and others, 1986). However, microscopic observations and activity diagrams can be used to indicate the dissolution, or formation, of some aluminosilicate minerals identified in the aquifer systems. Plagioclase feldspar is present throughout the aquifer materials; about 10 percent of the feldspar grains show heavy alteration to sericite (table 2). This alteration, and the presence of feldspar grains that have undergone dissolution (Patrick Goldstrand, U.S. Geological Survey, written commun., 1990), indicates that feldspar grains in the aquifer are dissolving. Biotite grains have also undergone alteration and dissolution along edges (table 2). The presence of kaolinite and beidellite in clays in the aquifers indicates that they form stable products of weathering. Activity diagrams also can be used to show the activities for the ground-water samples on the stability fields of common clay minerals (fig. 13). This activity diagram indicates that sodium beidellite and kaolinite would form in the aquifers. Thermodynamic data for beidellite may not be valid in a strict thermodynamic sense (May and others, 1986). However, studies of systems where beidellite is forming have shown that water appears to have stable ionic compositions that correspond to those determined by solubility constants for beidellite (see Drever, 1988, p. 177-188).
Chemical activity ratios for samples in the study area generally plot along slopes consistent with cation exchange reactions (fig. 14), except for 3 samples that contained the highest concentrations of sodium. A ratio of two will result for a water in which the aqueous geochemistry is controlled by the exchange of a divalent for a monovalent cation (Drever, 1988, p. 180-82). This corresponds to a slope of 2 on figure 14. The trend of most of the data is consistent with exchange as a geochemical control on the ratios of the major cations.

All models include the mass transfer (dissolution or exsolution) of $0.3 \mathrm{mmol} / \mathrm{L}$, or less, of carbon dioxide. This small amount of mass transfer may be an artifact of (1) dissolution of soil-zone carbon dioxide; (2) exsolution of carbon dioxide from a spring, well, or sample; or (3) small errors in alkalinity measurements.

In summary, geochemical models are consistent with (1) phases identified in basin-fill sediments of the study area; (2) chemical activity of major cations and silica; (3) saturation indices of calcite and amorphous silica; (4) phase relations for aluminosilicate minerals indicated by activity diagrams; and (5) optical, X- ray diffraction, and scanning-electron microscopy observations of mineral grains in the aquifer sediments. Geochemical models do not yield a unique solution for a geochemical system like that in Dayton, Stagecoach, and Churchill Valleys because the number of reacting phases is greater than the number of elements. However, this approach does yield a set of models that, taken together, represent a general overall model that describes geochemical reactions that can account for the observed major-ion chemistry.

On the basis of deuterium and chemical compositions, some ground-water samples adjacent to the Carson River were determined to be a mixture of river and ground waters, or river water that has reacted with aquifer materials. The effects on the chemical composition of the ground water from the influx of Carson River water into the principal aquifers was examined by mixing Carson River water from low, middle, and high streamflows with water from the adjacent basinfill aquifers (table 5). The median ion concentrations of the river water for each of these three flow regimes were used as endmembers for mixing; medians for sets of samples from the adjacent principal aquifers were used as the other endmembers. For example, median ion concentrations for samples in the principal aquifer of Dayton Valley, that were assumed not to be influenced by Carson River water (sites $5,7,10$, and 12 to 18), were used to represent the ground-water chemistry 


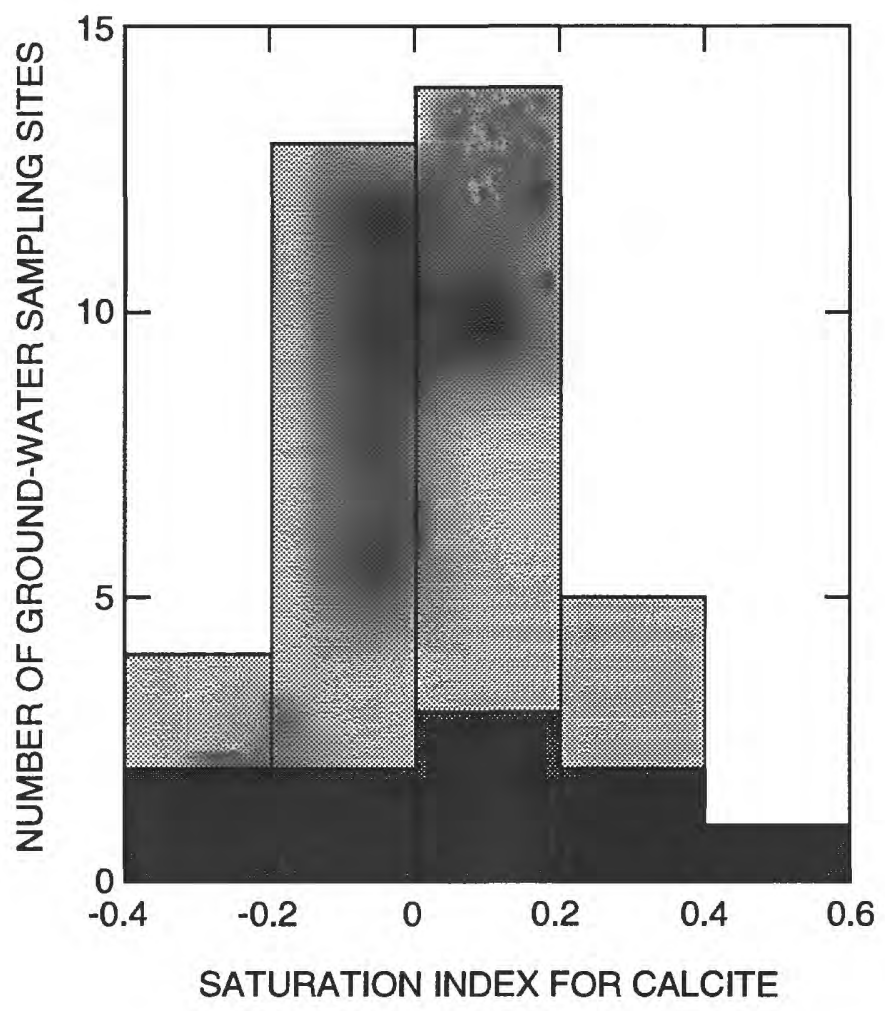

EXPLANATION

STAGECOACH AND CHURCHILL VALLEYS

DAYTON VALLEY

Figure 11. Saturation index of calcite for ground-water samples from principal aquifers in Dayton, Stagecoach, and Churchill Valleys.

for mixing with Carson River water in Dayton Valley. The percentage of each endmember in the mixture was determined for each well using deuterium.

The chemical composition of the mixed water is not generally produced by simply mixing the waters in proportions determined by deuterium content. Although several of the ion ratios are close to one (table 5), which would result from simple mixing, most of the ratios are not, indicating the ion concentrations have been affected by geochemical processes in addition to mixing. Ion ratios greater than one indicate the ion has been added to the mixed water, whereas ratios less than one indicate the ion has been removed from the mixed water. Increases in ion concentrations after mixing are probably caused by mineral and gas dissolution; decreases in ion concentrations are probably caused by mineral precipitation, clay formation, cation exchange, and gas exsolution. Mixed ground waters that contain greater than 95 percent river water (table 5) generally have ion concentrations that are greater than the initial river water. Thus, the river water is undergoing chemical reactions as it infiltrates and flows through the aquifers.

\section{Evaluatlon of Geochemical Models Using Sulfur and Carbon Isotopes}

The stable-isotope composition of dissolved inorganic sulfur and carbon can be used to help evaluate the geochemical models. Changes in the isotopic composition of dissolved inorganic sulfur and carbon can be the result of several processes. These processes include (1) a variation in the amount or isotopic composition of dissolving minerals or of gases equilibrating with the water that contain sulfur and carbon; (2) mineral precipitation and loss of gas; 


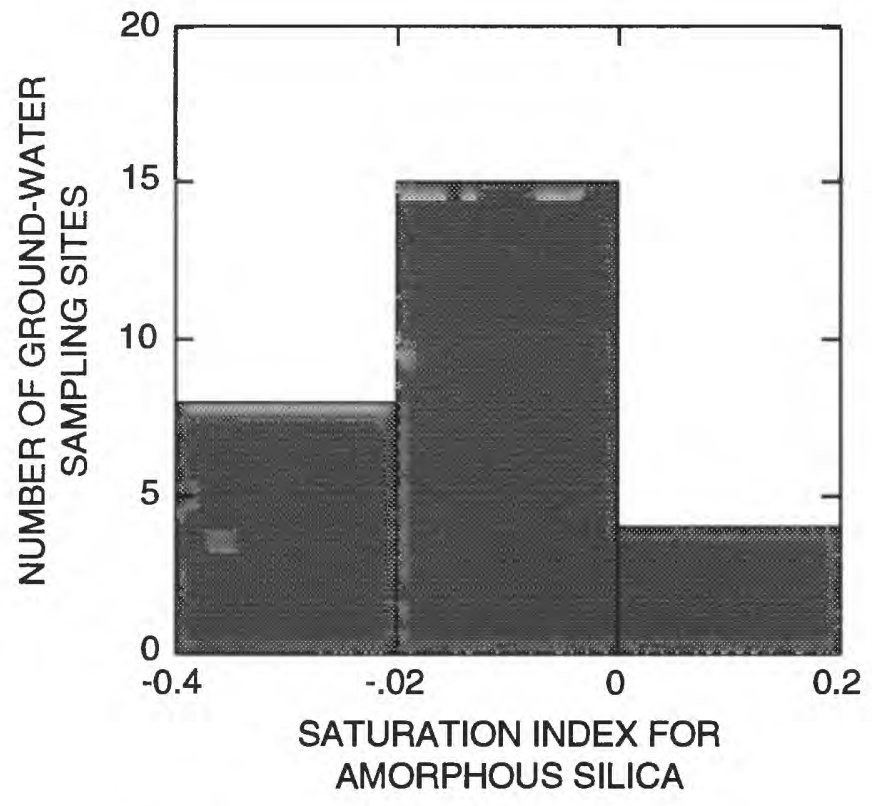

Figure 12. Saturation index of amorphous silica for ground-water samples from principal aquifers in Stagecoach and Churchill Valleys.

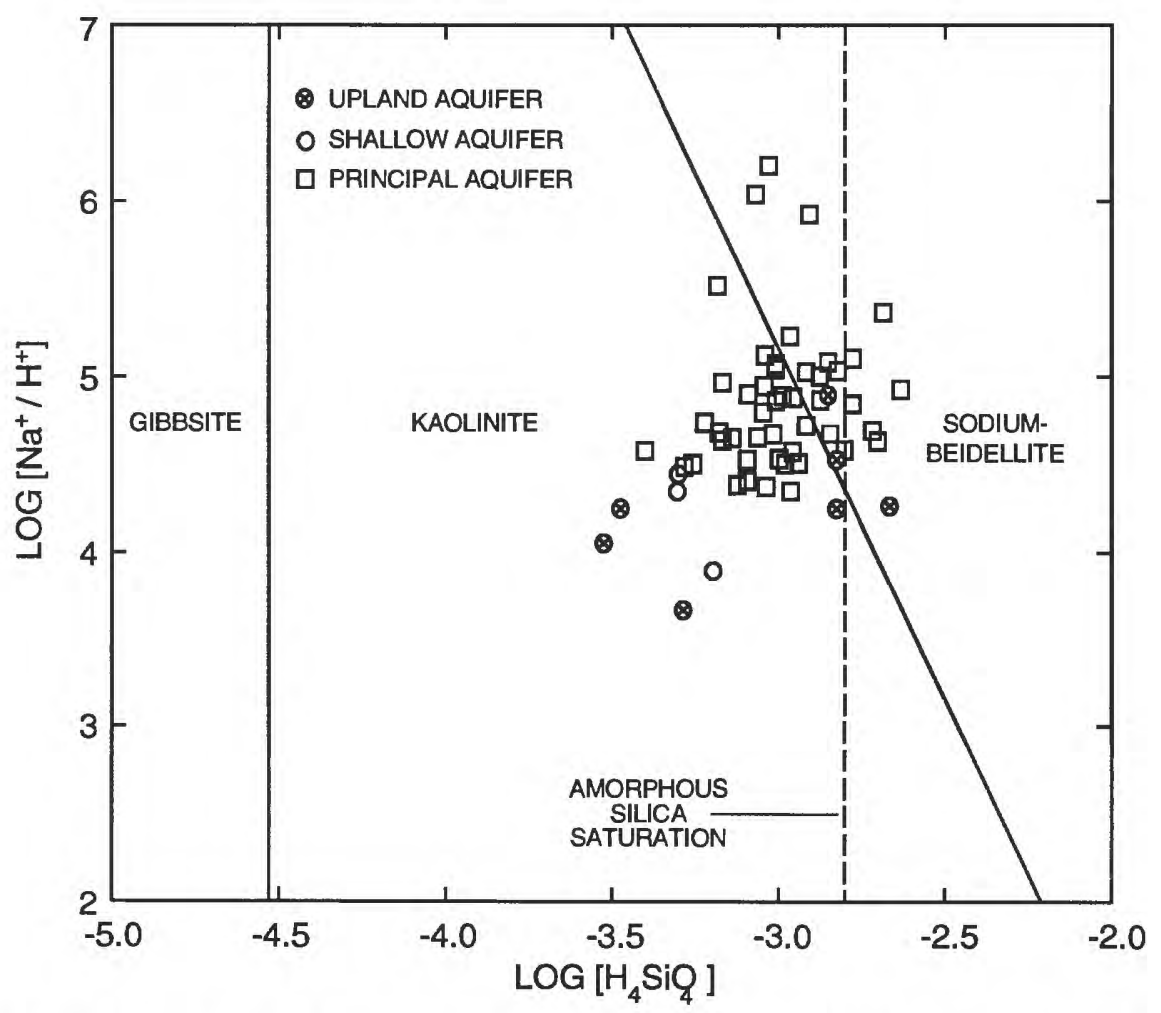

Figure 13. Relation between the activities of sodium and silica in ground-water samples from Dayton, Stagecoach, and Churchill Valleys. Phase boundaries are for $25^{\circ} \mathrm{C}$. 

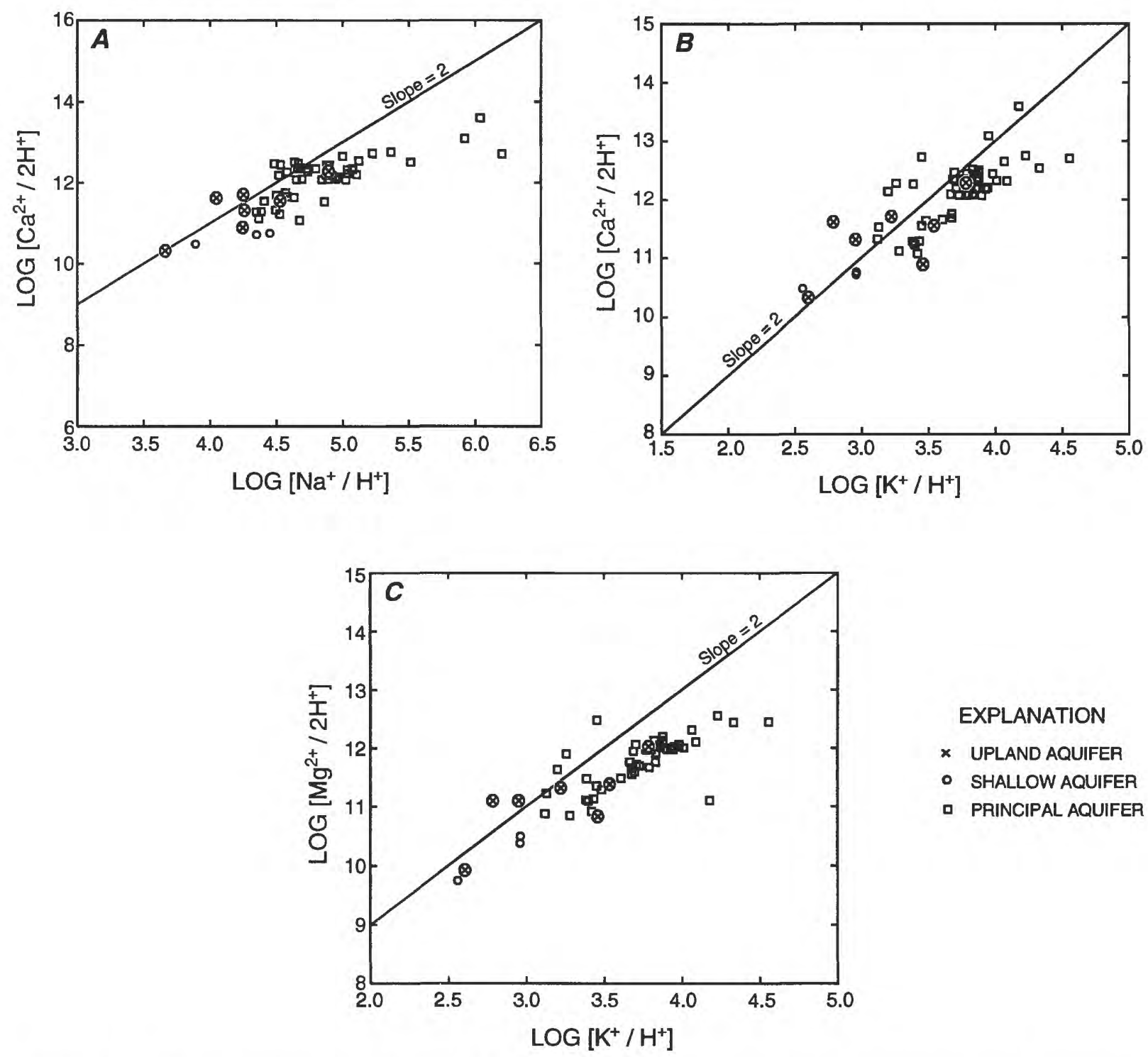

EXPLANATION

$\times$ UPLAND AQUIFER

- SHALLOW AQUIFER

- PRINCIPAL AQUIFER

Figure 14. Relation between the activities of $A$, calcium and sodium, $B$, calcium and potassium, and $C$, magnesium and potassium in ground-water samples from Dayton, Stagecoach, and Churchill Valleys.

(3) differences in the isotope composition of recharge or mixing waters; and (4) microbial processes, such as sulfate reduction.

Because gypsum and gypsite are present in the Mound House area of Dayton Valley (Moore, 1969), gypsum was used as the source of sulfate in the geochemical models. The sulfur isotopic composition of the gypsum deposits was not measured, but delta sulfur-34 $\left(\delta^{34} \mathrm{~S}\right)$ generally ranges from about 11 to 17 permil in Triassic and Jurassic marine evaporite deposits (Claypool and others, 1980, fig. 9). However, the $\delta^{34} \mathrm{~S}$ composition of the gypsite deposits may have a greater range than 11 to 17 permil because gypsite was deposited along ancient shore lines from erosion of gypsum deposits (Moore, 1969, p. 36). Thus, although gypsite deposits may be primarily produced by mechanical weathering, if gypsite was also chemically precipitated, sulfate in the gypsite may exhibit a wider range of isotopic composition. For example, Walker Lake, a remnant of Lake Lahontan approximately 50 miles south of the study area, contains sulfate in the pore water of lake-bottom sediments with an isotopic composition ranging from 4.5 to 30.9 permil (Rice and Tuttle, 1989, table 1). 
Table 5. Major-ion ratios for ground-water samples affected by recharge from the Carson River

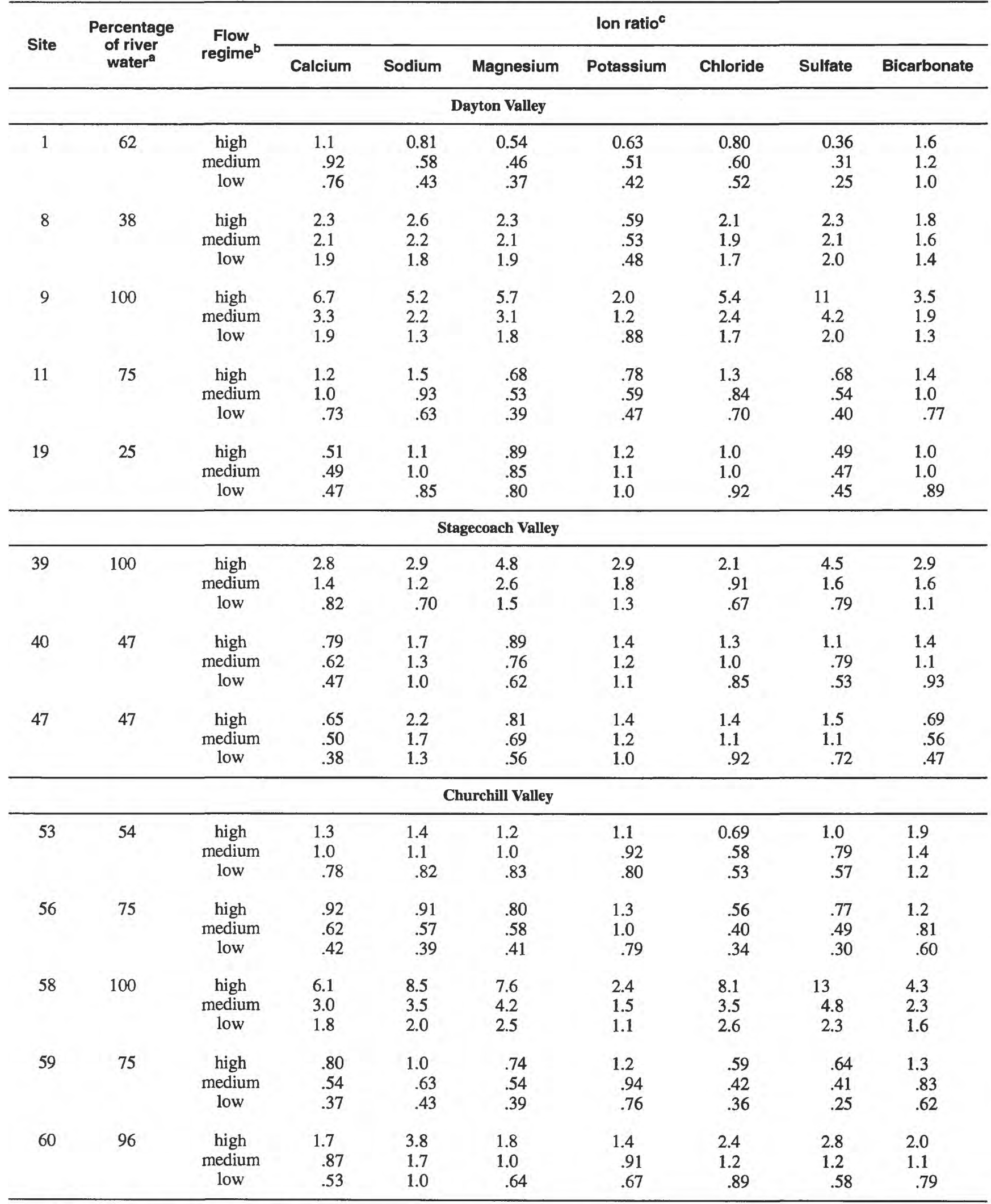

a Estimated on basis of deuterium values.

b High, 461 cubic feet per second $\left(\mathrm{ft}^{3} / \mathrm{s} ; 75\right.$ th percentile) and greater; medium, $>33.5-<461 \mathrm{ft}^{3} / \mathrm{s}\left(25\right.$ th to 75 th percentiles); low, $33.5 \mathrm{ft}^{3} / \mathrm{s}$ and less.

c For each ion, ratio equals concentration in ground water from sample site, divided by concentration of a mixture of (1) river water having median composition for stated flow regime and (2) ground water having median composition for principal aquifer in valley adjacent to sample site. 


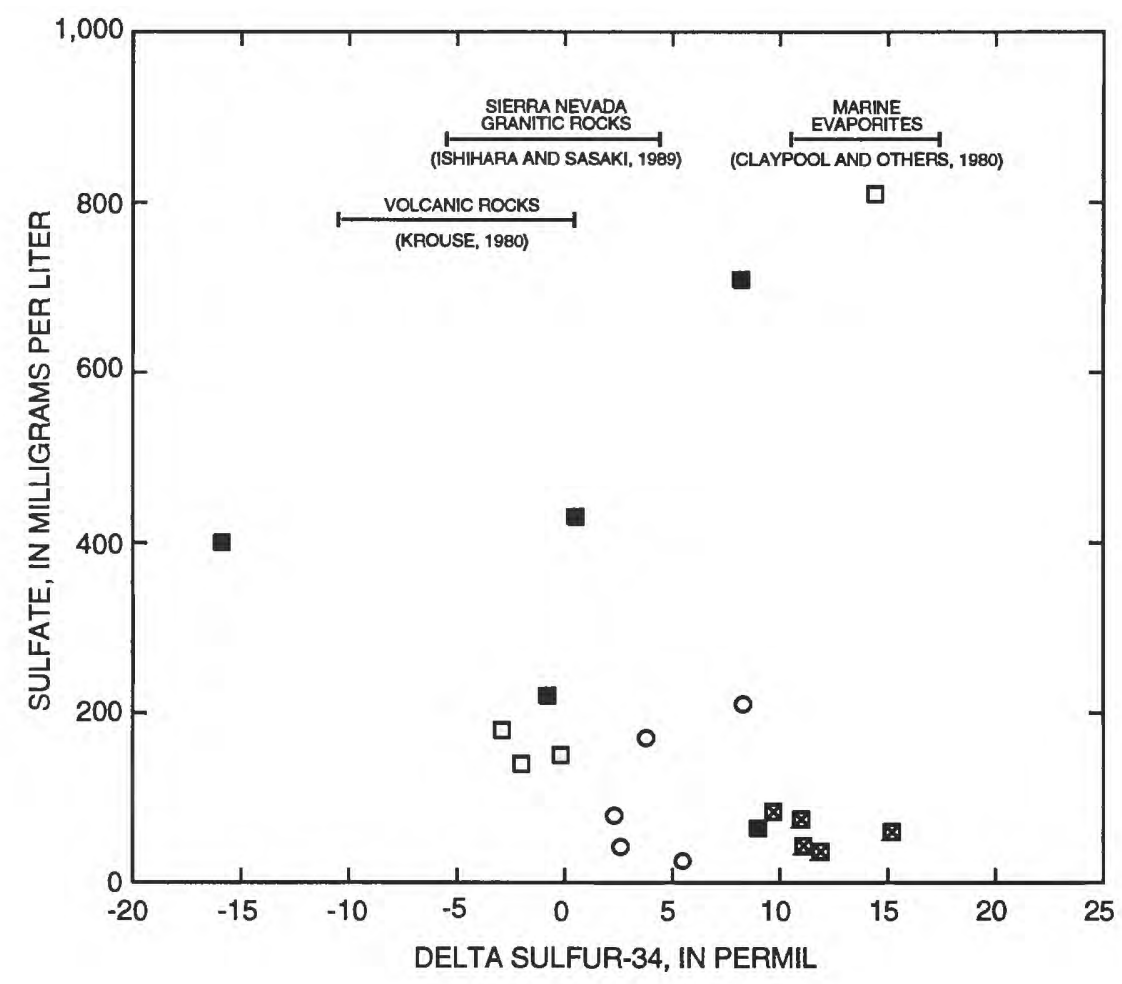

EXPLANATION

$\begin{array}{ll}\text { - } & \text { DAYTON VALLEY } \\ \text { - } & \text { STAGECOACH VALLEY } \\ \text { 口 } & \text { CHURCHILL VALLEY } \\ \text { a } & \text { AFFECTED BY CARSON RIVER WATER }\end{array}$

Figure 15. Relation between the concentration and isotope composition of dissolved sulfate in ground-water samples. Bars at top of figure represent ranges in delta sulfur-34 for different rock types.

The $\delta^{34} \mathrm{~S}$ of sulfate in ground-water samples in principal aquifers away from the Carson River ranges from -2.9 to 14.4 permil (with the exception of one sample, -15.9 permil), which indicates that sulfate is probably derived from a combination of sources and also may be subject to some microbial fractionation (figs. 15 and 16). Sulfate in most samples probably results from dissolution of gypsum in the sediments (with a probable range of $\delta^{34} \mathrm{~S}$ from about 11 to 17 permil, or possibly with a wider range) and pyrite in sediments derived from volcanic rocks $\left(\delta^{34} S\right.$ of sulfide minerals in volcanic rocks ranges from about -10 to 0 permil; Krouse, 1980, fig. 11-1). In addition, some of the sulfate in ground water can be derived from pyrite that has eroded from granitic rocks of the Sierra Nevada and has been deposited in the basin fill. The $\delta^{34} \mathrm{~S}$ of this sulfate should range from about -5 to 4 permil (Ishihara and Sasaki, 1989, fig. 3). One sample (at site 12) had an isotopic composition of -15.9 permil and a measured dissolved-oxygen concentration of less than $1.0 \mathrm{mg} / \mathrm{L}$, indicating some microbial sulfate reduction of this sample. A sample (from site 57) had a $\delta^{34} \mathrm{~S}$ of 14.4 permil and a sulfate concentration of $810 \mathrm{mg} / \mathrm{L}$, indicating the source of this sulfate was primarily dissolution of gypsum. The isotopic composition of dissolved sulfur probably is not affected by mineral precipitation because sulfate, sulfide, calcium, and iron concentrations are well below levels that could form common sulfur-bearing minerals, such as gypsum and pyrite. There is no apparent correlation between sulfate concentration and sulfur isotopic composition (fig. 15). 


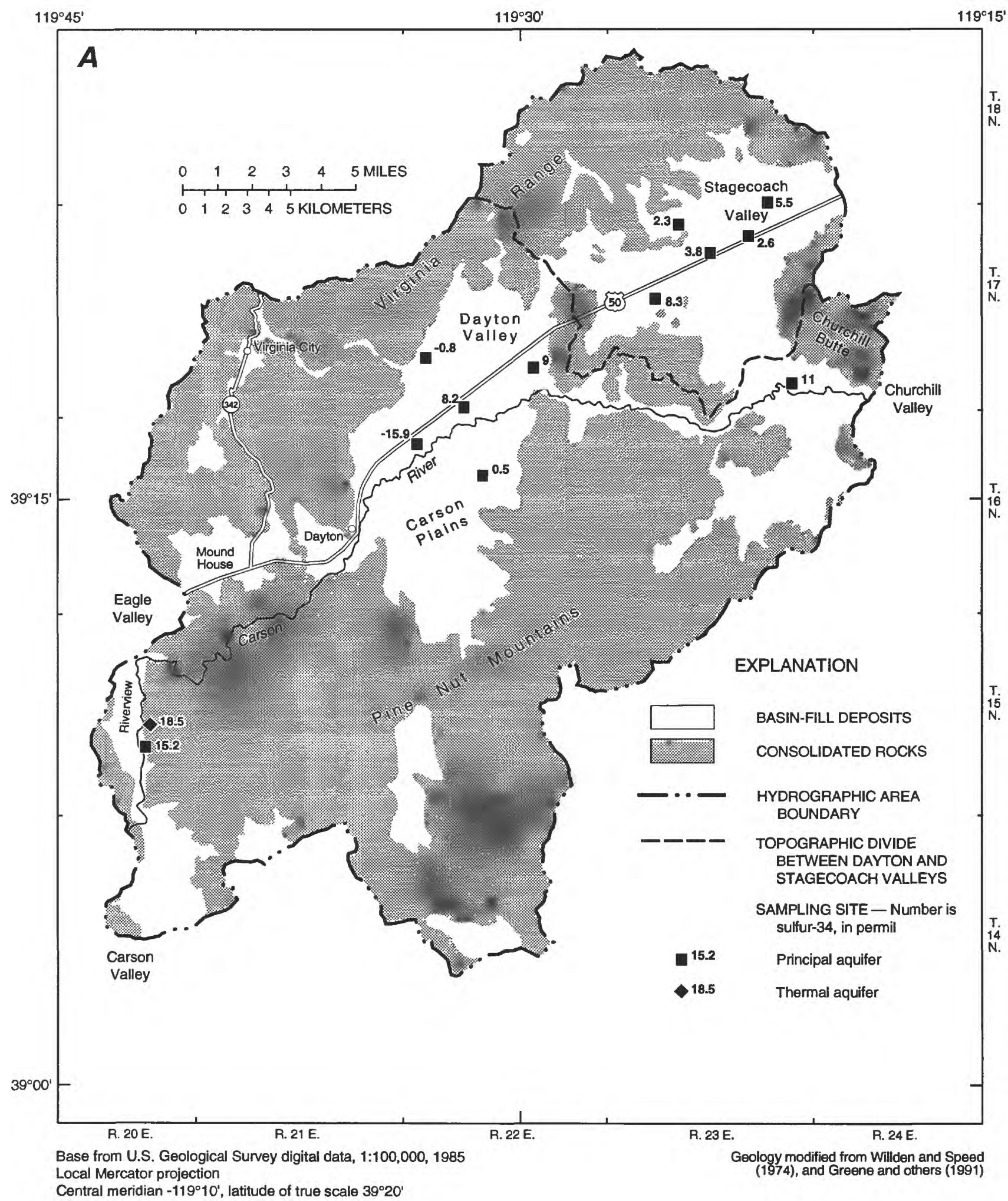

Figure 16. Sulfur-34 composition of ground-water samples from $A$, Dayton and Stagecoach Valleys, and $B$, Churchill Valley. 


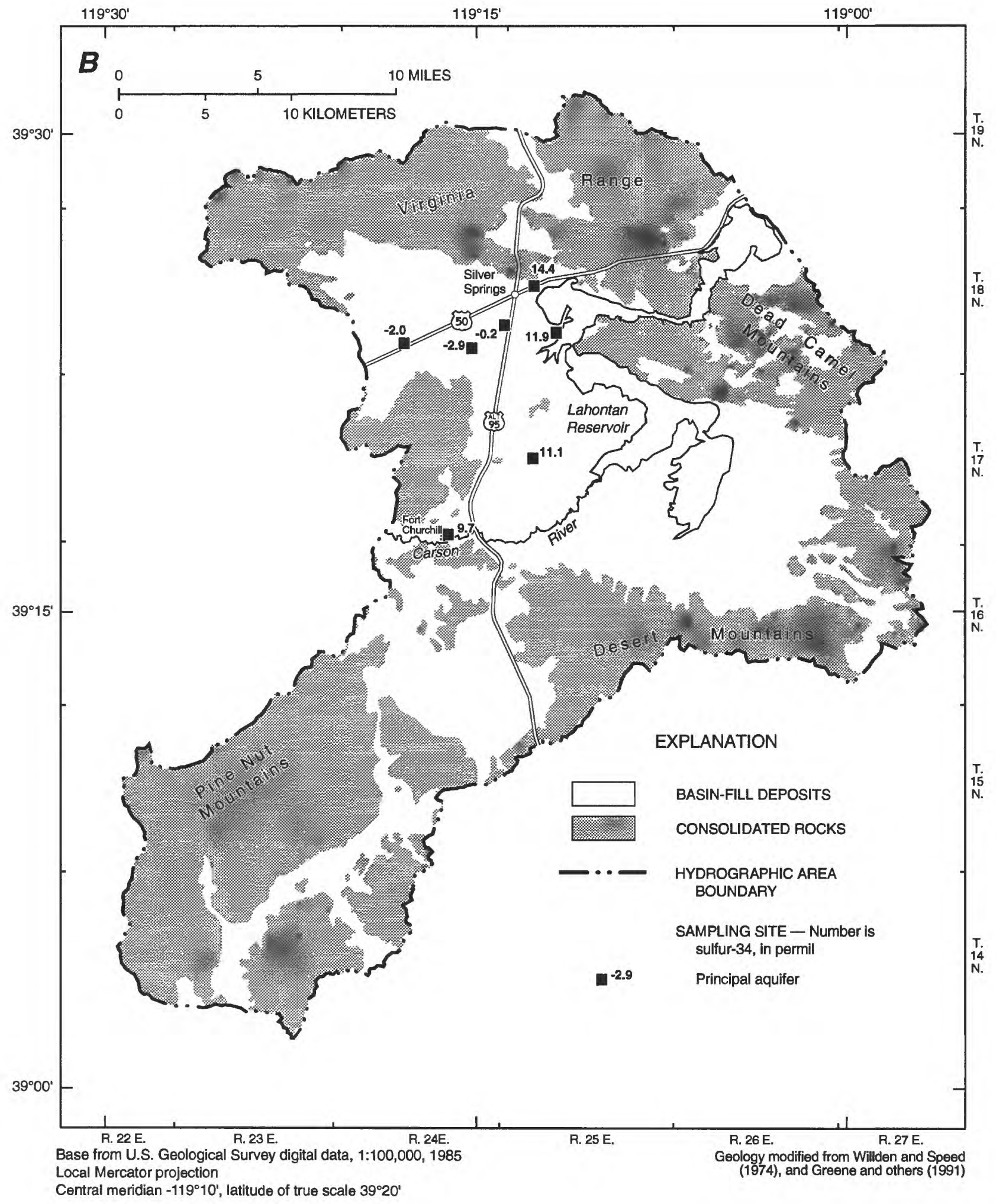

Figure 16.-Continued 
The isotopic composition of sulfate in ground water that is a mixture of Carson River and ground waters ranges from 9.7 to 15.2 permil (fig. 15). This isotopic composition indicates that the source of sulfate may be primarily dissolution of gypsum in the basin-fill sediments. The range in isotopic composition of sulfate dissolved in the water is similar to that expected for gypsum in the basin-fill sediments (11 to 17 permil). The sulfur-34 isotopic composition of sulfate dissolved in the ground water indicates that the dissolution of gypsum (used for the source of sulfur in the geochemical models) is not the only source of sulfate in most samples. Sulfur from dissolution of sulfide minerals (mainly pyrite) derived from volcanic and granitic rocks probably also adds sulfate to the water (see section titled "Modeling of Geochemical Reactions"). In addition, sulfate reduction may be affecting the isotopic composition of sulfate in some ground water.

The carbon-13 composition $\left(\delta^{13} \mathrm{C}\right)$ of inorganic carbon dissolved in ground water depends on the isotopic composition of the different sources of carbon and the fractionation between carbon phases and dissolved carbon. In the study area, the absence of carbon isotope data for samples in recharge areas precluded the use of $\delta^{13} \mathrm{C}$ to evaluate the sources of carbon dissolved in the upland aquifer water, and also in subsequent reactions involving carbon as the ground water moves from recharge areas to the principal aquifers. However, the $\delta^{13} \mathrm{C}$ of water in the principal aquifers can be used to infer the sources of carbon dissolved in water in the upland aquifers, which is important for age dating of the ground water.

Initial carbon concentrations in ground water are generally derived from equilibration of water with carbon dioxide as it passes through the root zone in recharge areas. Some of this carbon dioxide can be derived from atmospheric carbon dioxide, but most of the carbon dioxide in the root zone is from plant-root respiration and oxidation of organic matter. Atmospheric carbon dioxide has a $\delta^{13} \mathrm{C}$ of about -8.7 permil in southern Nevada (Thorstenson and others, 1990, table 2) and probably has a similar composition in northern Nevada. The $\delta^{13} \mathrm{C}$ of carbon dioxide respired by plants depends primarily on the metabolic pathway of the plants. Carbon dioxide released by plants using a $_{3}$ metabolic pathway, such as pine and fir trees, has a $\delta 13 C$ of about -27 permil (Deines, 1980). Vegetation utilizing the $\mathrm{C}_{4}$ metabolic pathway, such as Atriplex (salt brush), produces carbon dioxide with a composition of about -13 permil (Deines, 1980; and Cerling,
1984). Organic matter in the root zone is primarily from dead plant material; the $\delta^{13} \mathrm{C}$ of this matter depends on the plant type. Thus, oxidation of organic matter produces carbon dioxide of the same $\delta^{13} \mathrm{C}$ as root respiration (Deines, 1980). Mountainous recharge areas surrounding the study area contain both $\mathrm{C}_{3}$ and $\mathrm{C}_{4}$ vegetation; thus, a $\delta^{13} \mathrm{C}$ of root-zone carbon dioxide of about -20 permil could be expected in these recharge areas.

The $\delta^{13} \mathrm{C}$ of ground water in principal aquifers in the study area ranges from -15.1 to -8.0 permil (figs. 17 and 18). Assuming an average temperature of $10^{\circ} \mathrm{C}$ and a $\mathrm{pH}$ range of 7.0 to 8.0 , the fractionation between carbon dioxide and dissolved carbonate is -9 to -7 permil (Wigley and others, 1978 , fig. 2). Using a fractionation of -8 permil for the ground-water samples indicates that root-zone carbon dioxide would have a $\delta^{13} \mathrm{C}$ of -23.1 to -16.0 permil, if the main source of dissolved carbon is plant-respired carbon dioxide. Thus, the primary source of carbon dissolved in ground water in the principal aquifers could be equilibration of root-zone carbon dioxide with ground water in the recharge areas. A study by Welch (1994) in adjacent Carson and Eagle Valleys also concluded that dissolved carbon is most likely from equilibration with soil-zone carbon dioxide.

The presence of limestone and dolomite in metamorphic rocks in the mountains (Moore, 1969) and calcite in the basin-fill deposits indicates that the dissolution of calcite and dolomite could be another source of dissolved carbon in ground water in the study area. Some calcite and dolomite in upland aquifers in the mountainous recharge areas could dissolve because most samples from the upland aquifers are undersaturated with calcite and dolomite. The $\delta^{13} \mathrm{C}$ of these carbonate rocks has not been determined; but on the basis of their marine origin, it probably is about 0 permil (Mazor, 1991, p. 171). If the $\delta^{13} \mathrm{C}$ of ground water in principal aquifers is little changed from that of recharge water in the upland aquifers, carbonate minerals could have dissolved in the recharge areas. If the $\delta^{13} \mathrm{C}$ of carbon dioxide is relatively uniform in the root zone in the recharge areas throughout the study area, the ground water with the heavier (more positive) $\delta^{13} \mathrm{C}$ could have obtained some carbon from dissolution of marine carbonate minerals. Thermodynamic and mass-balance calculations, and the optical observation that calcite forms as surface coatings on mineral grains in basin-fill sediments, indicate that calcite could precipitate from 


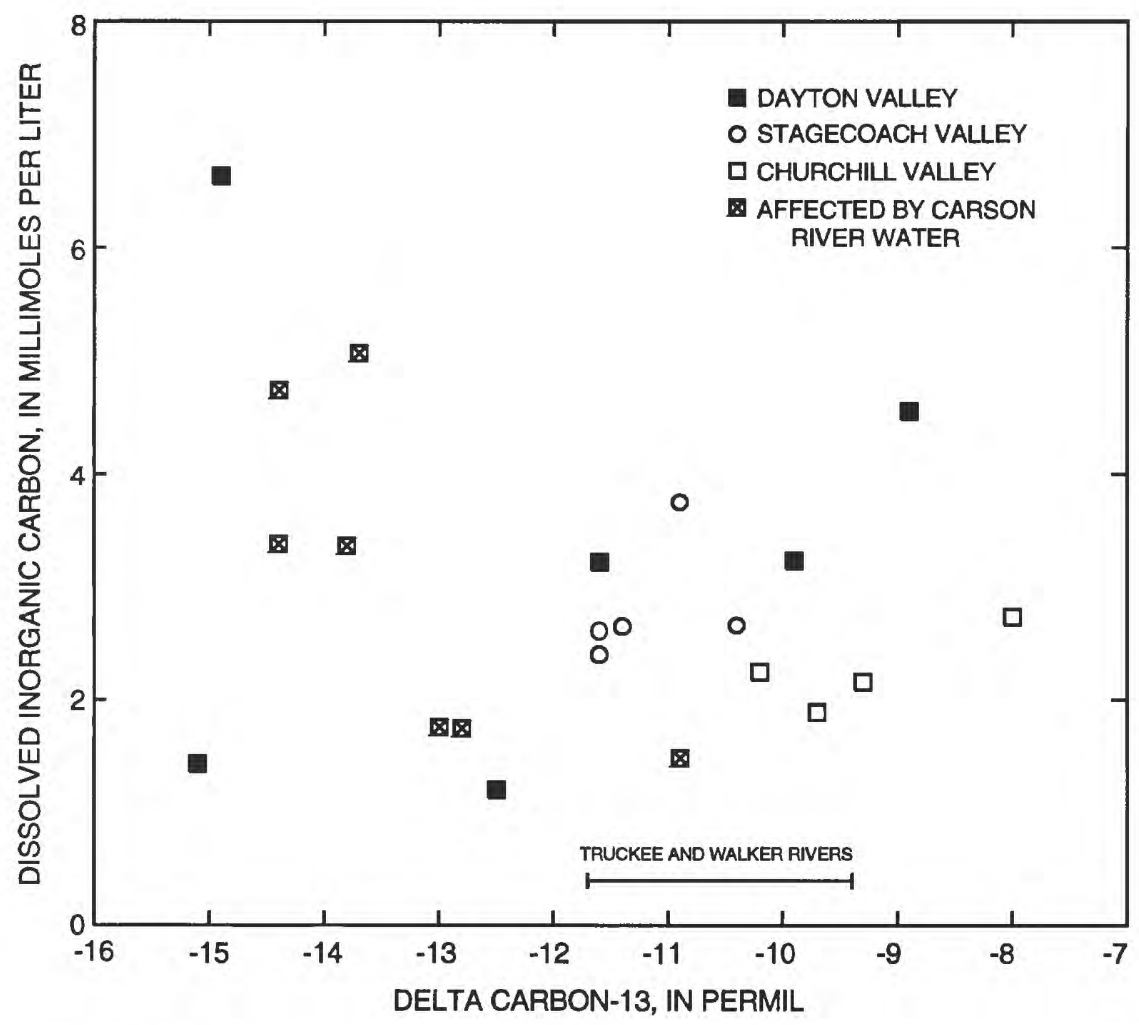

Figure 17. Relation between the carbon-13 content of the dissolved inorganic carbon and the concentration of the dissolved inorganic carbon in ground-water samples. Bar at the bottom of the figure represents the range in delta carbon-13 for the Truckee and Walker Rivers.

ground water in the principal and shallow aquifers and probably is not a significant source of carbon in this part of the study area.

Another possible source of dissolved carbon is sedimentary organic matter in basin-fill deposits, particularly along the Carson River. Sedimentary organic matter may contribute a small amount of carbon to the total dissolved inorganic carbon content, but only a small amount of organic matter could be oxidized because of the presence of dissolved oxygen in excess of $1 \mathrm{mg} / \mathrm{L}$ in most ground-water samples from the principal aquifer (fig. 19). This absence of oxidation of significant amounts of organic carbon assumes that ground water in the principal aquifers is closed from contact with atmospheric circulation. Carbon derived from oxidation of organic matter would have a $\delta^{13} \mathrm{C}$ similar to the plant-respired soil-zone carbon dioxide (Deines, 1980) and thus, would have little affect on the $\delta^{13} \mathrm{C}$ of the ground water.

The $\delta^{13} \mathrm{C}$ of ground water that contains a significant proportion of Carson River water ranges from -14.4 to -10.9 permil (fig. 17). There are no carbon-13 data for the Carson River water, but data are available for the Truckee and Walker Rivers in adjacent drainage basins to the north and south. The $\delta^{13} \mathrm{C}$ of the Truckee River (9 samples at Nixon) ranges from -11.2 to -9.6 permil with an average of -10.6 permil and the Walker River (15 samples at Wabuska) ranges from -11.7 to -9.4 with an average of -10.1 permil (L.V. Benson, U.S. Geological Survey, written commun., 1991). Ground-water samples affected by river water were about 1 to 3 permil lighter (with the exception of 1 sample) than values for the Truckee and Walker Rivers (fig. 17). These lighter compositions may have been caused by a lighter $\delta^{13} \mathrm{C}$ of dissolved carbon in the Carson River than in the Truckee and Walker Rivers; however, there is no apparent reason for this river water to be isotopically different from the two adjacent rivers. A more likely source is the equilibration of river water (that has infiltrated the principal aquifers) with soil carbon dioxide, or dissolution of organic matter in sediments adjacent to the river (this carbon should have a $\delta^{13} \mathrm{C}$ that ranges from about -23 to -16 permil). The $\delta^{13} \mathrm{C}$ of the river-affected samples can not be produced by mixing river water with ground-water in the adjacent principal aquifer, because $\delta^{13} \mathrm{C}$ in samples from the nearby principal aquifer are generally heavier than in the river-affected samples (figs. 17 and 18). This 


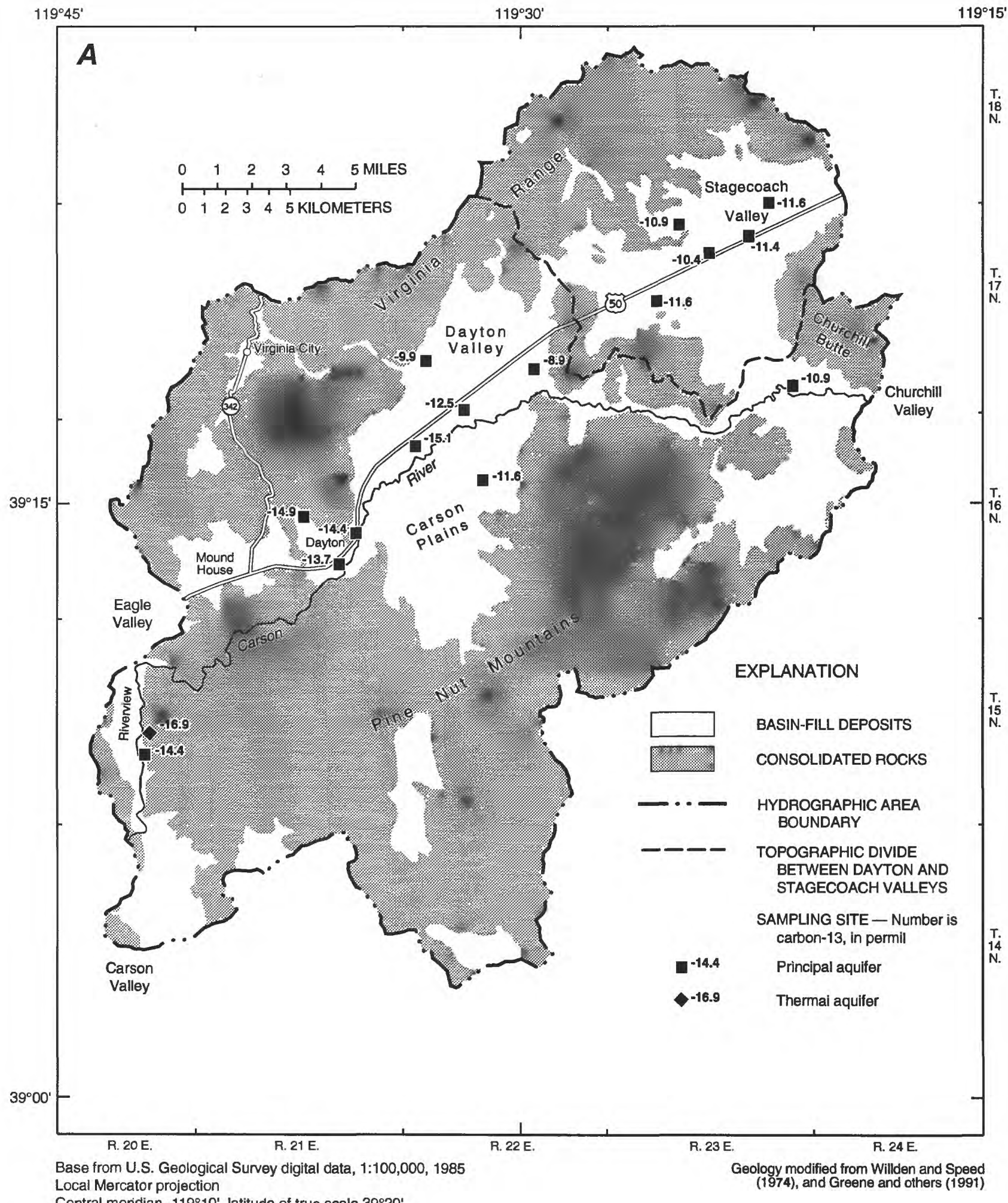

Central meridian $-119^{\circ} 10^{\prime}$, latitude of true scale $39^{\circ} 20^{\prime \prime}$

Figure 18. Carbon-13 composition of dissolved inorganic carbon in ground-water samples from A, Dayton and Stagecoach Valleys, and $B$, Churchill Valley. 


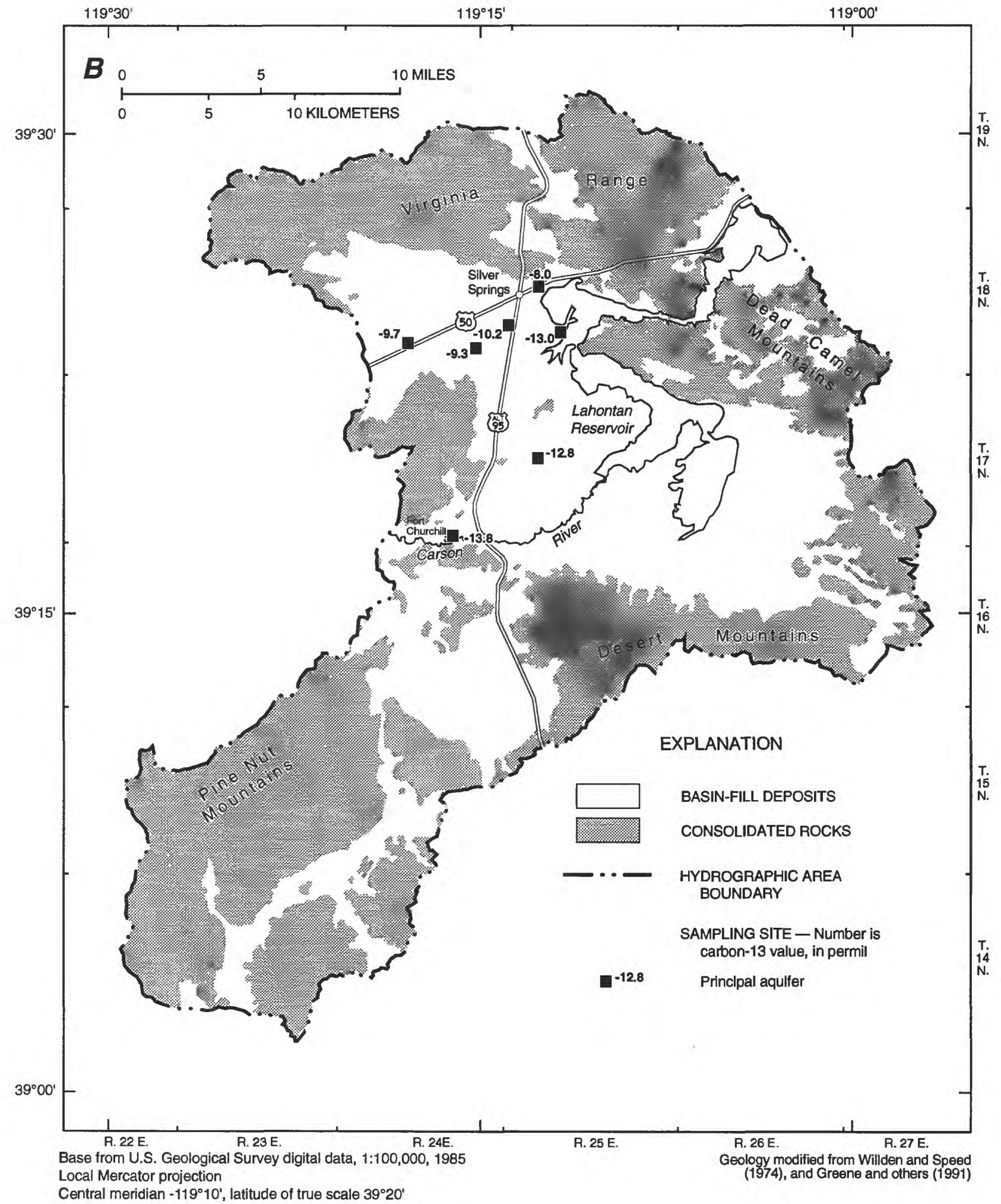

Figure 18.-Continued 


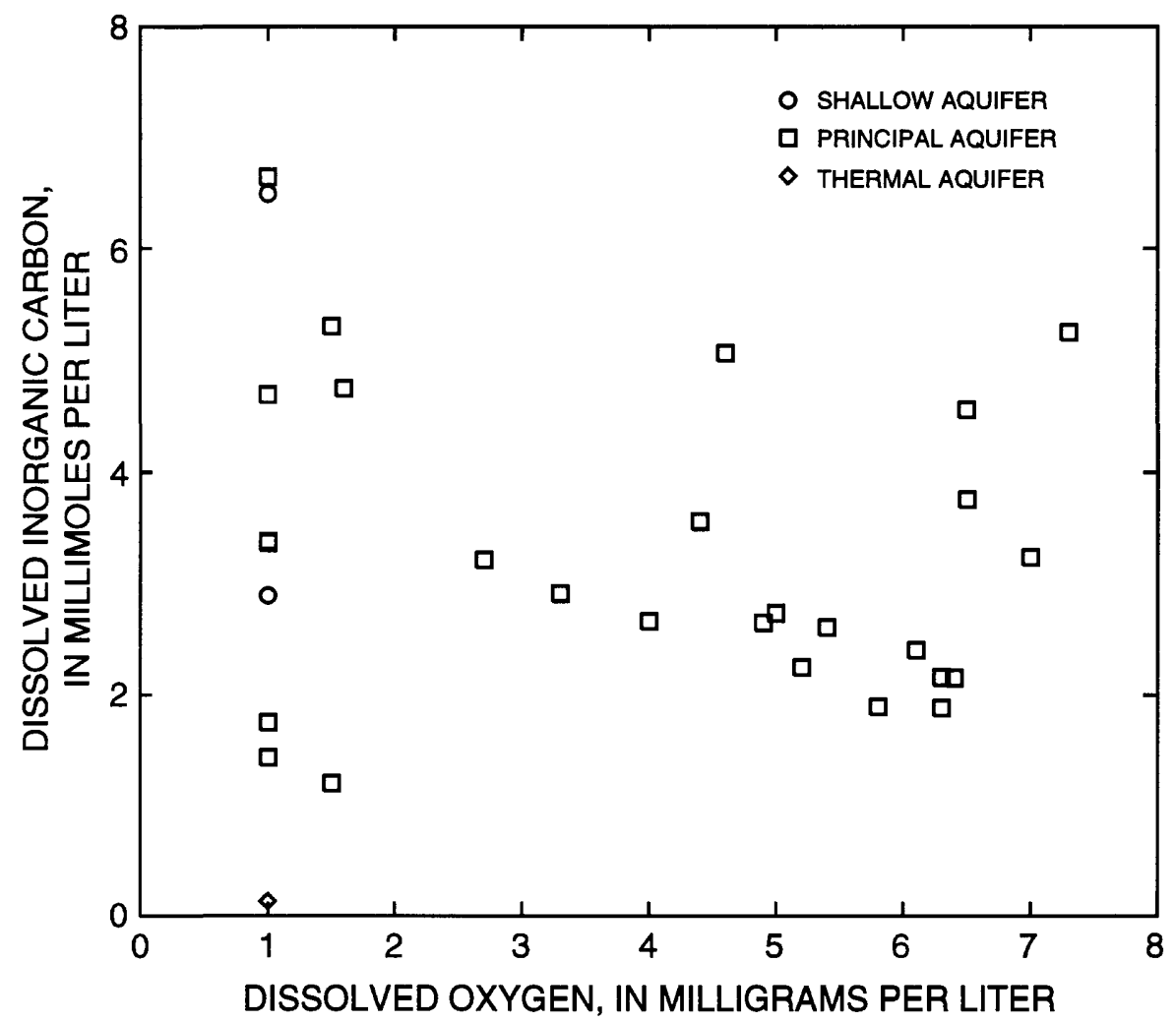

Figure 19. Relation between dissolved inorganic carbon and dissolved oxygen for ground-water samples from Dayton, Stagecoach, and Churchill Valleys.

indicates reactions involving carbon take place after mixing. The addition of carbon to the mixed water from soil-zone carbon dioxide or organic matter, with a lighter $\delta^{13} \mathrm{C}$, fits the geochemical model in which carbon is added to the mixed waters (see section titled "Modeling of Geochemical Reactions" and table 5).

\section{Age Dating of Ground Water by Using Carbon Isotopes}

The age of ground water along a flow path can be determined by using carbon isotopes, carbon mass transfers calculated using geochemical models, and fractionation of carbon-13 during geochemical processes. There are no carbon isotope data for samples in the recharge areas, thus carbon-14 ground-water ages cannot be calculated using the geochemical models for ground-water flow from recharge areas to the principal aquifers. However, ground-water ages can be calculated if the carbon isotopic composition of ground water in the recharge areas can be estimated. A sample from the principal aquifers analyzed for carbon isotopes (site 17) had a tritium concentration of $6.9 \mathrm{pCi} / \mathrm{L}$ (table 6), indicating this sample contained water recharged between 38 and 57 years ago, assuming no mixing. If this water contained carbon-13 and carbon14 compositions typical of water that recharged the principal aquifers during the past, its carbon- 14 content of 83.6 percent modern carbon (PMC) and carbon-13 content of -11.6 permil could represent the initial carbon-isotopic content of water in these aquifers.

Interpretation of carbon-13 data for ground-water samples from the principal aquifers indicates that dissolved carbon may be primarily from equilibration with carbon dioxide in the root-zone in the recharge areas, so a ground-water age can be estimated by assuming the difference in carbon-14 measured in principal aquifer samples, as compared to $83.6 \mathrm{PMC}$, is a result of radioactive decay. This is termed an "opensystem" model, in which the only contribution of carbon to the ground water is by equilibration of carbon dioxide in the root-zone with the water. The ages calculated by using this model are given in table 6 . These ages may overestimate the actual age of the ground water because the model assumes no dissolution of carbonate minerals. 
Table 6. Estimated age of ground-water samples from principal aquifers of the study area

[Abbreviations: pCi/L, picocuries per liter; PMC, percent modern carbon; --, not determined; <, less than; modern, recharge since about 1950]

\begin{tabular}{|c|c|c|c|c|c|}
\hline \multirow{2}{*}{ Site } & \multirow{2}{*}{$\begin{array}{l}\text { Tritium } \\
\text { (pCl/L) }\end{array}$} & \multirow{2}{*}{$\begin{array}{c}\text { Carbon-13 } \\
\text { (permll) }\end{array}$} & \multirow{2}{*}{$\begin{array}{c}\text { Carbon-14 } \\
\text { (PMC) }\end{array}$} & \multicolumn{2}{|c|}{$\begin{array}{c}\text { Estimated age } \\
\text { (years) }\end{array}$} \\
\hline & & & & $\begin{array}{l}\text { Open } \\
\text { system }\end{array}$ & $\begin{array}{l}\text { Ciosed } \\
\text { system }\end{array}$ \\
\hline \multicolumn{6}{|c|}{ Dayton Valley } \\
\hline 13 & $<0.3$ & -9.9 & 90.8 & modern & modern \\
\hline 17 & 6.9 & -11.6 & 83.6 & modern & modern \\
\hline 18 & $<0.3$ & -8.9 & 25.4 & 9,800 & 4,800 \\
\hline \multicolumn{6}{|c|}{ Stagecoach Valley } \\
\hline 25 & -- & -11.6 & 72.1 & 1,200 & modern \\
\hline 30 & $<0.3$ & -10.9 & 67.6 & 1,800 & modern \\
\hline 34 & -- & -10.4 & 46.1 & 4,900 & 1,200 \\
\hline 41 & $<.3$ & -11.4 & 37.3 & 6,700 & 3,700 \\
\hline 44 & -- & -11.6 & 3.3 & 27,000 & 24,000 \\
\hline \multicolumn{6}{|c|}{ Churchill Valley } \\
\hline 49 & $<0.3$ & -9.7 & 34.9 & 7,200 & 2,900 \\
\hline 54 & .3 & -9.3 & 22.4 & 11,000 & 6,200 \\
\hline 55 & -- & -10.2 & 27.9 & 9,100 & 5,200 \\
\hline 57 & -- & -8.0 & 10.3 & 17,000 & 11,000 \\
\hline \multicolumn{6}{|c|}{ Samples affected by Carson River water } \\
\hline 1 & 3.4 & -14.4 & 91.5 & modern & modern \\
\hline 9 & 27 & -14.4 & 109.2 & modern & modern \\
\hline 47 & 3.3 & -10.9 & 52.3 & 3,900 & modern \\
\hline 53 & -- & -13.8 & 100.7 & modern & modern \\
\hline 56 & $<.3$ & -12.8 & 91.7 & modern & modern \\
\hline 59 & $<.3$ & -13.0 & 78.8 & 500 & modern \\
\hline
\end{tabular}


Carbon-13 data indicate that some dissolution of carbonate minerals in the recharge areas may have occurred (see section titled "Modeling of Geochemical Reactions"). In general, as carbon-14 decreases, carbon-13 increases (fig. 20). If carbon-13 has remained relatively constant in the recharge area, this relation indicates that some of the dissolved inorganic carbon is from dissolution of marine carbonate minerals. The marine carbonate rocks in the study area should have a $\delta^{13} \mathrm{C}$ of about 0 permil and a carbon- 14 composition of 0 PMC, thus dissolution of these minerals would result in an increase in $\delta^{13} \mathrm{C}$ and a decrease in carbon-14. Ground-water age can be estimated using this "closedsystem" model in which the water becomes isolated from root-zone carbon dioxide and dissolves carbonate minerals, if the $\delta^{13} \mathrm{C}$ of the calcite and carbon dioxide and the carbon-14 composition of the final water can be measured or estimated (Ingerson and Pearson, 1964). The $\delta^{13} \mathrm{C}$ of carbon dioxide was estimated using the $\delta^{13} \mathrm{C}$ at site 17 ( -11.6 permil). Assuming a fractionation factor of -8.0 permil for the fractionation of carbon- 13 between carbon dioxide and carbon dissolved in the ground water (see section titled "Modeling of
Geochemical Reactions"), the carbon dioxide would have a $\delta^{13} \mathrm{C}$ of -19.6 permil. This value is consistent with the mixed $\mathrm{C}_{3}$ and $\mathrm{C}_{4}$ type plants in the recharge areas. Carbon-14 ages calculated using the Ingerson and Pearson (1964) closed-system model are in table 6.

Ground-water ages estimated for samples from the principal aquifers generally are less than 6,000 years, but reach a maximum of 24,000 years for the closed-system model. Ages estimated from the closedsystem model were used for interpretation because generally as carbon-13 increases, carbon-14 decreases, indicating a system that has become isolated from rootzone gas. Estimated ages for the three ground-water samples in Dayton Valley indicate that two of the samples are modern (recharged since about 1950) and one is 4,800 years old. The 4,800-year estimate was for a sample taken from easternmost Dayton Valley and may represent ground water that originated in recharge areas to the west. The two modern waters are samples from wells in alluvial fans adjacent to the Virginia and Pine Nut Mountain recharge areas. Four of five samples taken in Stagecoach Valley were estimated to range in age from modern to 3,700 years; the fifth sample had

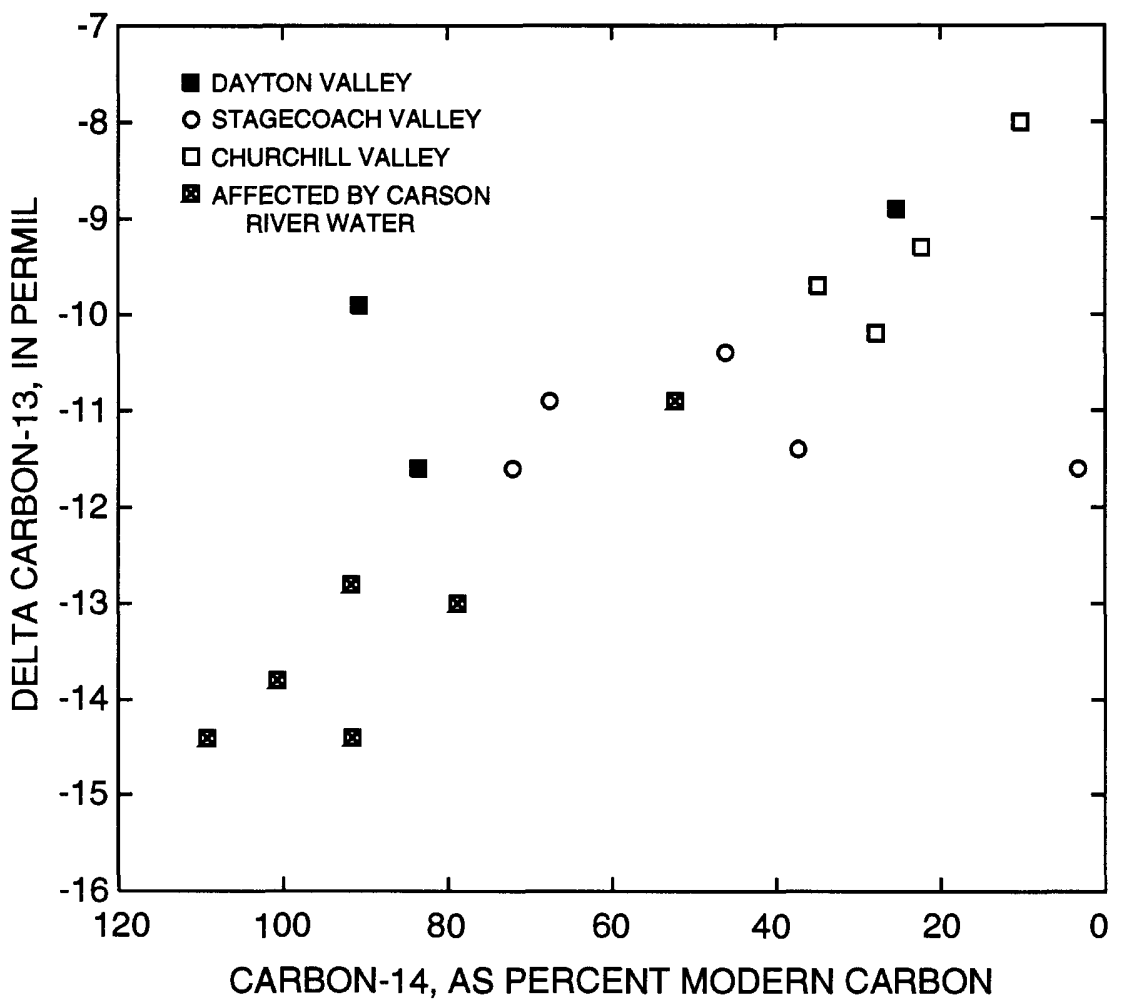

Figure 20. Relation between the carbon-13 composition and carbon-14 activity of dissolved inorganic carbon for ground-waters. 


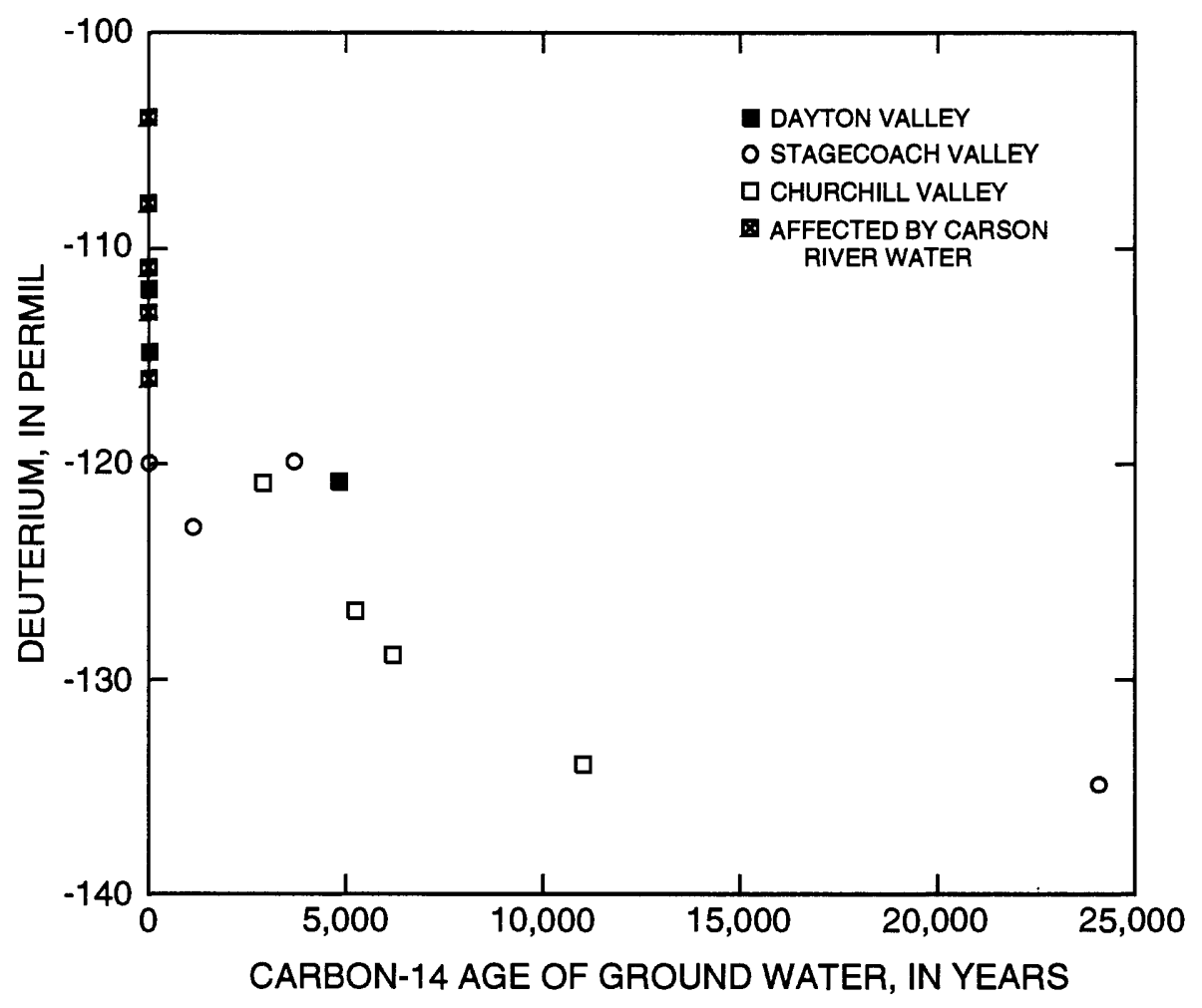

Figure 21. Relation between deuterium and estimated carbon-14 ages for groundwater samples.

an estimated age of 24,000 years. The age of the water increases from west to east across the basin. However, the 24,000- and 3,700-year-old waters are only about 1 mile apart, making the great age discrepancy difficult to explain. The age difference is apparently not caused by sampling different parts of the aquifer; the wells have about the same land-surface altitude and the well with the younger water is about $40-\mathrm{ft}$ deeper than the well with the older water. The old age of the water may be explained by its location on an alluvial fan adjacent to a part of the mountain that yields very little recharge today; thus, the water may have traveled a long distance from its recharge source or may have been recharged a long time ago in the adjacent mountains during a wetter climate. The well with the oldest water in adjacent Churchill Valley is similarly located near these mountains. Four samples in Churchill Valley were estimated, based on the closed-system model, to range in age from 2,900 to 11,000 years (table 6). These older ages indicate that little or no recharge may be occurring today in the adjacent Virginia Range. All ground-water samples affected by
Carson River water are estimated to be modern (table 6). The modern ages agree with the tritium data in that three of the samples contain 3.3 to $27 \mathrm{pCi} / \mathrm{L}$ of tritium. A general decrease in deuterium corresponds to an increase in carbon-14 age (fig. 21). This relation can result from (1) a cooler past climate, (2) a change in recharge areas for the principal aquifers with time, or (3) a change in storm tracks with time.

\section{Minor Inorganic Constituents}

Analytical results for 25 minor constituents in ground-water are summarized in table 7. Among these constituents, only selenium exceeded Nevada State MCL's at a single site. Nevada State SMCL's were exceeded in 1 sample for fluoride, 7 samples for iron, and 19 samples for manganese. Iron and manganese also exceeded Nevada State SPS's in 3 and 13 samples, respectively (table 7 and figs. 22 and 23).

Concentrations of arsenic, boron, fluoride, iron, manganese, nitrogen, and selenium in ground-water samples vary widely in the study area. Clusters of wells with high concentrations of these constituents 


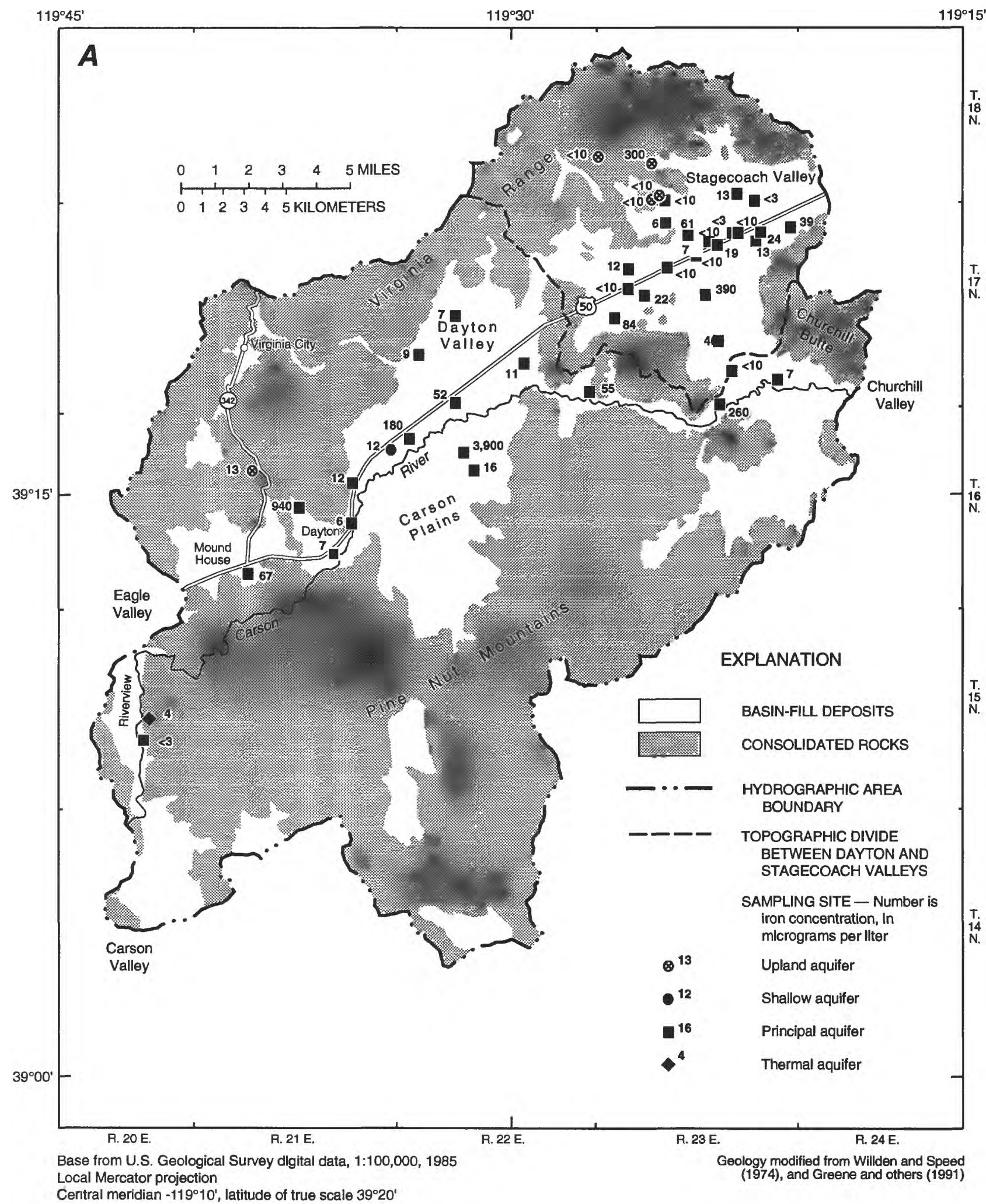

Figure 22. Concentration of iron in ground-water samples from $A$, Dayton and Stagecoach Valleys, and $B$, Churchill Valley 


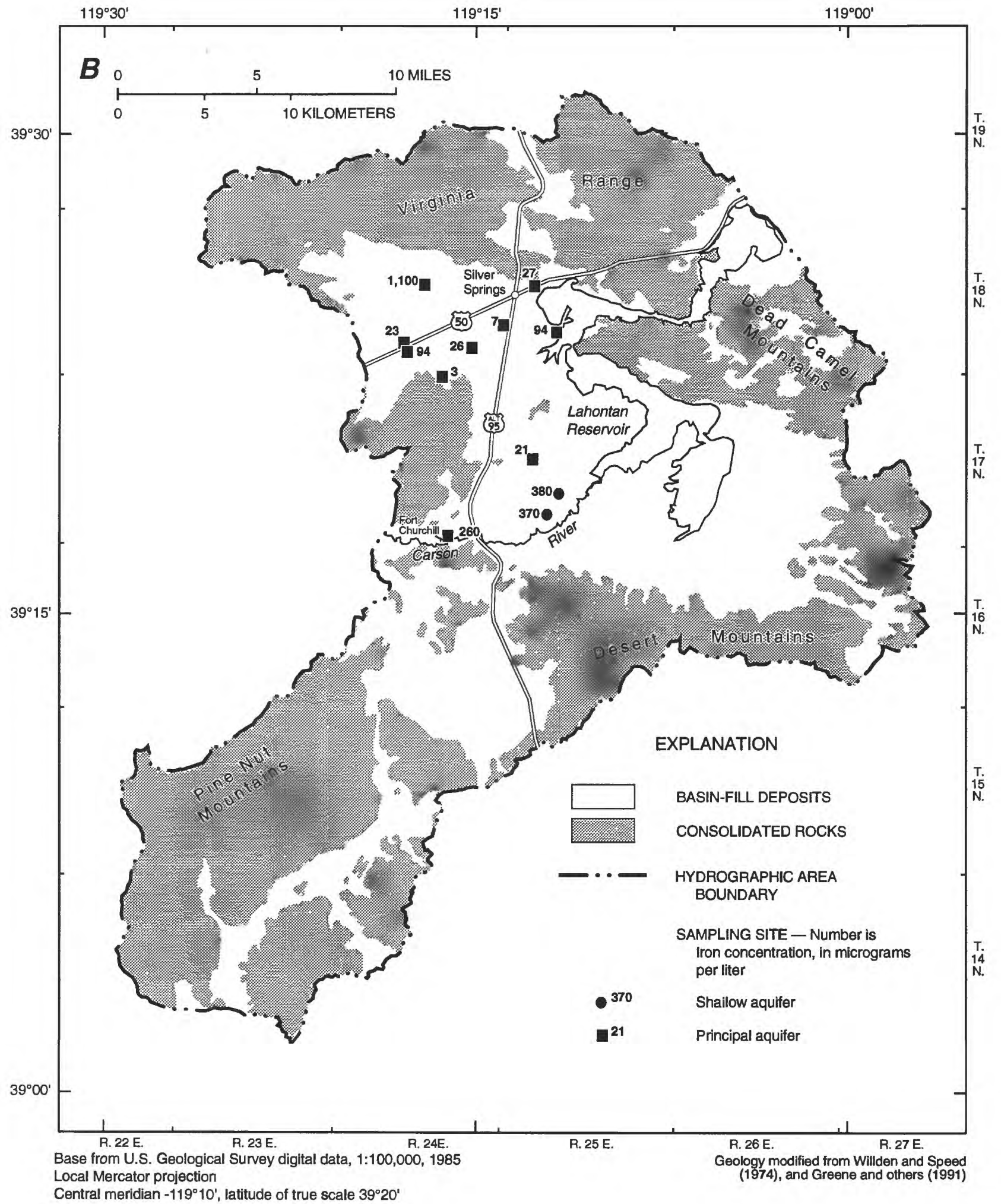

Figure 22.-Continued 


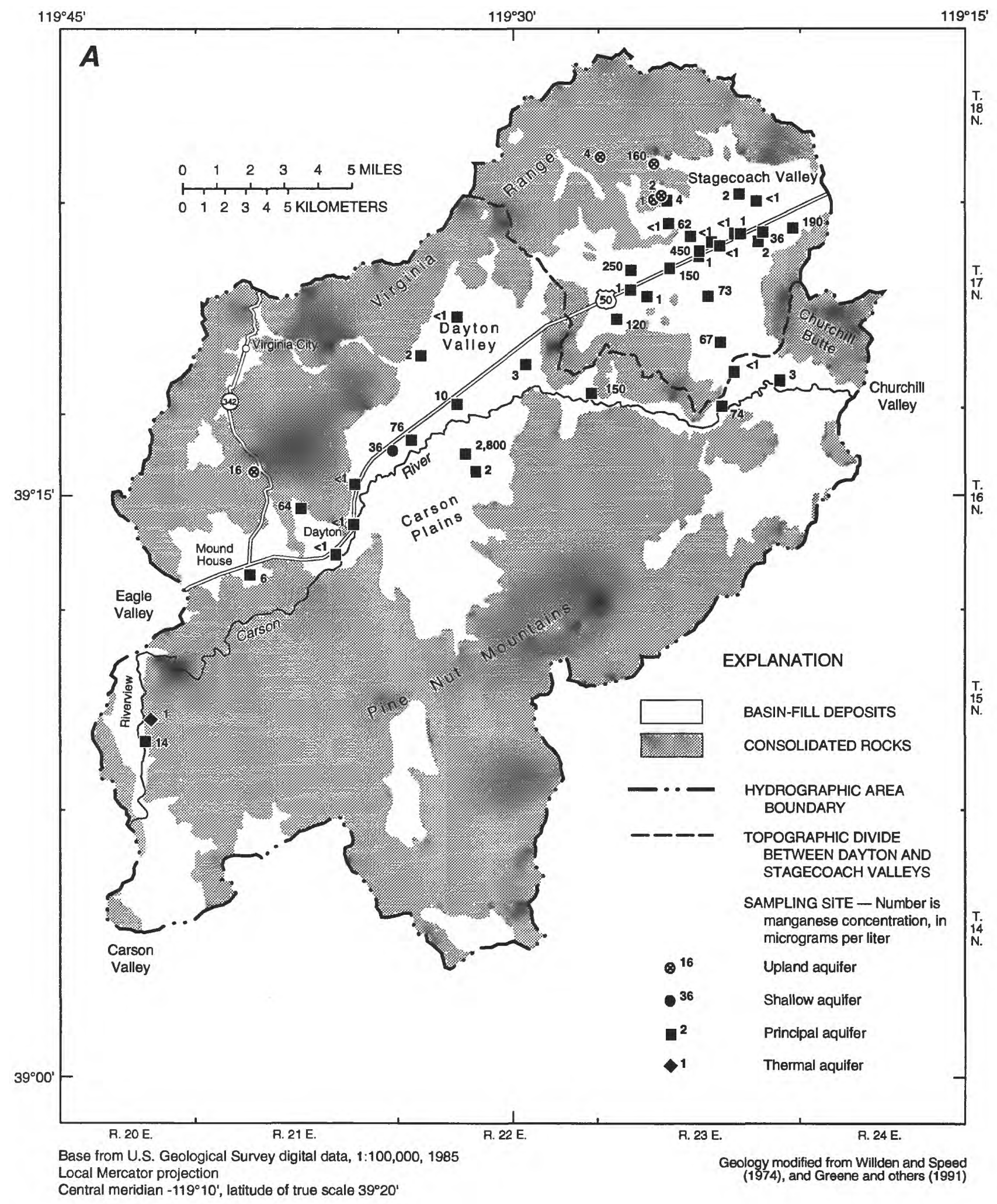

Figure 23. Concentration of manganese in ground-water samples from $A$, Dayton and Stagecoach Valleys, and $B$, Churchill Valley. 


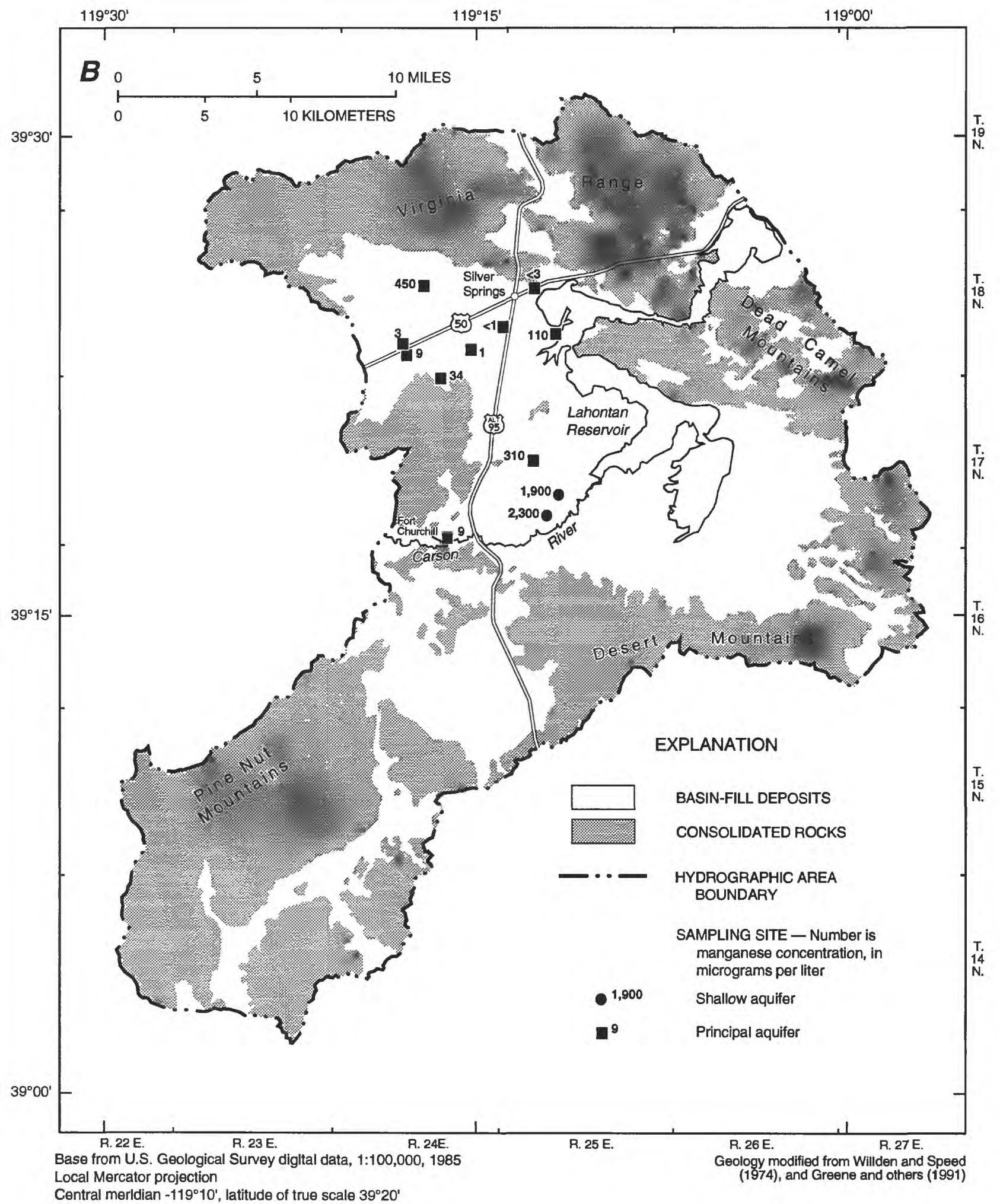

Figure 23.-Continued 


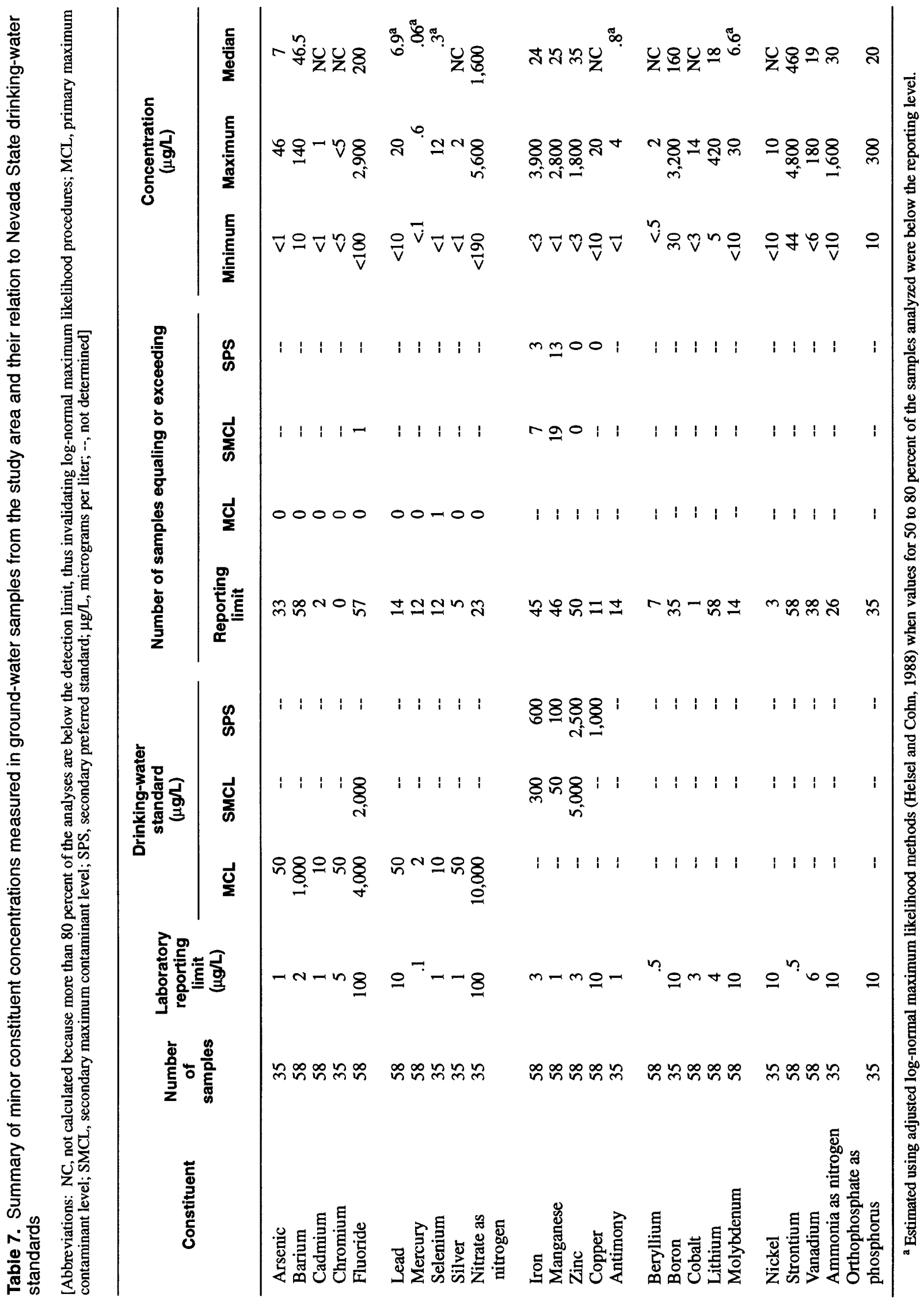


were not found. Although arsenic concentration did not exceed the MCL in any sample, water from sites 30 , 47, and 57 contained 33, 33, and $46 \mu \mathrm{g} / \mathrm{L}$ of arsenic, respectively. Fluoride $(2,900 \mu \mathrm{g} / \mathrm{L})$ exceeded the SMCL in a sample from a $120-\mathrm{ft}$ deep well in Dayton Valley (site 16). The highest concentrations of iron $(3,900 \mu \mathrm{g} / \mathrm{L})$ and manganese $(2,800 \mu \mathrm{g} / \mathrm{L})$ were measured in water from site 16 in Dayton Valley (figs. 22 and 23). The next highest concentrations of iron $(1,100 \mu \mathrm{g} / \mathrm{L})$ and manganese $(2,300$ and $1,900 \mu \mathrm{g} / \mathrm{L})$ were measured in water from sites 51,58 , and 60 in Churchill Valley. Two of the Churchill Valley sites were shallow wells located near the Carson River a short distance upstream from Lahontan Reservoir. Selenium exceeded the primary drinking-water standard in a sample from a 133-ft deep well in the southern part of Dayton Valley (site 17). Nitrate concentrations were all below the MCL and reached a maximum concentration of $5.6 \mathrm{mg} / \mathrm{L}$, as nitrogen.

Arsenic in ground-water samples from the study area ranged in concentration from less than 1 to $46 \mu \mathrm{g} / \mathrm{L}$. The concentration of arsenic is probably controlled by local redox conditions. In a similar hydrogeologic environment in the adjacent Carson Desert, dissolution of volcanic rock fragments and metal-oxide coatings is probably releasing arsenic to the ground water (M.S. Lico, U.S. Geological Survey, written commun., 1992). Lico and others (1986), Welch and Lico (1988), and Welch and others (1988) indicate that volcanic-rock fragments and metal-oxide coated grains have substantially higher arsenic concentrations than other grains, such as quartz and feldspar. Arsenic-bearing minerals have not been identified in basin-fill deposits of the study area, possibly due to the insensitivity of techniques used for mineral identification in this study. Processes controlling arsenic concentrations in basin-fill deposits in the Carson Desert are discussed by Welch and Lico (1988).

Fluoride is common in volcanic rocks and glass, in hornblende and micas of intrusive and metamorphic rocks, and in the more common minerals, such as fluorite and apatite (Hem, 1985, p. 121; Robertson, 1991, p. 17). Fluoride concentration in ground water can be controlled by (1) mineral-equilibrium reactions, (2) sorption or desorption, and (3) availability of fluorite in rocks (Robertson, 1991, p. 17). Fluoride in ground water in the study area probably originates from dissolution of fluorine-rich minerals and volcanic glass. Ground water is undersaturated with fluorite, so fluoride concentration may be controlled by adsorption, or availability of fluorine-containing minerals.

Iron and manganese concentrations are statistically correlated (Spearman's rho $\left(r_{s}\right)=0.60$, at the alpha $=0.05$ ). Spearman's rho is a nonparametric test that measures the monotonic relation between two variables (Conover, 1980, p. 252-256). Multiple correlation analysis of iron, manganese, and ammonium concentrations result in $\mathrm{r}=0.84$, at the alpha $=0.05$ level. Multiple correlation analysis of iron, manganese, ammonium, and dissolved oxygen did not show a significant correlation. This is probably because the reporting level for dissolved oxygen used in this report was $1.0 \mathrm{mg} / \mathrm{L}$, so that samples with high concentrations of iron, manganese, and ammonium generally contain dissolved oxygen concentration below the reporting level. The presence of water with high iron, manganese, and ammonium concentrations implies that dissolved oxygen is being consumed by nitrification. When all the dissolved oxygen is consumed, a reducing environment remains that can result in (1) the reduction of nitrate to ammonium and (2) the dissolution of iron and manganese oxides that coat mineral grains. These processes produce water with ammonium and relatively high concentrations of iron and manganese.

Selenium in ground-water samples in the study area generally was at concentrations less than the detection limit of $1 \mu \mathrm{g} / \mathrm{L}$ and reached a maximum concentration of $12 \mu \mathrm{g} / \mathrm{L}$. The likely sources of dissolved selenium are soils derived from marine sedimentary deposits (Gilliom and others, 1989), dissolution or oxidation of organic matter (Weres and others, 1989), and dissolution of iron and manganese oxides (Balistrieri and Chao, 1990). Concentration of selenium in the shallow sediment samples is generally less than $2 \mathrm{mg} / \mathrm{kg}$ in the study area (Elizabeth A. Frick, U.S. Geological Survey, written commun., 1992).

Concentrations of nitrate, ammonium, and phosphate in ground-water samples are low (table 7). The source of the nutrients is unknown. Sewage effluent from septic systems could be a source of nutrients in the samples, but none of the 8 samples containing nitrate concentration greater than $2 \mathrm{mg} / \mathrm{L}$ had measurable tritium (evidence of recent origin). In addition, 5 of these 8 samples have estimated ages ranging from 1,200 to 24,000 years (table 6); thus sewage 
effluent probably is not a source of nutrients in these waters. A more probable source is organic matter in the basin-fill deposits.

\section{Radionuclides}

Gross-alpha and gross-beta activities, radon-222, and dissolved uranium concentrations were measured in several samples from the study area (fig. 24). Gross alpha and beta (excluding radon and tritium, which were removed prior to counting) had median activities of 1.8 and 7.25 picocuries per liter $(\mathrm{pCi} / \mathrm{L})$ and ranged from 0.27 to 21 and 3.0 to $21 \mathrm{pCi} / \mathrm{L}$, respectively, in 35 samples (fig. 24). Alpha and beta activities are a general indication of the concentration of alpha- and beta-emitting radionuclides dissolved in the water, but these measurements do not indicate the source of the radiation. Median radon-222 concentration for 35 samples was $580 \mathrm{pCi} / \mathrm{L}$ and ranged from 150 to $1,800 \mathrm{pCi} / \mathrm{L}$. Median uranium concentration for 26 samples was $2.2 \mu \mathrm{g} / \mathrm{L}$ and ranged from 0.40 to $210 \mu \mathrm{g} / \mathrm{L}$ (fig. 24). Radium-226, measured in 3 samples, ranged from 0.04 to $0.10 \mathrm{pCi} / \mathrm{L}$. Radium-228, measured in 1 sample, was $1.0 \mathrm{pCi} / \mathrm{L}$. Although only 5 or 6 samples in the upland and shallow aquifers were analyzed for activities and radionuclide concentrations, these samples had the same range in activities and concentrations as samples from the principal aquifers, except uranium was higher (fig. 24).

Measurements of alpha and beta activities are used as screening methods for public-water supplies (U.S. Environmental Protection Agency, 1986b). The primary maximum contaminant levels (MCL's) proposed by the U.S. Environmental Protection Agency (1991) for radionuclides analyzed in this study are $15 \mathrm{pCi} / \mathrm{L}$ for adjusted gross-alpha activity (adjusted to exclude uranium and radium-226), $300 \mathrm{pCi} / \mathrm{L}$ for radon-222; $20 \mu \mathrm{g} / \mathrm{L}$ for dissolved uranium, and $20 \mathrm{pCi} / \mathrm{L}$ for radium-226 and radium-228. None of the 24 samples that had both alpha and uranium analyses exceed the proposed gross-alpha MCL. Twenty-seven of 35 samples exceeded the proposed radon-222 MCL. Three of 26 samples exceeded the proposed uranium MCL. None of the 3 radium-226 analyses or the radium-228 analysis exceeded the proposed MCL.

Gross-alpha activity in the ground- water samples is primarily from the radioactive decay of uranium dissolved in the water (fig. 25). Alpha activity in 20 of the 24 samples with both alpha and uranium analyses was produced entirely by uranium decay. This assumes an activity ratio (AR) of uranium-234 to uranium -238 of 1.0 to 1.5 , as was measured in most samples throughout the Carson River Basin (Thomas and others, 1993), and that uranium-234 and uranium-238 made up most of the dissolved uranium. Uranium-235 is less than 5 percent of the total dissolved uranium in 38 samples analyzed for all three uranium isotopes in the Carson River Basin (Thomas and others, 1993). The most likely sources of the dissolved uranium are uraniumrich organic matter and metal-oxide coatings on mineral grains. Dissolution of the metal-oxide coatings, desorption from coatings and organic matter, and oxidation of organic matter can release uranium to the water (Szalay, 1964; Langmuir, 1978; Nakashima and others, 1984; Hsi and Langmuir, 1985; Kamineni, 1986; Leventhal and others, 1986). Some of the dissolved uranium probably originated from dissolution of uranium-rich silicic volcanic and granitic rocks in the recharge areas and underlying the basin-fill aquifers (fig. 3). Alpha-emitting radionuclides other than uranium also may be present in small concentrations in the - ground water. For example, radium-226 contributed some alpha activity to the ground-water samples. Radium-226 ranged from 0.04 to $0.10 \mathrm{pCi} / \mathrm{L}$ in three samples and probably was present in similar concentrations in other samples (in 55 samples throughout the entire Carson River Basin, radium-226 ranged from 0.02 to $2.1 \mathrm{pCi} / \mathrm{L}$; Thomas and others, 1993).

Gross-beta activity in the ground water is primarily from potassium- 40 dissolved in the ground water and the ingrowth of uranium-238 progeny in the sample before analysis. The main source of dissolved potassium probably is dissolution of potassium feldspar and biotite (see section titled "Modeling of Geochemical Reactions"). In addition, some potassium may be added to the water by cation exchange. Generally, radioactive decay of dissolved potassium- 40 does not account for all the beta activity in the samples (fig. 26). An activity line for potassium-40 was used to estimate the amount of beta activity produced by potassium-40 dissolved in the water and was calculated by multiplying the potassium concentration by 0.818 (a natural abundance of 0.0117 percent and a half life of $1.28 \times 10^{9}$ years was assumed; Friedlander and others, 1981, p. 612). The most likely source of the unaccounted-for beta activity was the ingrowth of uranium238 progeny in the sample before analysis (samples are generally stored more than 100 days between collection and drying for analysis). In approximately 


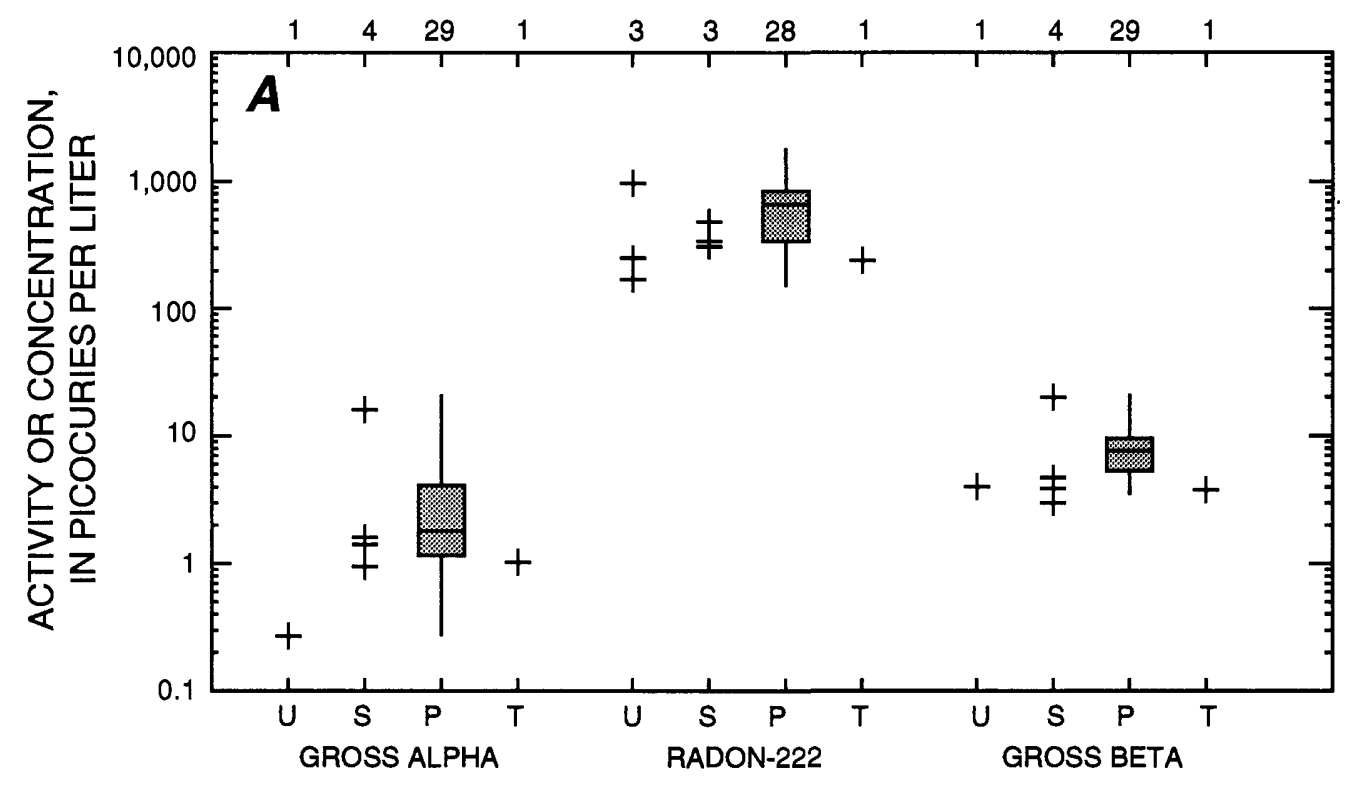

EXPLANATION

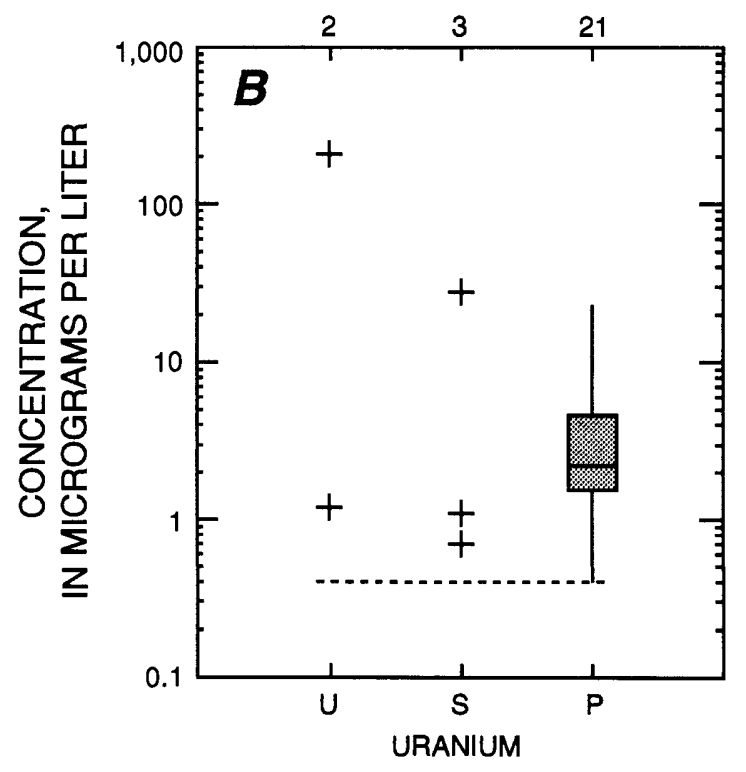

29 NUMBER OF ANALYSES

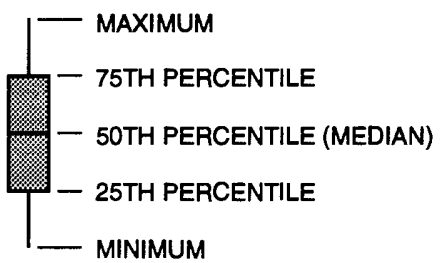

-...- DETECTION LIMIT

+ single value

$U$ UPLAND AQUIFER

S SHALLOW AQUIFER

P PRINCIPAL AQUIFER

T THERMAL AQUIFER

Figure 24. $A$, gross-alpha and beta activities and radon-222 concentrations, and $B$, uranium concentrations in ground-water samples from Dayton, Stagecoach, and Churchill Valleys.

100 days, thorium-234 and protactinium-234 would grow in the sample in an amount equal to the parent uranium-238, assuming a uranium-234 to uranium-238 activity ratio of 1.0 . Because uranium- 238 has two progeny, the amount of beta activity from this ingrowth would be about equal to the activity of the total dissolved uranium. For higher activity ratios uranium-238 is proportionately less than uranium-234 and therefore ingrowth would be less, as compared to the total dissolved uranium. Ingrowth of uranium-238 progeny in the sample could account for most of the beta activity above that produced by the decay of potassium- 40 (Thomas and others, 1993) as shown in figure 27. Other beta-emitting radionuclides, such as radium-228 [1.0 $\mathrm{pCi} / \mathrm{L}$ in 1 sample from this study and 1.0 to $4.6 \mathrm{pCi} / \mathrm{L}$ in 34 samples throughout the Carson River 
Basin (Thomas and others, in press)] and lead-210 [0.45 to $12 \mathrm{pCi} / \mathrm{L}$ in 7 samples in the Carson Desert (Thomas and others, 1993)] also contribute beta activity to the ground water.

Radon-222 is a product of the decay of radium226 in the aquifer material, rather than dissolved radium-226. Maximum radium-226 concentration for 55 samples in the entire Carson River Basin was only $2.1 \mathrm{pCi} / \mathrm{L}$ (Thomas and others, 1993), whereas radon222 ranged from 150 to $1,800 \mathrm{pCi} / \mathrm{L}$ in the study area.

For a more detailed discussion of processes affecting the concentration of radionuclides in the Carson River Basin, see Thomas and others (1993).

\section{Synthetic Organic Compounds}

Ground-water samples from the study area were analyzed for 61 synthetic organic compounds. These compounds represent four classes of organic compounds: (1) carbamate insecticides (for example, carbofuran), (2) triazine herbicides (for example, atrazine), (3) chlorophenoxy acid herbicides (for example, 2,4-D), and (4) volatile organics (for example, benzene). Only 3 of these 61 compounds were detected in ground-water samples collected during the study period (table 8) and none exceeded Nevada State drinking-water standards. Samples from sites 5 and 9 (fig. 2) contained tetrachloroethylene (PCE) at concentrations

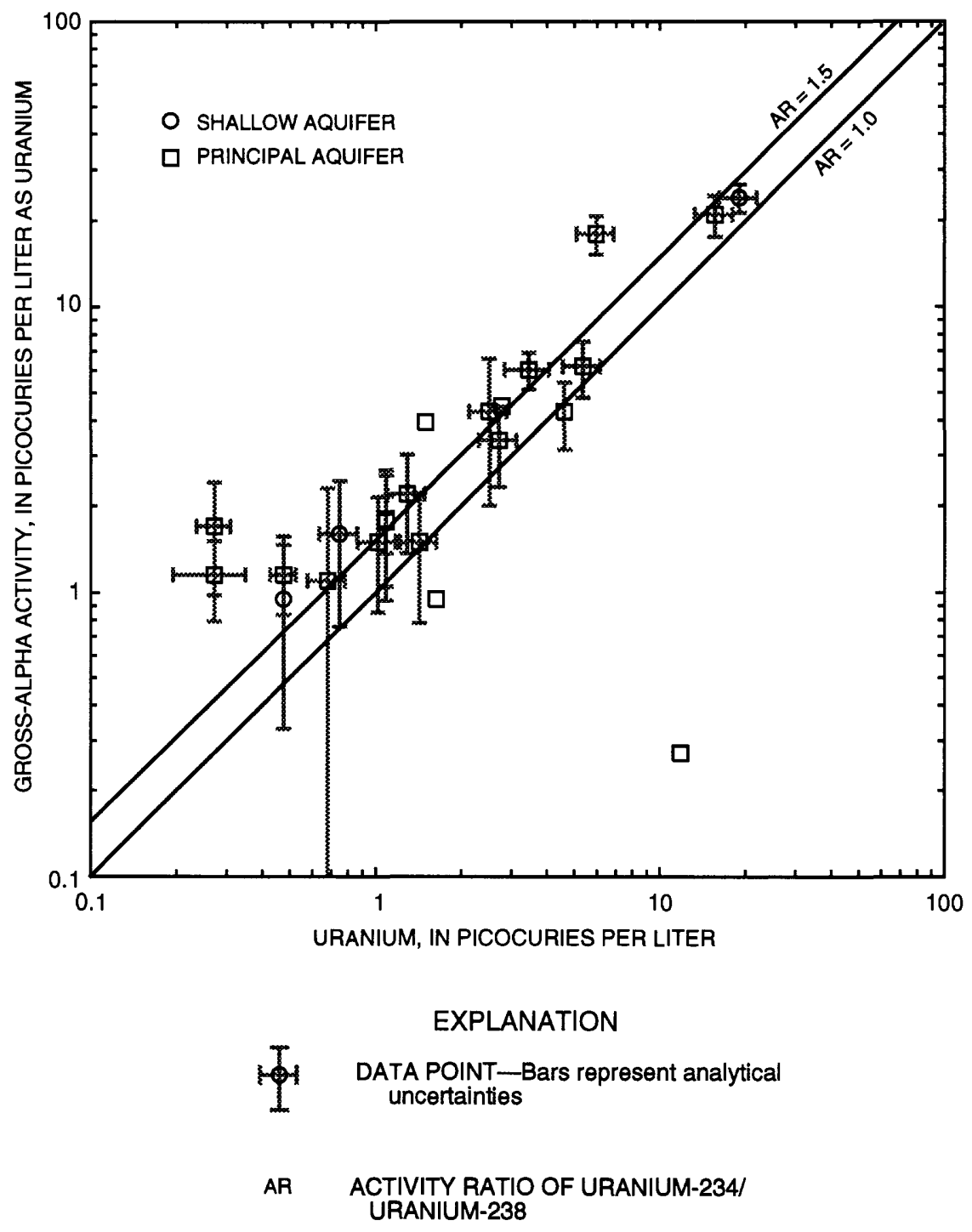

Figure 25. Relation between uranium concentration and gross-alpha activity in ground-water samples from Dayton, Stagecoach, and Churchill Valleys. 
of 0.5 and $0.2 \mu \mathrm{g} / \mathrm{L}$, respectively; the sample from site 5 also contained 1,1,1-trichloroethane (TCA) at a concentration of $0.3 \mu \mathrm{g} / \mathrm{L}$. A sample from site 11 (fig. 2A) contained the chlorophenoxy acid herbicide dicamba at the reporting limit of $0.01 \mu \mathrm{g} / \mathrm{L}$; a subsequent sample contained no dicamba.

Wells at sites 5 and 9 had relatively shallow depths to water, $30 \mathrm{ft}$ in an 82-ft deep well and $55 \mathrm{ft}$ in a 180-ft deep well, and were in areas near some industrial and commercial activity, so PCE and TCA could be present in the aquifer near the well. PCE and TCA are among the most commonly measured organic contaminants in ground water (Plumb, 1991). PCE is a general-purpose degreasing agent used to clean automobile engines, septic tanks, cooking grease in kitchens, and in dry cleaning. TCA is also used as a degreasing agent, and is commonly used as a solvent in many industrial processes and household products. The well at site 11 is shallow (17.5 ft deep) and is in a field that is flood irrigated for growing alfalfa and winter wheat. The well is $30 \mathrm{ft}$ from a large irrigation ditch where dicamba could have been used for weed control. Dicamba is a post-emergent herbicide used to control broadleaf weeds for noncrop and grain-crop applications.

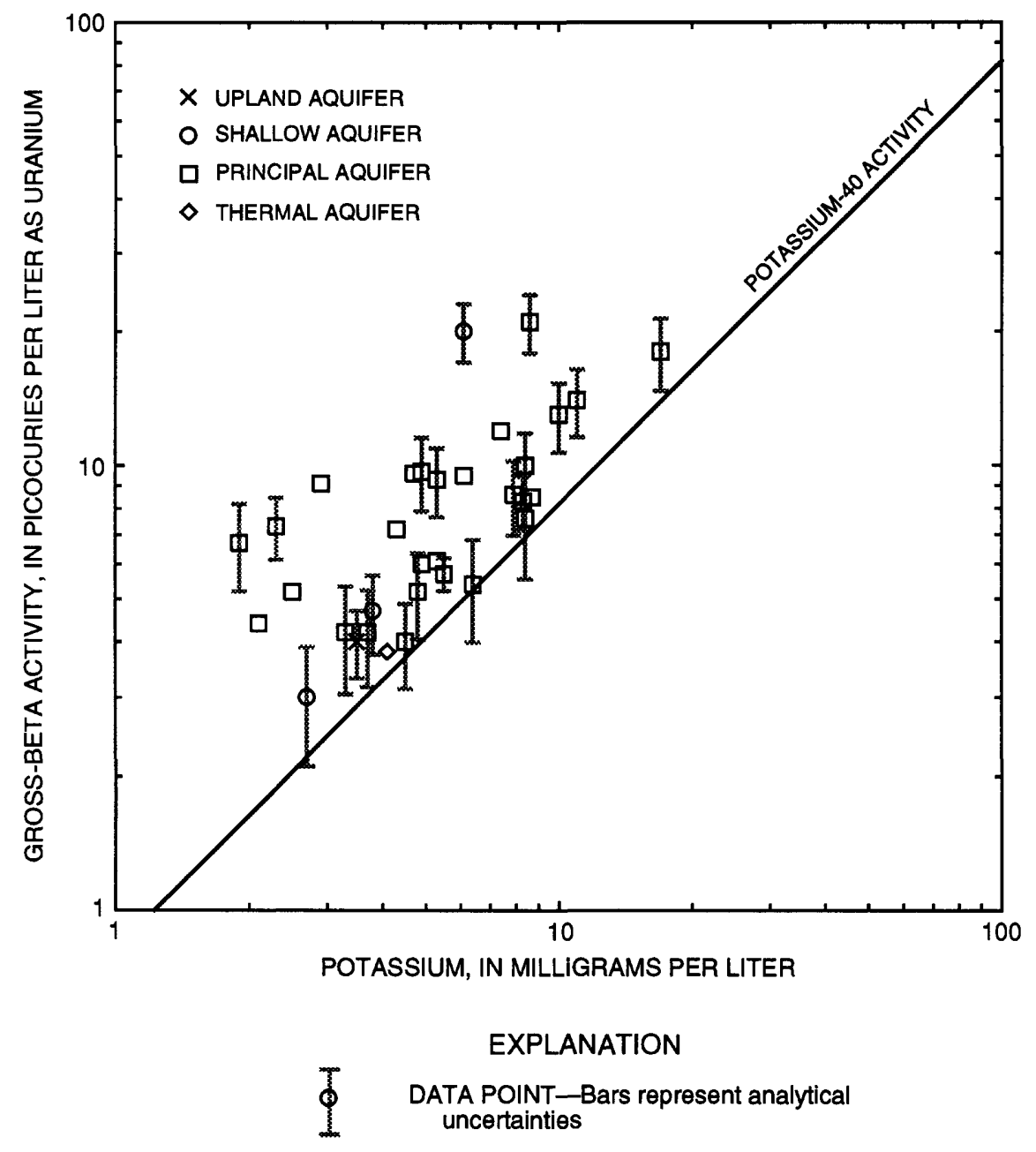

Figure 26. Relation between potassium concentration and gross-beta activity in ground-water samples from Dayton, Stagecoach, and Churchill Valleys. The potassium- 40 activity line is the amount of beta activity estimated to be produced by potassium- 40 dissolved in the water and was calculated by multiplying the potassium concentration by 0.818 (assuming a natural abundance of 0.0117 percent and a half life of $1.28 \times 10^{9}$ years; Friedlander and others, 1981, p. 612). 

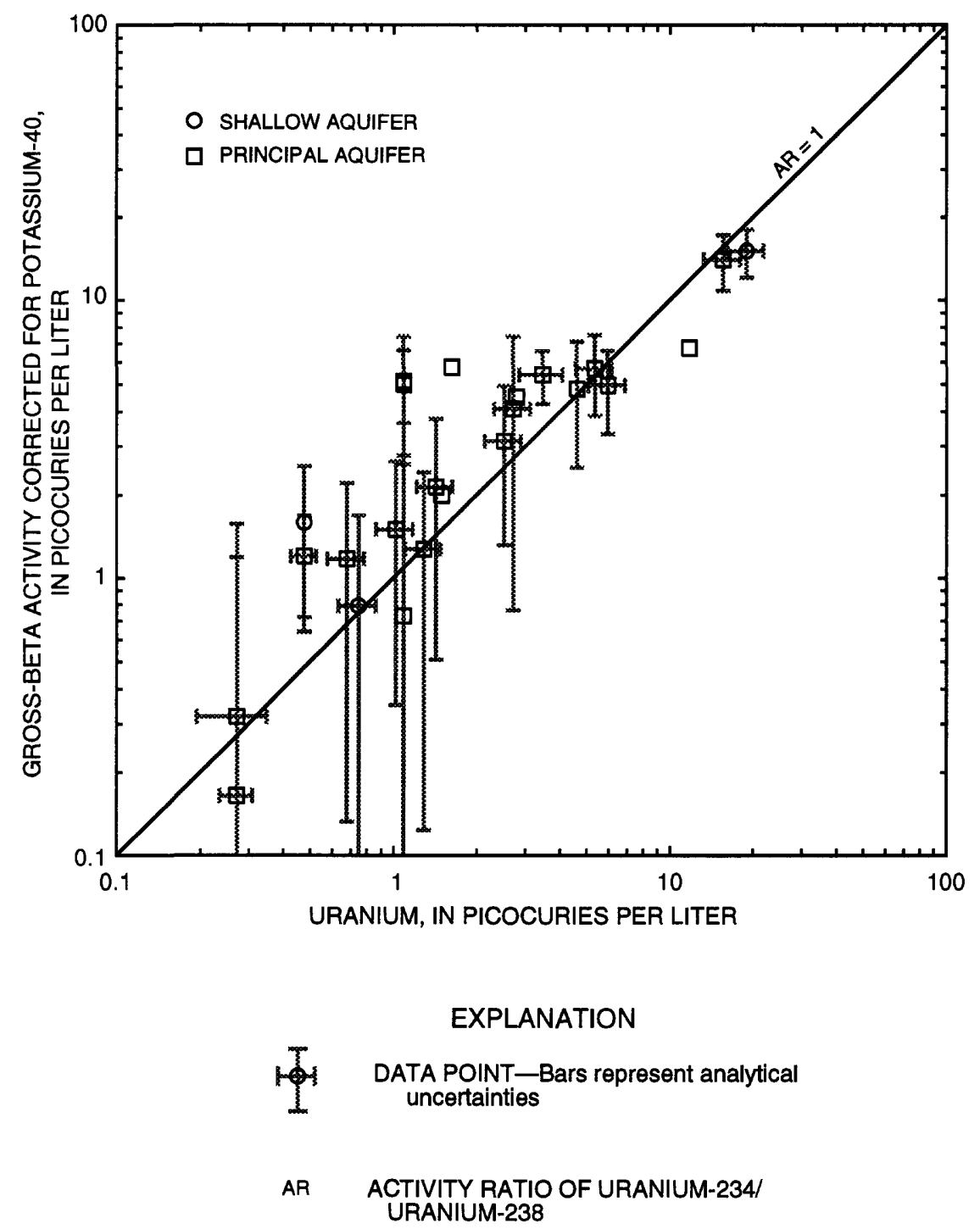

Figure 27. Relation between uranium concentration and gross-beta activity corrected for the contribution of potassium- 40 (beta activity contributed by potassium-40 is subtracted from the gross-beta activity) in ground-water samples from Dayton, Stagecoach, and Churchill Valleys.

The synthetic organic compounds detected in the study may not represent actual ground-water conditions in the area because of sample contamination or an analytical problem. Sample contamination can be caused by (1) sample collection and handling, where the sample comes in contact with organic compounds on sampling equipment, or the sample is near organic compounds in storage or in areas where the compound is used; and (2) well-construction practices that are incompatible with the sampling of organic compounds, such as the use of organic-based drilling fluids, the use of unclean polyvinyl chloride (PVC) well casing, or the use of PVC cement to connect sections of PVC pipe.
Vinyl chloride may contaminate samples from wells where PVC cement was used because vinyl chloride is a major ingredient in PVC cement. Phthalate esters are used in the manufacture of PVC pipe and remain on the pipe until it is cleaned with detergent. The presence of as little as $2.3 \mathrm{mg} / \mathrm{L}$ of dissolved organic carbon, mainly from natural organic compounds (humic and fulvic acids), can result in the incorrect identification of dicamba because of the analytical ambiguity caused by the presence of natural organic acids.

In order to distinguish sample contamination from ground-water contamination, quality-control measures were incorporated in the sampling protocols. 
Table 8. Summary of synthetic compounds measured in ground-water samples from the study area

[Abbreviations: NA, not available because edited values comprise 80 percent of more of the total analyses, thus invalidating log-normal maximum likelihood procedures. MCL, primary maximum contaminant level; $\mu \mathrm{g} / \mathrm{L}$, micrograms per liter; --, not determined]

\begin{tabular}{|c|c|c|c|c|c|c|c|c|}
\hline \multirow{2}{*}{ Constituent } & \multirow{2}{*}{$\begin{array}{l}\text { Number } \\
\text { of } \\
\text { samples }\end{array}$} & \multirow{2}{*}{$\begin{array}{c}\text { Laboratory } \\
\text { reporting } \\
\text { limit } \\
(\mu g / L)\end{array}$} & \multirow{2}{*}{$\begin{array}{c}\begin{array}{c}\text { Drinking- } \\
\text { water } \\
\text { standard } \\
(\mu g / L)\end{array} \\
\text { MCL }\end{array}$} & \multicolumn{2}{|c|}{$\begin{array}{c}\text { Number of } \\
\text { samples exceeding }\end{array}$} & \multicolumn{3}{|c|}{$\begin{array}{c}\text { Concentration } \\
(\mu g / L)\end{array}$} \\
\hline & & & & $\begin{array}{c}\text { Reporting } \\
\text { ilmit }\end{array}$ & MCL & Minimum & Maximum & Median \\
\hline $\begin{array}{l}\text { 1,1,1-Trichloroethane } \\
\text { (TCA) }\end{array}$ & 31 & 0.2 & 200 & 1 & 0 & $<0.3$ & 0.3 & NA \\
\hline $\begin{array}{l}\text { Tetrachloroethylene } \\
\text { (PCE) }\end{array}$ & 31 & .2 & -- & 2 & -- & $<.2$ & .5 & NA \\
\hline Dicamba & 6 & .01 & -- & 1 & -- & $<.01$ & .01 & NA \\
\hline
\end{tabular}

These measures included using equipment blanks (blanks are water containing no detectable organic compounds) to identify organic compounds added to the sample by sampling equipment, trip blanks (blanks shipped with the ground-water samples to the laboratory) to account for organic compounds entering samples by airborne routes, and "spiked" samples (known amounts of an organic compound are added to a sample to identify loss by volatilization or degradation of the compounds after sample collection). Results of quality-control measures show that the synthetic organic data are accurate. A discussion of the quality-control data is given by Whitney (1994).

The source of the identified organic compounds is unknown, but some industrial and commercial activities in the study area probably use PCE and TCA. Dicamba may be used for weed control in the study area. Ground-water contaminated by synthetic organic compounds should have a young component because most of these compounds have been developed since World War II. Tritium was detected in samples from two of the three sites, indicating a young age. A sample at site 9 contained $27 \mathrm{pCi} / \mathrm{L}$ of tritium (and 109 percent modern carbon), indicating that this sample contained recently recharged ground water. Thus, water in the aquifer near this site may have been contaminated by PCE. A sample at site 5 contained less than $0.3 \mathrm{pCi} / \mathrm{L}$ of tritium, indicating that the water in this well was recharged more than 57 years ago. Thus, the PCE and
TCA measured in this sample may be from sample contamination and may not be present in the aquifer in this area. Tritium was not measured at site 11 .

\section{SUMMARY AND CONCLUSIONS}

This report describes the quality of surface and ground waters and the processes that produce the chemical and isotopic compositions of ground water in aquifers of the Carson River Basin pilot NAWQA project study area. The description of water quality includes major and minor inorganic constituents, radionuclides, and manmade organic compounds. A detailed discussion of physical and geochemical processes that produce the ground-water chemistry in aquifers in the study area is also given.

Dayton, Stagecoach, and Churchill Valleys are in the central part of the Carson River Basin. The valleys consist of basins filled with unconsolidated deposits bordered by mountain ranges. The mountains are primarily volcanic rock. Water use in all three valleys in 1990 was about 12,000 acre-ft of ground water and about 22,000 acre-ft of surface water. Average annual flow of the Carson River into the study area is estimated to be 272,000 acre-ft.

Most ground water used in Dayton, Stagecoach, and Churchill Valleys is pumped from principal aquifers in basin-fill deposits. The deposits are unconsolidated and semiconsolidated alluvial, fluvial, and lacustrine material in extensional basins that reach a 
maximum depth of approximately $3,000 \mathrm{ft}$. Ground water in the principal aquifers originates as precipitation in the adjacent mountains, as surface water in the Carson River, and as subsurface flow from adjacent valleys. Ground-water flow in the study area is generally parallel to the direction of surface-water flow in the Carson River. Ground water is discharged by pumping, evapotranspiration, and subsurface flow into the Carson River.

Ground water in some wells near the Carson River is a mixture of water recharged from the river and the adjacent principal aquifer. The mixing of surface and ground waters is indicated by the water chemistry; the stable isotopes deuterium, carbon-13, and sulfur34 ; and the radioactive isotopes tritium and carbon-14.

In general, the quality of ground water in the study area meets Nevada State drinking-water standards and is acceptable for most uses. The chemical composition of ground water is variable, with the most dominant type being mixed cations and bicarbonate for about half of the ground water sampled. Dissolvedsolids concentrations range from 200 to $1,700 \mathrm{mg} / \mathrm{L}$, and have a median of $380 \mathrm{mg} / \mathrm{L}$. The chemical composition of the Carson River is a mixed cation-anion water and is independent of streamflow. Low flows (less than or equal to $33.5 \mathrm{ft}^{3} / \mathrm{s}, 25$ th percentile) contained the highest constituent concentrations and high flows (equal to or greater than, $461 \mathrm{ft}^{3} / \mathrm{s}, 75 \mathrm{th}$ percentile) contained the most dilute constituent concentrations.

Geochemical models, do not provide unique solutions, but they indicate that (1) plagioclase feldspar, sodium chloride, gypsum (or pyrite), potassium feldspar, and biotite dissolve; (2) calcite precipitates; (3) kaolinite forms; (4) small amounts of calcium and magnesium in the water exchange for potassium on aquifer matrix minerals; and (5) $\mathrm{CO}_{2}$ gas dissolves, or exsolves, as ground water moves from upland aquifers in mountainous recharge areas to principal aquifers in basin-fill deposits. Additionally, models for Dayton Valley include the formation of sodium beidellite and the exchange of calcium in the water for sodium on clays. Models for Stagecoach and Churchill Valley also include precipitation of silica. Models were consistent with (1) phases identified in basin-fill sediments of Dayton, Stagecoach, and Churchill Valleys;

(2) chemical activity of major cations and silica;

(3) saturation indices of calcite and amorphous silica;

(4) phase relations for aluminosilicate minerals indicated by activity diagrams; and (5) optical, X-ray diffraction, and scanning-electron microscopy observations of mineral grains in the aquifer sediments.

Sulfur-isotopic composition of ground-water samples also support the general geochemical models for the study area.

Carbon-isotopic data were used to estimate ages of the ground water. Estimated age ranges from modern to 24,000 years using the closed-system model of Ingerson and Pearson (1964). Samples that were a mixture of Carson River and ground water are all estimated to be modern in age.

In ground-water samples collected during the study, 25 minor constituents were measured. Only one sample contained a constituent (selenium) that exceeded Nevada's primary drinking-water standards. Nevada's secondary-drinking water standards were exceeded in 1 sample for fluoride, 7 samples for iron, and 19 samples for manganese. Minor constituents and nutrient concentrations varied widely throughout the study area. Minor constituents concentrations are generally controlled by local redox conditions, and originate primarily from minerals in volcanic and marine sedimentary rocks, metal-oxide coatings on mineral grains, and organic matter. Nutrients are probably from organic matter buried in the sediments.

Radionuclide analyses for this study included gross-alpha activity, gross-beta activity, radon-222, uranium, radium-226, and radium-228. None of the 24 samples that had both alpha and uranium analyses exceeded the proposed adjusted gross-alpha MCL of $15 \mathrm{pCi} / \mathrm{L}$. Of 35 samples analyzed for radon-222, 27 exceeded the proposed MCL of $300 \mathrm{pCi} / \mathrm{L}$. Of 26 samples analyzed for uranium, 3 exceeded the proposed MCL of $20 \mu \mathrm{g} / \mathrm{L}$. None of the three radium-226 analyses or the radium-228 analysis exceeded the proposed MCL of $20 \mathrm{pCi} / \mathrm{L}$. Gross-alpha and gross-beta activities ranged from 0.27 to 21 and 3.0 to $21 \mathrm{pCi} / \mathrm{L}$, with median activities of 1.8 and $7.25 \mathrm{pCi} / \mathrm{L}$, respectively. Gross-alpha activity was primarily from uranium dissolved in the water. The most likely sources of dissolved uranium are the dissolution of uranium-rich metal-oxide coatings, desorption from coatings and organic matter, and oxidation of uraniferous organic matter. Radon-222 ranged from 150 to $1,800 \mathrm{pCi} / \mathrm{L}$, had a median concentration of $580 \mathrm{pCi} / \mathrm{L}$, and was produced by the decay of radium-226 in solid phases in the aquifer. Gross-beta activity was primarily from the decay of potassium- 40 dissolved in the ground water and the ingrowth of uranium-238 progeny in the 
sample before analysis. The most likely source of potassium- 40 is the dissolution of potassium feldspar and biotite.

Ground-water samples from Dayton, Stagecoach, and Churchill Valleys were analyzed for 61 synthetic organic compounds. Only 3 compounds-PCE, TCA, and dicamba-were detected and none of these exceeded Nevada's drinking-water standards. The PCE and TCA are degreasing agents and could be from industrial and commercial activities in the study area. Dicamba is a broad-leaf herbicide and may be used for weed control in the study area.

\section{REFERENCES CITED}

Arteaga, F.E., and Durbin, T.J., 1978, Development of a relation for steady-state pumping rate for Eagle Valley ground-water basin, Nevada: U.S. Geological Survey Open-File Report 79-261, 44 p.

Balistrieri, L.S., and Chao, T.T., 1990, Adsorption of selenium by amorphous iron oxyhydroxide and manganese dioxide: Geochimica et Cosmochimica Acta, v. 54, p. 739-751.

Ball, J.W., Nordstrom, D.K., and Zachmann, D.W., 1987, WATEQ4F-A personal computer FORTRAN translation of the geochemical model WATEQ2 with revised data base: U.S. Geological Survey Open-File Report 87-50, $108 \mathrm{p}$.

Barnes, Ivan, 1964, Field determination of alkalinity and $\mathrm{pH}$ : U.S. Geological Survey Water-Supply Paper 1535-H, $17 \mathrm{p}$.

Benson, L.V., and Thompson, R.S., 1987, Lake-level variation in the Lahontan Basin for the past 50,000 years: Quaternary Research, v. 28, p. 69-85.

Bingler, E.C., 1977, Geologic map of the New Empire quadrangle: Nevada Bureau of Mines and Geology Map 59, scale $1: 24,000$.

Bonham, H.F., 1969, Geology and mineral deposits of Washoe and Storey Counties, Nevada: Nevada Bureau of Mines Bulletin 70, $140 \mathrm{p}$.

Cerling, T.E., 1984, The stable isotopic composition of modern soil carbonate and its relationship to climate: Earth and Planetary Science Letters, v. 71, p. 229-240.

Claypool, G.E., Holser, W.T., Kaplan, I.R., Sakai, H., and Zak, I., 1980, The age curves of sulfur and oxygen isotopes in marine sulfate and their mutual interpretation: Chemical Geology, v. 28, p. 199-260.

Conover, W.J., 1980, Practical nonparametric statistics (2d ed.): New York, John Wiley, 493 p.

Craig, Harmon, 1961, Isotopic variations in meteoric waters: Science, v. 133, no. 3465, p. 1702-1703.
Dangberg, Grace, 1972, Carson Valley-Historical sketches of Nevada's first settlement: Carson Valley Historical Society, $144 \mathrm{p}$.

Deer, W.A., Howie, R.A., and Zussman, J., 1966, An introduction to the rock-forming minerals: London, Longmans, Green and Co., 528 p.

Deines, Peter, 1980, The isotopic composition of reduced organic carbon, in Fritz, Peter, and Fontes, JeanCharles, eds., 1980, Handbook of environmental isotope geochemistry: New York, Elsevier, v. 1, p. 329406.

Drever, J. I., 1988, The geochemistry of natural waters (2d ed:): Englewood Cliffs, N.J., Prentice-Hall, 437 p.

Fishman, M.J., and Friedman, L.C., 1989, Methods for determination of inorganic substances in water and fluvial sediments: U.S. Geological Survey Techniques of Water-Resources Investigations, Book 5, Chap. A1, $545 \mathrm{p}$.

Friedlander, G., Kennedy, J.W., Macias, E.S. and Miller, J.M., 1981, Nuclear and radiochemistry (3d ed.): New York, John Wiley, 684 p.

Fritz, Peter, and Fontes, Jean-Charles, eds., 1980, Handbook of environmental isotope geochemistryThe terrestrial environment: New York, Elsevier, v. $1,545 \mathrm{p}$.

Garrels, R.M., and MacKenzie, F.T., 1967, Origin of the chemical compositions of some springs and lakes: American Chemical Society, Advances in Chemistry Series, no. 67 , chapter 10 , p. $222-242$.

Gilliom, R.J., and others, 1989, Preliminary assessment of sources, distribution, and mobility of selenium in the San Joaquin Valley, California: U.S. Geological Survey Water-Resources Investigations Report 88-4186, 129 p.

Glancy, P.A., and Katzer, T.L., 1976, Water-resources appraisal of the Carson River Basin, western Nevada: Nevada Division of Water Resources Reconnaissance Report 59, $126 \mathrm{p}$.

Greene, R.C., Stewart, J.H., John, D.A., Hardyman, R.F., Silberling, J.J., and Sorensen, M.L., 1991, Geologic map of the Reno $1^{\circ}$ by $2^{\circ}$ quadrangle, Nevada and California: U.S. Geological Survey Miscellaneous Field Studies Map MF-2154-A, scale 1:250,000.

Graf von Reichenbach, H., and Rich, C.I., 1975, Finegrained micas in soils, in Gieseking, J.E., ed., Soil components-Inorganic components: New York, SpringerVerlag, v. 2, chap. 3, p. 59-88.

Hardy, M.A., Leahy, P.P., and Alley, W.M., 1989, Well installation and documentation, and ground-water sampling protocols for the pilot National Water-Quality Assessment Program: U.S. Geological Survey Open-File Report 89-396, $36 \mathrm{p}$.

Harrill, J.R., Welch, A.H., and Preissler, A.M., 1984, Hydrogeologic controls on ground-water flow in Stagecoach Valley, Nevada, in Lintz, Joseph, Jr., ed., Western geo- 
logical excursions [in conjunction with 1984 annual meetings of Geological Society of America and affiliated societies]: University of Nevada, Reno, Mackay School of Mines, v. 3, p. 117-120.

1992, Hydrogeochemical evidence for subsurface inflow to Stagecoach Valley, Lyon County, Nevada, in Subitzky, Seymour, ed., Selected papers in the hydrologic sciences, 1988-92: U.S. Geological Survey Water-Supply Paper 2340, p. 179-193.

Helsel, D.R., and Cohn, T.A., 1988, Estimation of descriptive statistics for multiple censored water-quality data: Water Resources Research, v. 24, no, 12, p. 1997-2004.

Hem, J.D., 1985, Study and interpretation of the chemical characteristics of natural water ( $3 \mathrm{~d}$ ed.): U.S. Geological Survey Water-Supply Paper 2254, 283 p.

Hirsch, R.M., Alley, W.M., and Wilber, W.G., 1988, Concepts for a National Water-Quality Assessment Program: U.S. Geological Survey Circular 1021, 42 p.

Houghton, J.G., Sakamoto, C.M., and Gifford, R.O., 1975, Nevada's weather and climate: Nevada Bureau of Mines and Geology, Special Publication 2, 78 p.

Hsi, C.K.D., and Langmuir, Donald, 1985, Adsorption of uranyl onto ferric oxyhydroxides-Application of the surface complexation site-binding model: Geochimica et Cosmochimica Acta, v. 49, p. 1931-1941.

Ingerson, Earl, and Pearson, F.J., Jr., 1964, Estimation of age and rate of motion of groundwater by the ${ }^{14} \mathrm{C}$ method, in Recent researches in the fields of hydrosphere, atmosphere and nuclear geochemistry: Maruzen, Tokyo, Sugawara Festival Volume, p. 263-283.

Ishihara, Shunso, and Sasaki, Akira, 1989, Sulfur isotopic ratios of the magnetic-series and ilmenite series granitoids of the Sierra Nevada batholith-A reconnaissance study: Geology, v. 17, no. 9, p. 788-791.

Kamineni, D.C., 1986, Distribution of uranium, thorium and rare-earth elements in the Eye-Dashwa Lakes PlutonA study of some analogue elements: Chemical Geology, v. 55, p. 361-373.

Krouse, H.R., 1980, Sulphur isotopes in our environment, in Fritz, Peter, and Fontes, Jean-Charles, eds., Handbook of environmental isotope geochemistry: New York, Elsevier, v. 1, p. 435-472.

Langmuir, Donald, 1978, Uranium solution-mineral equilibria at low temperatures with applications to sedimentary ore deposits: Geochimica et Cosmochimica Acta, v. 42, p. 547-569.

Leventhal, J.S., Daws, T.A., and Frye, J.S., 1986, Organic geochemical analysis of sedimentary organic matter associated with uranium: Applied Geochemistry, v. 1, no. 2, p. 241-247.

Lico, M.S., Kharaka, Y.K., Carothers, W.W., and Wright, V.A., 1982, Methods for collection and analysis of geopressured geothermal and oil-field waters: U.S. Geological Survey Water-Supply Paper 2194, 21 p.
Lico, M.S., Welch, A.H., and Hughes, J.L., 1986, Lithologic and chemical data for sediments at two sites in the shallow alluvial aquifer near Fallon, Churchill County, Nevada, 1984-85: U.S. Geological Survey Open-File Report 86-250, $43 \mathrm{p}$.

Mattraw, H.C., Jr., Wilber, W.G., and Alley, W.M., 1989, Quality-assurance plan for the pilot National WaterQuality Assessment Program: U.S. Geological Survey Open-File Report 88-726, 21 p.

May, H.M., Kinniburgh, D.G., Helmke, P.A., and Jackson, M.L., 1986, Aqueous dissolution, solubilities, and thermodynamic stabilities of common aluminosilicate clay minerals-Kaolinite and smectites: Geochimica et Cosmochimica Acta, v. 50, p. 1667-1677.

Mazor, Emanuel, 1991, Applied chemical and isotopic groundwater hydrology: New York, Halsted Press, $274 \mathrm{p}$.

Moore, J.G., 1969, Geology and mineral deposits of Lyon, Douglas, and Ormsby Counties, Nevada: Nevada Bureau of Mines Bulletin 75, $45 \mathrm{p}$.

Nakashima, S., Disnar, J.R., Perruchot, A., and Trichet, J., 1984, Experimental study of mechanisms of fixation and reduction of uranium by sedimentary organic matter under diagenetic or hydrothermal conditions: Geochimica et Cosmochimica Acta, v. 48, p. 2321-2329.

Nevada Bureau of Consumer Health Protection Services, 1980, Water supply regulations-Part 1, water quality standards-monitoring, record keeping, and reporting: Nevada Division of Health, $27 \mathrm{p}$.

Parkhurst, D.L., Plummer, L.N., and Thorstenson, D.C., 1982, BALANCE-A computer program for calculating mass transfer for geochemical reactions in groundwater: U.S. Geological Survey Open-File Report 82-14, 29 p.

Plumb, R.H., Jr., 1991, The occurrence of Appendix IX organic constituents in disposal site groundwater: Groundwater Monitoring Review, v. XI, no. 2, p. 157-164.

Plummer, L.N., Parkhurst, D.L., and Thorstenson, D.C., 1983, Development of reaction models for groundwater systems: Geochimica et Cosmochimica Acta, v. 47 , p. $665-686$.

Rice, C.A., and Tuttle, M.L., 1989, Sulfur speciation and isotopic analyses of sediment samples from Walker Lake, Nevada: U.S. Geological Survey Open-File Report 89-4, $12 \mathrm{p}$.

Robertson, F.N., 1991, Geochemistry of ground water in alluvial basins of Arizona and adjacent parts of Nevada, New Mexico, and California: U.S. Geological Survey Professional Paper 1406-C, $90 \mathrm{p}$.

Rush, F.E., 1968, Index of hydrographic areas in Nevada: Nevada Division of Water Resources Information Report 6, 38 p. 
Schaefer, D.H., and Whitney, Rita, 1992, Geological framework and ground-water conditions in basin-fill aquifers of the Dayton Valley and Churchill Valley hydrographic areas, western Nevada: U.S. Geological Survey WaterResources Investigations Report 91-4072, 12 p.

Szalay, A., 1964, Cation exchange properties of humic acids and their importance in the geochemical enrichment of other cations: Geochimica et Cosmochimica Acta, v. 28, p. 1605-1614.

Thatcher, L.L., Janzer, V.J., and Edwards, K.W., 1977, Methods for determination of radioactive substances in water and fluvial sediments: U.S. Geological Survey Techniques of Water-Resources Investigations, Book 5, Chap. A5, 95 p.

Thomas, J.M., Welch, A.H., Lico, M.S., Hughes, J.L., and Whitney, Rita, 1993, Radionuclides in ground water of the Carson River Basin, western Nevada and eastern California, U.S.A.: Applied Geochemistry, v. 8, p. 447-471.

Thorstenson, D.C., Fisher, D.W., and Croft, M.G., 1979, The geochemistry of the Fox Hills-Basal Hell Creek aquifer in southwestern North Dakota and northwestern South Dakota: Water Resources Research, v. 15, no. 6, p. 1479-1498.

Thorstenson, D.C., Weeks, E.P., Haas, Herbert, and Woodward, J.C., 1990, Physical and chemical characteristics of topographically affected airflow in an open borehole at Yucca Mountain, Nevada: Proceedings of the Topical Meeting on Nuclear Waste Isolation in the Unsaturated Zone Focus '89, Sept. 17-21, 1989, p. 256-270.

Tidball, R.R., Briggs, P.H., Stewart, K.C., Vaughn, R.B., and Welsch, E.P., 1991, Analytical data for soil and well core samples from the Carson River Basin, Lyon and Churchill Counties, Nevada: U.S. Geological Survey Open-File Report 91-584A, 140 p.

Tukey, J.W., 1977, Exploratory data analysis: Menlo Park, Calif., Addison-Wesley, 688 p.

U.S. Environmental Protection Agency, 1986a, Maximum contaminant levels (subpart B of part 141, National Interim Primary Drinking-Water regulations): U.S. Code of Federal Regulations, Title 40, Parts 100 to 149, revised as of July 1, 1986, p. 524-528.

-1986b, Water pollution control; national primary drinking water regulations; radionuclides; advanced notice of proposed rulemaking: Federal Register, v. 51, no. 189 , p. 34836-34862.

-1991, Water pollution control; national primary drinking water regulations; radionuclides; proposed rule: Federal Register, v. 56, no. 138, p. 33050-33127.

U.S. Geological Survey, 1977, National handbook of recommended methods for water-data acquisition: Office of Water Data Acquisition, 12 numbered chapters.
Welch, A.H., 1994, Geochemistry and quality of ground water in Carson and Eagle Valleys, western Nevada: U.S. Geological Survey Open-File Report 93-33, 99 p.

Welch, A.H., and Lico, M.S., 1988, Mobilization of arsenic in an alluvial-lacustrine aquifer in the arid west, in Ragone, S.E., ed., U.S. Geological Survey Program on Toxic Waste-Ground Water Contamination: U.S. Geological Survey Open-File Report 86-481, p. E13-E18.

Welch, A.H., Lico, M.S., and Hughes, J.L., 1988, Arsenic in ground water of the western United States: Ground Water, v. 26, p. 333-347.

Welch, A.H., and Plume, R.W., 1987, Water-quality assessment of the Carson River ground-water basin, Nevada and California-Project description: U.S. Geological Survey Open-File Report 87-104, 27 p.

Welch, A.H., Plume, R.W., Frick, E.A., and Hughes, J.L., 1989, Ground-water-quality assessment of the Carson River Basin, Nevada and California-Analysis of available water-quality data through 1987: U.S. Geological Survey Open-File Report 89-382, 115 p.

Welch, A.H., Thomas, J.M., and Gunderson, L.C.S., 1990, Distribution and sources of uranium in ground water in the Carson River Basin, western Nevada and eastern California, U.S.A.: Eos, v. 71, no. 43, p. 1305.

Weres, Oleh, Jaouni, Abdur-Rahim, and Tsa, Leon, 1989, The distribution, speciation and geochemical cycling of selenium in a sedimentary environment, Kesterson Reservoir, California, U.S.A.: Applied Geochemistry, v. 4, p. 543-563.

Wershaw, R.L., Fishman, M.J., Grabbe, R.R., and Lowe, L.E., 1987, Methods for the determination of organic substances in water and fluvial sediments: U.S. Geological Survey Techniques of Water-Resources Investigations, Book 5, Chap. A3, 80 p.

Whitney, Rita, 1994, Data on ground-water quality in the Carson River Basin, western Nevada and eastern California, 1987-90: U.S. Geological Survey Open-File Report 94-39, 139 p.

Wigley, T.M.L., Plummer, L.N., and Pearson, F.J., Jr., 1978, Mass transfer and carbon isotope evolution in natural water systems: Geochimica et Cosmochimica Acta, v. 42, p. 1117-1139.

Willden, Ronald, and Speed, R.C., 1974, Geology and mineral deposits of Churchill County, Nevada: Nevada Bureau of Mines Bulletin 83, $95 \mathrm{p}$.

Zaporozec, Alexander, 1972, Graphical interpretation of water-quality data: Ground Water, v. 10, no. 2, p. 32-43. 
APPENDIX

0.64 
Appendix. Summary statistics for the ground-water quality of Dayton, Stagecoach, and Churchill Valleys, Nevada

[Abbreviations and symbols: $\mathrm{mg} / \mathrm{L}$, milligrams per liter; $\mu \mathrm{g} / \mathrm{L}$, micrograms per liter; $\mu \mathrm{S} / \mathrm{cm}$, microsiemens per centimeter at 25 degrees Celsius; $\mathrm{mV}$, millivolts; ${ }^{\circ} \mathrm{C}$, degrees Celsius; --, not determined; <, less than; pCi/L, picocuries per liter; PMC, percent modern carbon; Sr-90/Y-90, strontium-90/yttrium-90. Isotope standards: Deuterium and oxygen relative to Vienna Standard Mean Ocean Water; carbon-13 relative to Pee-Dee Belemnite; sulfur relative to Canyon Diablo meteorite. Uranium in $\mathrm{pCi} / \mathrm{L}$ is calculated from the corresponding uranium values in $\mu \mathrm{g} / \mathrm{L}$ by assuming that the activity ratio of U-234 to U-238 is 1$]$

\begin{tabular}{|c|c|c|c|c|c|c|c|c|c|}
\hline \multicolumn{10}{|c|}{ Upland aquifers } \\
\hline $\begin{array}{c}\text { Constituent } \\
\text { or } \\
\text { parameter }\end{array}$ & $\begin{array}{c}\text { Speclflc } \\
\text { conductance } \\
(\mu \mathrm{S} / \mathrm{cm})\end{array}$ & $\begin{array}{c}\text { pH } \\
\text { (standard } \\
\text { units) }\end{array}$ & $\begin{array}{c}\text { Temperature, } \\
\text { water }\left({ }^{\circ} \mathrm{C}\right)\end{array}$ & $\begin{array}{l}\text { Oxygen, } \\
\text { dissolved } \\
\text { (mg/L) }\end{array}$ & $\begin{array}{l}\text { Calclum, } \\
\text { dlssolved } \\
\text { (mg/L) }\end{array}$ & $\begin{array}{l}\text { Magneslum, } \\
\text { dlssoived } \\
\text { (mg/L) }\end{array}$ & $\begin{array}{c}\text { Sodium, } \\
\text { dlssolved } \\
\text { (mg/L) }\end{array}$ & $\begin{array}{l}\text { Potasslum, } \\
\text { dlssoived } \\
\text { (mg/li) }\end{array}$ & $\begin{array}{l}\text { Bicarbonate, } \\
\text { dlssolved } \\
\text { (mg/L) }\end{array}$ \\
\hline \multicolumn{10}{|l|}{ Number of } \\
\hline samples & $\begin{array}{r}7 \\
360\end{array}$ & $\begin{array}{l}7 \\
66\end{array}$ & $\begin{array}{r}7 \\
13\end{array}$ & 0 & $\begin{array}{r}7 \\
31\end{array}$ & $\begin{array}{r}7 \\
13\end{array}$ & $\begin{array}{r}7 \\
16\end{array}$ & 7 & $\begin{array}{r}7 \\
180\end{array}$ \\
\hline Median & 460 & 7.3 & 15 & -- & 38 & 15 & 27 & $\begin{array}{l}1.3 \\
4\end{array}$ & $\begin{array}{l}100 \\
190\end{array}$ \\
\hline Maximum & 600 & 7.7 & 18 & -- & 81 & 20 & 36 & 10 & 320 \\
\hline $\begin{array}{c}\text { Constituent } \\
\text { or } \\
\text { parameter }\end{array}$ & $\begin{array}{l}\text { Suifate, } \\
\text { dlssolved } \\
\text { (mg/L) }\end{array}$ & $\begin{array}{l}\text { Chlorlde, } \\
\text { dlssolved } \\
\text { (mg/L) }\end{array}$ & $\begin{array}{l}\text { Fluorlde, } \\
\text { dlssoived } \\
\text { (mg/L) }\end{array}$ & $\begin{array}{l}\text { Sllica, } \\
\text { dissolved } \\
\text { (mg/L as } \\
\mathrm{SlO}_{2} \text { ) }\end{array}$ & $\begin{array}{l}\text { Dlssolved } \\
\text { sollds, } \\
\text { sum of } \\
\text { constltu- } \\
\text { ents, } \\
\text { (mg/L) }\end{array}$ & $\begin{array}{c}\text { Carbon, } \\
\text { organlc } \\
\text { dlssoived } \\
\text { (mg/l as C) }\end{array}$ & $\begin{array}{l}\text { Arsenlc } \\
\text { dlssoived } \\
\text { ( } \mu \mathrm{g} / \mathrm{L})\end{array}$ & $\begin{array}{l}\text { Barlum, } \\
\text { dlssolved } \\
\text { ( } \mu \mathrm{g} / \mathrm{L})\end{array}$ & $\begin{array}{l}\text { Boron, } \\
\text { dlssoived } \\
(\mu \mathrm{g} / \mathrm{L})\end{array}$ \\
\hline \multicolumn{10}{|l|}{ Number of } \\
\hline Minimum & 29 & 3.6 & .1 & 18 & 280 & .5 & 14 & 11 & 40 \\
\hline Median & 54 & 8.1 & .2 & 85 & 340 & .5 & 14 & 32 & 40 \\
\hline Maximum & 160 & 11 & .2 & 130 & 410 & .5 & 14 & 92 & 40 \\
\hline $\begin{array}{c}\text { Constituent } \\
\text { or } \\
\text { parameter }\end{array}$ & $\begin{array}{l}\text { Cadmlum, } \\
\text { dlssoived } \\
\text { ( } \mu \mathrm{g} / \mathrm{L})\end{array}$ & $\begin{array}{l}\text { Chromlum, } \\
\text { dlssoived } \\
\text { ( } \mu \mathrm{g} / \mathrm{L})\end{array}$ & $\begin{array}{l}\text { Iron, } \\
\text { dissolved } \\
(\mu \mathrm{g} / \mathrm{L})\end{array}$ & $\begin{array}{l}\text { Lead, } \\
\text { dlssolved } \\
\text { ( } \mu \mathrm{g} / \mathrm{L})\end{array}$ & $\begin{array}{l}\text { Lithlum, } \\
\text { dissolved } \\
\text { ( } \mu \mathrm{g} / \mathrm{L})\end{array}$ & $\begin{array}{c}\text { Manganese, } \\
\text { dlssolved } \\
(\mu g / L)\end{array}$ & $\begin{array}{l}\text { Mercury, } \\
\text { dlssolved } \\
\text { ( } \mu \mathrm{g} / \mathrm{L})\end{array}$ & $\begin{array}{c}\text { Nitrate, } \\
\text { dissolved } \\
\text { (mg/L as } \mathbf{N})\end{array}$ & $\begin{array}{c}\text { Nitrlte, } \\
\text { dissolved } \\
\text { (mg/L as } N \text { ) }\end{array}$ \\
\hline & \multicolumn{9}{|c|}{ Number of } \\
\hline Minimum & $<1$ & $<5$ & $<10$ & $<10$ & 13 & 1 & $<.1$ & $<.1$ & $<.01$ \\
\hline Median & $<1$ & $<5$ & $<10$ & $<10$ & 16 & 4 & .1 & $<.1$ & $<.01$ \\
\hline Maximum & $<1$ & $<5$ & 300 & 20 & 26 & 160 & .2 & $<.1$ & $<.01$ \\
\hline $\begin{array}{c}\text { Constltuent } \\
\text { or } \\
\text { parameter }\end{array}$ & $\begin{array}{c}\text { Ammonla, } \\
\text { dissoived } \\
\text { (mg/L as } N \text { ) }\end{array}$ & $\begin{array}{l}\text { Ortho- } \\
\text { phosphate, } \\
\text { dlssolved } \\
\text { (mg/L as P) }\end{array}$ & $\begin{array}{l}\text { Seienlum, } \\
\text { dlssoived } \\
(\mu \mathrm{g} / \mathrm{L})\end{array}$ & $\begin{array}{l}\text { Sllver, } \\
\text { dlssolved } \\
(\mu \mathrm{g} / \mathrm{L})\end{array}$ & $\begin{array}{c}\text { Carbon } \\
13 / 12 \\
\text { (ratlo } \\
\text { permll) }\end{array}$ & $\begin{array}{l}\text { Carbon-14 } \\
\text { (PMC) }\end{array}$ & $\begin{array}{c}\text { Sulfur } \\
34 / 32 \\
\text { (ratlo } \\
\text { permll) }\end{array}$ & $\begin{array}{l}\text { Tritlum } \\
\text { (pCl/L) }\end{array}$ & $\begin{array}{l}\text { Radon-222, } \\
\text { dlssoived } \\
\text { (pCl/L) }\end{array}$ \\
\hline $\begin{array}{l}\text { Number of } \\
\text { samples }\end{array}$ & 1 & 1 & \multicolumn{7}{|c|}{ Number of } \\
\hline Minimum & .02 & .02 & $<1$ & $<1$ & -- & - & - & 1.3 & 170 \\
\hline Median & .02 & .02 & $<1$ & $<1$ & -- & -- & -- & 1.3 & 250 \\
\hline Maximum & .02 & .02 & $<1$ & $<1$ & -- & -- & -- & 1.3 & 970 \\
\hline $\begin{array}{c}\text { Constltuent } \\
\text { or } \\
\text { parameter }\end{array}$ & $\begin{array}{l}\text { Radlum-226, } \\
\text { dlssolved } \\
\text { (pCl/L) }\end{array}$ & $\begin{array}{l}\text { Radlum- } \\
228, \\
\text { dissolved } \\
\text { (pCl/L) }\end{array}$ & $\begin{array}{l}\text { Uranlum, } \\
\text { dlssolved } \\
(\mu \mathrm{g} / \mathrm{L})\end{array}$ & $\begin{array}{l}\text { Uranlum, } \\
\text { dlssolved } \\
\text { (pCl/L) }\end{array}$ & $\begin{array}{l}\text { Gross } \\
\text { alpha, } \\
\text { dlssolved } \\
\text { (pCl/L } \\
\text { as U) }\end{array}$ & $\begin{array}{l}\text { Gross beta, } \\
\text { dissolved } \\
\text { (pCl/L as } \\
\text { Sr-90/Y-90) }\end{array}$ & & & \\
\hline \multicolumn{9}{|l|}{ Number of } & \\
\hline Minimum & .04 & -- & 1.2 & .81 & .27 & 4 & & & \\
\hline Median & .04 & -- & 100 & 70 & .27 & 4 & & & \\
\hline Maximum & .05 & -- & 210 & 140 & .27 & 4 & & & \\
\hline
\end{tabular}


Appendix. Summary statistics for the ground-water quality of Dayton, Stagecoach, and Churchill Valleys, Nevada-Continued

\begin{tabular}{|c|c|c|c|c|c|c|c|c|c|}
\hline \multicolumn{10}{|c|}{ Shallow aquifers } \\
\hline $\begin{array}{l}\text { Constltuent } \\
\text { or } \\
\text { parameter }\end{array}$ & $\begin{array}{c}\text { Speclfic } \\
\text { conductance } \\
(\mu \mathrm{S} / \mathrm{cm})\end{array}$ & $\begin{array}{c}\mathrm{pH} \\
\text { (standard } \\
\text { units) }\end{array}$ & $\begin{array}{c}\text { Temperature, } \\
\text { water }\left({ }^{\circ} \mathrm{C}\right)\end{array}$ & $\begin{array}{l}\text { Oxygen, } \\
\text { dlssolved } \\
\text { (mg/L) }\end{array}$ & $\begin{array}{l}\text { Calclum, } \\
\text { dlssolved } \\
\text { (mg/L) }\end{array}$ & $\begin{array}{l}\text { Magnesium, } \\
\text { dlssolved } \\
\text { (mg/L) }\end{array}$ & $\begin{array}{l}\text { Sodlum, } \\
\text { dlssolved } \\
\text { (mg/L) }\end{array}$ & $\begin{array}{l}\text { Potassium, } \\
\text { dlssolved } \\
\text { (mg/L) }\end{array}$ & $\begin{array}{l}\text { Blcarbonate, } \\
\text { dlssolved } \\
\text { (mg/L) }\end{array}$ \\
\hline $\begin{array}{l}\text { Number of } \\
\text { samples } \\
\text { Minimum } \\
\text { Median } \\
\text { Maximum }\end{array}$ & $\begin{array}{r}5 \\
430 \\
470 \\
1,100\end{array}$ & $\begin{array}{l}5 \\
6.8 \\
6.8 \\
7.0\end{array}$ & $\begin{array}{r}5 \\
14 \\
16 \\
17\end{array}$ & $\begin{array}{r}3 \\
<1 \\
<1 \\
<1\end{array}$ & $\begin{array}{r}3 \\
30 \\
55 \\
100\end{array}$ & $\begin{array}{l}3 \\
6.2 \\
8.4 \\
32\end{array}$ & $\begin{array}{r}3 \\
34 \\
55 \\
110\end{array}$ & $\begin{array}{l}3 \\
2.7 \\
3.8 \\
6.1\end{array}$ & $\begin{array}{r}5 \\
140 \\
150 \\
300\end{array}$ \\
\hline $\begin{array}{l}\text { Constltuent } \\
\text { or } \\
\text { parameter }\end{array}$ & $\begin{array}{l}\text { Sulfate, } \\
\text { dlssolved } \\
\text { (mg/L) }\end{array}$ & $\begin{array}{l}\text { Chlorlde, } \\
\text { dlssolved } \\
\text { (mg/L) }\end{array}$ & $\begin{array}{l}\text { Fluoride, } \\
\text { dlssolved } \\
\text { (mg/L) }\end{array}$ & $\begin{array}{l}\text { Sillca, } \\
\text { dissolved } \\
\text { (mg/las as } \\
\left.\mathrm{SiO}_{2}\right)\end{array}$ & $\begin{array}{l}\text { Dlssolved } \\
\text { sollds, } \\
\text { sum of } \\
\text { constltu- } \\
\text { ents, } \\
\text { (mg/L) }\end{array}$ & $\begin{array}{l}\text { Carbon, } \\
\text { organic } \\
\text { dissolved } \\
\text { (mgll as C) }\end{array}$ & $\begin{array}{c}\text { Arsenlc } \\
\text { dlssolved } \\
(\mu g / L)\end{array}$ & $\begin{array}{l}\text { Barium, } \\
\text { dissoived } \\
(\mu g / L)\end{array}$ & $\begin{array}{l}\text { Boron, } \\
\text { dlssolved } \\
(\mu g / L)\end{array}$ \\
\hline $\begin{array}{l}\text { Number of } \\
\text { samples } \\
\text { Minimum } \\
\text { Median } \\
\text { Maximum }\end{array}$ & $\begin{array}{r}3 \\
81 \\
82 \\
320\end{array}$ & $\begin{array}{r}3 \\
12 \\
14 \\
39\end{array}$ & $\begin{array}{r}3 \\
.3 \\
.5 \\
1.1\end{array}$ & $\begin{array}{r}3 \\
30 \\
30 \\
38\end{array}$ & $\begin{array}{r}3 \\
290 \\
300 \\
780\end{array}$ & $\begin{array}{l}3 \\
2.3 \\
2.4 \\
2.8\end{array}$ & $\begin{array}{r}4 \\
3 \\
16 \\
25\end{array}$ & $\begin{array}{r}3 \\
35 \\
48 \\
51\end{array}$ & $\begin{array}{r}3 \\
210 \\
220 \\
500\end{array}$ \\
\hline $\begin{array}{c}\text { Constltuent } \\
\text { or } \\
\text { parameter }\end{array}$ & $\begin{array}{l}\text { Cadmlum, } \\
\text { dlssolved } \\
(\mu g / L)\end{array}$ & $\begin{array}{c}\text { Chromlum, } \\
\text { dlssolved } \\
(\mu g / L)\end{array}$ & $\begin{array}{l}\text { Iron, } \\
\text { dissolved } \\
(\mu g / L)\end{array}$ & $\begin{array}{l}\text { Lead, } \\
\text { dlssolved } \\
(\mu \mathrm{g} / \mathrm{L})\end{array}$ & $\begin{array}{l}\text { Llthlum, } \\
\text { dissolved } \\
(\mu g / L)\end{array}$ & $\begin{array}{c}\text { Manganese, } \\
\text { dissoived } \\
(\mu g / L)\end{array}$ & $\begin{array}{l}\text { Mercury, } \\
\text { dlssolved } \\
(\mu g / L)\end{array}$ & $\begin{array}{c}\text { Nitrate, } \\
\text { dlssolved } \\
\text { (mg/L as N) }\end{array}$ & $\begin{array}{c}\text { Nitrite, } \\
\text { dlssolved } \\
\text { (mg/L as N) }\end{array}$ \\
\hline $\begin{array}{l}\text { Number of } \\
\text { samples } \\
\text { Minimum } \\
\text { Median } \\
\text { Maximum }\end{array}$ & $\begin{array}{r}3 \\
<1 \\
<1 \\
1\end{array}$ & $\begin{array}{r}3 \\
<5 \\
<5 \\
<5\end{array}$ & \begin{tabular}{l}
\multicolumn{1}{c}{5} \\
$<.5$ \\
310 \\
370
\end{tabular} & $\begin{array}{r}3 \\
<10 \\
<10 \\
<10\end{array}$ & $\begin{array}{r}3 \\
9 \\
31 \\
45\end{array}$ & $\begin{array}{r}3 \\
36 \\
1,900 \\
2,300\end{array}$ & $\begin{array}{l}3 \\
<.1 \\
<.1 \\
<.1\end{array}$ & $\begin{array}{l}3 \\
<.1 \\
<.1 \\
<.1\end{array}$ & $\begin{array}{l}3 \\
<.01 \\
<.01 \\
<.01\end{array}$ \\
\hline $\begin{array}{l}\text { Constltuent } \\
\text { or } \\
\text { parameter }\end{array}$ & $\begin{array}{l}\text { Ammonla, } \\
\text { dlssolved } \\
\text { (mg/L as N) }\end{array}$ & $\begin{array}{c}\text { Ortho- } \\
\text { phosphate, } \\
\text { dlssolved } \\
\text { (mg/L as P) }\end{array}$ & $\begin{array}{l}\text { Selenlum, } \\
\text { dlssolved } \\
(\mu g / L)\end{array}$ & $\begin{array}{l}\text { Sllver, } \\
\text { dlssolved } \\
(\mu g / L)\end{array}$ & $\begin{array}{c}\text { Carbon } \\
13 / 12 \\
\text { (ratlo } \\
\text { permil) }\end{array}$ & $\begin{array}{l}\text { Carbon-14 } \\
\text { (PMC) }\end{array}$ & $\begin{array}{c}\text { Sulfur } \\
34 / 32 \\
\text { (ratlo } \\
\text { permli) }\end{array}$ & $\begin{array}{l}\text { TrItlum } \\
\text { (pCl/L) }\end{array}$ & $\begin{array}{l}\text { Radon-222, } \\
\text { dlssolved } \\
\text { (pCl/L) }\end{array}$ \\
\hline $\begin{array}{l}\text { Number of } \\
\text { samples } \\
\text { Minimum } \\
\text { Median } \\
\text { Maximum }\end{array}$ & $\begin{array}{l}3 \\
.03 \\
.04 \\
.21\end{array}$ & $\begin{array}{l}3 \\
.03 \\
.16 \\
.30\end{array}$ & $\begin{array}{r}3 \\
<1 \\
<1 \\
<1\end{array}$ & $\begin{array}{r}3 \\
<1 \\
<1 \\
<1\end{array}$ & $\begin{array}{l}0 \\
-- \\
-- \\
--\end{array}$ & $\begin{array}{l}0 \\
-- \\
-- \\
--\end{array}$ & $\begin{array}{l}0 \\
-- \\
-- \\
--\end{array}$ & $\begin{array}{l}0 \\
-- \\
-- \\
--\end{array}$ & $\begin{array}{r}3 \\
310 \\
340 \\
480\end{array}$ \\
\hline $\begin{array}{l}\text { Constltuent } \\
\text { or } \\
\text { parameter }\end{array}$ & $\begin{array}{l}\text { Radlum-226, } \\
\text { dlssolved } \\
\text { (pCi/L) }\end{array}$ & $\begin{array}{l}\text { Radlum- } \\
\text { 228, } \\
\text { dlssolved } \\
\text { (pCI/L) }\end{array}$ & $\begin{array}{l}\text { Uranlum, } \\
\text { dlssolved } \\
(\mu g / L)\end{array}$ & $\begin{array}{l}\text { Uranlum, } \\
\text { dlssolved } \\
\text { (pCl/L) }\end{array}$ & $\begin{array}{l}\text { Gross } \\
\text { alpha, } \\
\text { dlssolved } \\
\text { (pCl/L } \\
\text { as U) }\end{array}$ & $\begin{array}{c}\text { Gross beta, } \\
\text { dlssoived } \\
\text { (pCl/L as } \\
\text { sr-90/Y-90) }\end{array}$ & & & \\
\hline $\begin{array}{l}\text { Number of } \\
\text { samples } \\
\text { Minimum } \\
\text { Median } \\
\text { Maximum }\end{array}$ & $\begin{array}{l}0 \\
-- \\
-- \\
--\end{array}$ & $\begin{array}{l}0 \\
-- \\
-- \\
--\end{array}$ & $\begin{array}{c}3 \\
.7 \\
1.1 \\
28\end{array}$ & $\begin{array}{r}3 \\
.47 \\
.75\end{array}$ & $\begin{array}{l}4 \\
.95 \\
1.5 \\
16\end{array}$ & $\begin{array}{l}4 \\
3 \\
4.3 \\
20\end{array}$ & & & \\
\hline
\end{tabular}


Appendlx. Summary statistics for the ground-water quality of Dayton, Stagecoach, and Churchill Valleys, Nevada-Continued

Principal aquifers

\begin{tabular}{|c|c|c|c|c|c|c|c|c|c|}
\hline $\begin{array}{c}\text { Constituent } \\
\text { or } \\
\text { parameter }\end{array}$ & $\begin{array}{c}\text { Speclfic } \\
\text { conductance } \\
(\mu \mathrm{S} / \mathrm{cm})\end{array}$ & $\begin{array}{c}\mathrm{pH} \\
\text { (standard } \\
\text { unlts) }\end{array}$ & $\begin{array}{c}\text { Temperature, } \\
\text { water }\left({ }^{\circ} \mathrm{C}\right)\end{array}$ & $\begin{array}{l}\text { Oxygen, } \\
\text { dissolved } \\
\text { (mg/L) }\end{array}$ & $\begin{array}{l}\text { Calclum, } \\
\text { dlssolved } \\
\text { (mg/L) }\end{array}$ & $\begin{array}{l}\text { Magneslum, } \\
\text { dlssolved } \\
\text { (mg/L) }\end{array}$ & $\begin{array}{l}\text { Sodlum, } \\
\text { dlssolved } \\
\text { (mg/L) }\end{array}$ & $\begin{array}{l}\text { Potasslum, } \\
\text { dissolved } \\
\text { (mg/L) }\end{array}$ & $\begin{array}{l}\text { Blcarbonate, } \\
\text { dlssolved } \\
\text { (mg/L) }\end{array}$ \\
\hline $\begin{array}{l}\text { Number of } \\
\text { samples }\end{array}$ & 49 & 49 & 48 & 29 & 48 & 48 & 48 & 48 & 49 \\
\hline Minimum & 270 & 7.0 & 12 & $<1$ & 18 & .16 & 14 & 1.9 & 71 \\
\hline 25 th percentile & 440 & 7.4 & 16 & $<1$ & 34 & 16 & 31 & 4.3 & 140 \\
\hline Median & 570 & 7.6 & 17 & 4.4 & 50 & 24 & 41 & 5.7 & 160 \\
\hline 75th percentile & 850 & 7.8 & 19 & 6.2 & 79 & 63 & 60 & 7.8 & 200 \\
\hline Maximum & 2,400 & 8.3 & 24 & 7.3 & 400 & & 440 & 17 & 350 \\
\hline $\begin{array}{c}\text { Constituent } \\
\text { or } \\
\text { parameter }\end{array}$ & $\begin{array}{l}\text { Sulfate, } \\
\text { dlssolved } \\
\text { (mg/L) }\end{array}$ & $\begin{array}{l}\text { Chloride, } \\
\text { dlssolved } \\
\text { (mg/L) }\end{array}$ & $\begin{array}{l}\text { Fluorlde, } \\
\text { dlssolved } \\
\text { (mg/L) }\end{array}$ & $\begin{array}{l}\text { Sliica, } \\
\text { dlssolved } \\
\text { (mg/L as } \\
\left.\mathrm{SIO}_{2}\right)\end{array}$ & $\begin{array}{l}\text { Dlssolved } \\
\text { solids, } \\
\text { sum of } \\
\text { constltu- } \\
\text { ents, } \\
\text { (mg/L) }\end{array}$ & $\begin{array}{c}\text { Carbon, } \\
\text { organlc } \\
\text { dlssolved } \\
\text { (mg/L as C) }\end{array}$ & $\begin{array}{c}\text { Arsenlc } \\
\text { dissolved } \\
(\mu g / L)\end{array}$ & $\begin{array}{l}\text { Barlum, } \\
\text { dlssolved } \\
(\mu g / L)\end{array}$ & $\begin{array}{l}\text { Boron, } \\
\text { dissolved } \\
(\mu g / L)\end{array}$ \\
\hline $\begin{array}{l}\text { Number of } \\
\text { samples }\end{array}$ & 48 & 48 & 48 & 48 & 48 & 29 & 29 & 48 & 29 \\
\hline Minimum & 25 & 6.5 & $<.1$ & 24 & 200 & .2 & $<1$ & 10 & 30 \\
\hline 25 th percentile & 56 & 11 & .2 & 48 & 330 & .3 & 2.5 & 30 & 70 \\
\hline Median & 98 & 15 & .2 & 60 & 400 & .4 & 7 & 51 & 150 \\
\hline 75th percentile & 210 & 26 & .3 & 80 & 550 & .65 & 13 & 70 & 270 \\
\hline Maximum & 1,100 & 170 & 2.9 & 140 & 1,700 & 2.1 & 110 & 140 & 3,200 \\
\hline $\begin{array}{c}\text { Constltuent } \\
\text { or } \\
\text { parameter }\end{array}$ & $\begin{array}{l}\text { Cadmlum, } \\
\text { dlssolved } \\
(\mu \mathrm{g} / L)\end{array}$ & $\begin{array}{l}\text { Chromium, } \\
\text { dlssolved } \\
(\mu g / L)\end{array}$ & $\begin{array}{l}\text { Iron, } \\
\text { dlssolved } \\
(\mu g / L)\end{array}$ & $\begin{array}{l}\text { Lead, } \\
\text { dlssolved } \\
(\mu \mathrm{g} / L)\end{array}$ & $\begin{array}{l}\text { Lithlum, } \\
\text { dlssolved } \\
(\mu g / L)\end{array}$ & $\begin{array}{l}\text { Manganese, } \\
\text { dlssolved } \\
(\mu g / L)\end{array}$ & $\begin{array}{l}\text { Mercury, } \\
\text { dissolved } \\
(\mu g / L)\end{array}$ & $\begin{array}{c}\text { Nitrate, } \\
\text { dlssolved } \\
\text { (mg/l as N) }\end{array}$ & $\begin{array}{c}\text { Nitrilte, } \\
\text { dissolved } \\
\text { (mg/L as N) }\end{array}$ \\
\hline $\begin{array}{l}\text { Number of } \\
\text { samples }\end{array}$ & 48 & 29 & 49 & 48 & 48 & 48 & 48 & 29 & 29 \\
\hline Minimum & $<1$ & $<5$ & $<10$ & $<10$ & 5 & $<3$ & $<.1$ & $<.1$ & $<.01$ \\
\hline 25 th percentile & $<1$ & $<5$ & $<10$ & $<10$ & 12 & $<3$ & $<.1$ & $<.1$ & $<.01$ \\
\hline Median & $<1$ & $<5$ & 19 & $<10$ & 18 & 3.5 & $<.1$ & 1.1 & $<.01$ \\
\hline 75th percentile & $<1$ & $<5$ & 76 & 10 & 27 & 76 & $<.1$ & 2.4 & $<.01$ \\
\hline Maximum & 1 & $<15$ & 3,900 & 20 & 420 & 2,800 & .6 & 5.6 & .02 \\
\hline $\begin{array}{c}\text { Constltuent } \\
\text { or } \\
\text { parameter }\end{array}$ & $\begin{array}{c}\text { Ammonla, } \\
\text { dlssolved } \\
\text { (mg/L as } N \text { ) }\end{array}$ & $\begin{array}{c}\text { Ortho- } \\
\text { phosphate, } \\
\text { dlssolved } \\
\text { (mg/L as P) }\end{array}$ & $\begin{array}{l}\text { Selenlum, } \\
\text { dlssolved } \\
(\mu g / L)\end{array}$ & $\begin{array}{l}\text { Sllver, } \\
\text { dlssolved } \\
(\mu g / L)\end{array}$ & $\begin{array}{c}\text { Carbon } \\
13 / 12 \\
\text { (ratlo } \\
\text { permil) }\end{array}$ & $\begin{array}{c}\text { Carbon-14 } \\
\text { (PMC) }\end{array}$ & $\begin{array}{c}\text { Sulfur } \\
34 / 32 \\
\text { (ratio } \\
\text { permII) }\end{array}$ & $\begin{array}{l}\text { Tritlum } \\
\text { (pCl/L) }\end{array}$ & $\begin{array}{l}\text { Radon-222, } \\
\text { dissolved } \\
\text { (pCl/L) }\end{array}$ \\
\hline $\begin{array}{l}\text { Number of } \\
\text { samples }\end{array}$ & 29 & 29 & 29 & 28 & 22 & 18 & 19 & 20 & 28 \\
\hline Minimum & $<.01$ & $<.01$ & $<1$ & $<1$ & -15.1 & 3.3 & -15.9 & $<.3$ & 150 \\
\hline 25 th percentile & $<.01$ & $<.01$ & $<1$ & $<1$ & -13.0 & 27.9 & -.2 & $<.3$ & 370 \\
\hline Median & $<.01$ & .02 & $<1$ & $<1$ & -11.6 & 52.3 & 5.5 & $<.3$ & 660 \\
\hline 75th percentile & $<.01$ & .05 & 1.5 & $<1$ & -10.2 & 91.5 & 11.0 & 3.4 & 880 \\
\hline Maximum & .02 & 1.6 & 12 & 2 & -8.0 & 109.2 & 15.2 & 93 & 1,800 \\
\hline $\begin{array}{c}\text { Constltuent } \\
\text { or } \\
\text { parameter }\end{array}$ & $\begin{array}{l}\text { Radlum-226, } \\
\text { dlssoived } \\
\text { (pCl/L) }\end{array}$ & $\begin{array}{l}\text { Radlum- } \\
\text { 228, } \\
\text { dlssolved } \\
\text { (pCl/L) }\end{array}$ & $\begin{array}{l}\text { Uranlum, } \\
\text { dissolved } \\
(\mu g / L)\end{array}$ & $\begin{array}{l}\text { Uranlum, } \\
\text { dissolved } \\
\text { (pCl/L) }\end{array}$ & $\begin{array}{l}\text { Gross } \\
\text { alpha, } \\
\text { dlssolved } \\
\text { (pCl/L } \\
\text { as U) }\end{array}$ & $\begin{array}{l}\text { Gross } \\
\text { beta, } \\
\text { dlssolved } \\
\text { (pCI/L as } \\
\text { Sr-90/N-90) }\end{array}$ & & & \\
\hline $\begin{array}{l}\text { Number of } \\
\text { samples }\end{array}$ & 1 & 1 & 21 & 21 & 29 & 29 & & & \\
\hline Minimum & .1 & 1 & $<.4$ & $<.27$ & .27 & 3.5 & & & \\
\hline 25 th percentile & -- & -- & 1.5 & 1 & 1.2 & 5.3 & & & \\
\hline Median & .1 & 1 & 2.2 & 1.5 & 1.8 & 7.6 & & & \\
\hline 75th percentile & -- & - & 5.9 & 4 & 4.3 & 9.6 & & & \\
\hline Maximum & .1 & 1 & 23 & 16 & 21 & 21 & & & \\
\hline
\end{tabular}

